Prepared in cooperation with the West Virginia Bureau for Public Health, Office of Environmental Health Services

\title{
Estimation of Traveltime and Longitudinal Dispersion in Streams in West Virginia
}

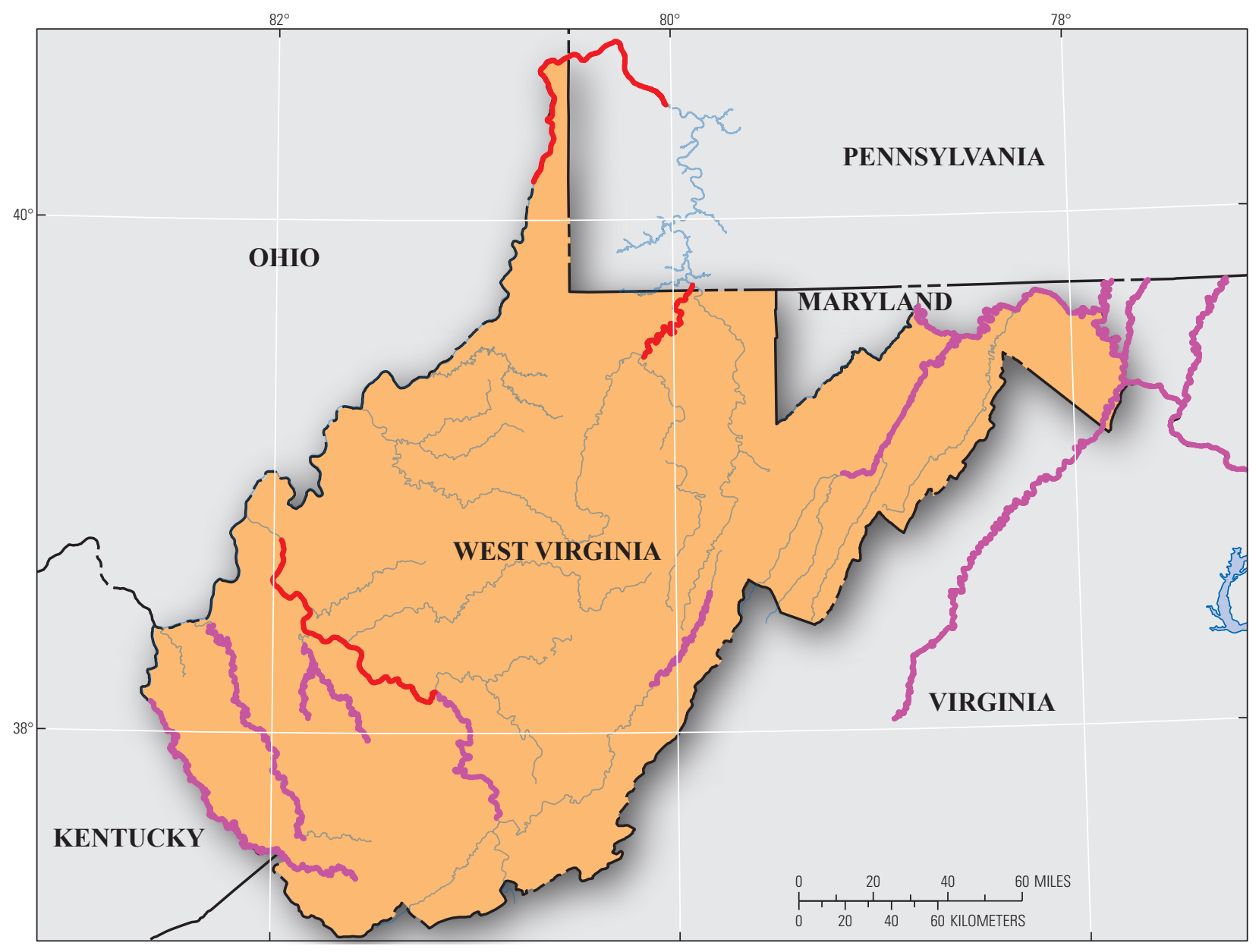

Scientific Investigations Report 2013-5182 
Cover. Stream reaches in and near West Virginia where traveltime and dispersion have been measured, 1964-85. Free-flowing stream reaches with data shown in purple. Regulated stream reaches with data shown in red. 


\section{Estimation of Traveltime and Longitudinal Dispersion in Streams in West Virginia}

By Jeffrey B. Wiley and Terence Messinger

Prepared in cooperation with the

West Virginia Bureau for Public Health, Office of Environmental Health Services

Scientific Investigations Report 2013-5182 


\title{
U.S. Department of the Interior SALLY JEWELL, Secretary
}

\section{U.S. Geological Survey Suzette M. Kimball, Acting Director}

\author{
U.S. Geological Survey, Reston, Virginia: 2013
}

For more information on the USGS - the Federal source for science about the Earth, its natural and living resources, natural hazards, and the environment, visit http://www.usgs.gov or call 1-888-ASK-USGS.

For an overview of USGS information products, including maps, imagery, and publications, visit http://www.usgs.gov/pubprod

To order this and other USGS information products, visit http://store.usgs.gov

Any use of trade, firm, or product names is for descriptive purposes only and does not imply endorsement by the U.S. Government.

Although this information product, for the most part, is in the public domain, it also may contain copyrighted materials as noted in the text. Permission to reproduce copyrighted items must be secured from the copyright owner.

Suggested citation:

Wiley, J.B., and Messinger, Terence, 2013, Estimation of traveltime and longitudinal dispersion in streams in West Virginia: U.S. Geological Survey Scientific Investigations Report 2013-5182, 62 p., http://doi.dx.org/10.3133/ sir20135182.

ISSN 2328-0328 (online) 


\section{Contents}

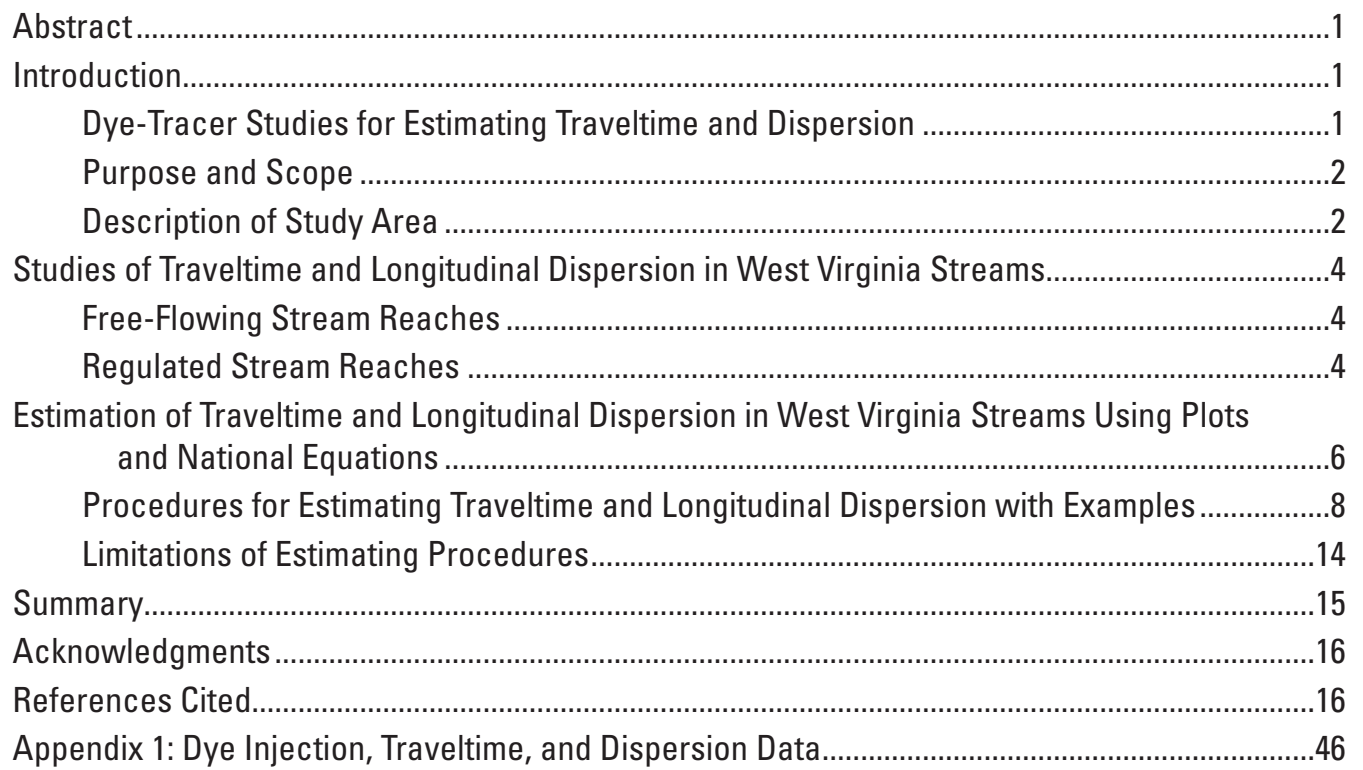




\section{Figures}

1. Map showing Appalachian Plateaus, Valley and Ridge, and Blue Ridge Physiographic Provinces, and Climatic Divide in West Virginia...

2. Map showing stream reaches in and near West Virginia where traveltime and dispersion have been measured, 1964-85, and selected locations discussed in examples.

3. A, Graph showing traveltime and dispersion characteristics for selected reaches, and $B$, map showing location of the reaches of the Tug Fork of the Big Sandy River, West Virginia

4. A, Graph showing traveltime and dispersion characteristics of selected reaches, and $B$, map showing location of the reaches of the Guyandotte River,

West Virginia

5. A, Graph showing traveltime and dispersion characteristics of selected reaches of the Big Coal River, and $B$, map showing location of the reaches of the Big Coal River, Little Coal River, and Coal River, West Virginia

6. Graph showing traveltime and dispersion characteristics of selected reaches of the Little Coal River, West Virginia

7. Graph showing traveltime and dispersion characteristics of selected reaches of the Coal River, West Virginia.

8. A, Graph showing traveltime and dispersion characteristics of selected reaches, and $B$, map showing location of the reaches of the New River, West Virginia.. .26

9. A, Graph showing traveltime and dispersion characteristics of selected reaches, and $B$, map showing location of the reaches of the Greenbrier River, West Virginia.....28

10. $A$, Graph showing traveltime and dispersion characteristics of selected reaches, and $B$, map showing location of the reaches of the North Branch Potomac and Potomac Rivers upstream from Dam Number 5, Maryland, Virginia, and West Virginia..

11. A, Graph showing traveltime and dispersion characteristics of selected reaches, and $B$, map showing locations of the reaches of the Potomac River downstream from Fort Frederick, Maryland, Virginia, and West Virginia

12. A, Graph showing traveltime and dispersion characteristics of selected reaches, and $B$, map showing locations of the reaches of the South Branch Potomac River, West Virginia

13. Graph showing traveltime and dispersion characteristics of selected reaches of the South Fork Shenandoah and Shenandoah Rivers, Virginia and West Virginia, $A$, up to 90 miles downstream from Waynesboro, Virginia, $B$, more than 90 miles downstream from Waynesboro, Virginia, and $C$, map showing location of the reaches

14. Graph showing traveltime and dispersion characteristics of the Kanawha River, West Virginia, $A$, up to 50 miles downstream from the Elkem Metals Aqueduct Forebay, $B$, more than 50 miles downstream from the Elkem Metals Aqueduct Forebay, and $C$, map showing location of the reaches.

15. A, Graph showing traveltime characteristics of selected reaches, and $B$, map showing location of the reaches of the Monongahela River, Pennsylvania and West Virginia. 
16. A, Graph showing traveltime and dispersion characteristics of selected reaches, and $B$, map showing location of the reaches of the Ohio River, Pennsylvania, Ohio, and West Virginia.

17. Graph showing unit-peak concentrations as a function of traveltime for measurements made in and near West Virginia, 1964-1985, with equation 3 plotted for two values of $Q / Q_{a}$

18. Graph showing velocity of the peak concentration as a function of dimensionless drainage area, dimensionless streamflow, dimensionless slope, local streamflow, and drainage area for measurements made in and near West Virginia, 1964-1985. .......9

19. Traveltime and dispersion characteristics for selected reaches of the Tug Fork of the Big Sandy River, West Virginia, and selected characteristics used in estimating traveltime and dispersion of a hypothetical spill discussed in example 1 of the report.

\section{Conversion Factors, Datums, and Abbreviations}

\begin{tabular}{|c|c|c|}
\hline Multiply & By & To obtain \\
\hline \multicolumn{3}{|c|}{ Length } \\
\hline inch (in) & 2.54 & centimeter $(\mathrm{cm})$ \\
\hline inch (in) & 25.4 & millimeter $(\mathrm{mm})$ \\
\hline foot $(\mathrm{ft})$ & 0.3048 & meter $(\mathrm{m})$ \\
\hline mile $(\mathrm{mi})$ & 1.609 & kilometer $(\mathrm{km})$ \\
\hline \multicolumn{3}{|c|}{ Area } \\
\hline acre & 4,047 & square meter $\left(\mathrm{m}^{2}\right)$ \\
\hline square foot $\left(\mathrm{ft}^{2}\right)$ & 0.09290 & square meter $\left(\mathrm{m}^{2}\right)$ \\
\hline square mile $\left(\mathrm{mi}^{2}\right)$ & 2.590 & square kilometer $\left(\mathrm{km}^{2}\right)$ \\
\hline \multicolumn{3}{|c|}{ Volume } \\
\hline gallon (gal) & 3.785 & liter (L) \\
\hline gallon (gal) & 0.003785 & cubic meter $\left(\mathrm{m}^{3}\right)$ \\
\hline cubic foot $\left(\mathrm{ft}^{3}\right)$ & 0.02832 & cubic meter $\left(\mathrm{m}^{3}\right)$ \\
\hline \multicolumn{3}{|c|}{ Flow rate } \\
\hline cubic foot per second $\left(\mathrm{ft}^{3} / \mathrm{s}\right)$ & 0.02832 & cubic meter per second $\left(\mathrm{m}^{3} / \mathrm{s}\right)$ \\
\hline \multicolumn{3}{|c|}{ Mass } \\
\hline ounce, avoirdupois (oz) & $28,349,523$ & microgram $(\mu \mathrm{g})$ \\
\hline pound, avoirdupois (lb) & 0.4536 & kilogram $(\mathrm{kg})$ \\
\hline
\end{tabular}

Vertical coordinate information is referenced to the North American Vertical Datum of 1988 (NAVD 88).

Horizontal coordinate information is referenced to the North American Datum of 1983 (NAD 83).

Altitude, as used in this report, refers to distance above the vertical datum. 


\section{Abbreviations}

C

$C_{p} \quad$ peak concentration

$C_{\text {up }} \quad$ unit peak concentration

$\mathrm{D}^{\prime}$ a dimensionless drainage area

$\mathrm{D}_{\mathrm{a}} \quad$ drainage area

GIS geographic information system

$\mathrm{M}_{\mathrm{i}} \quad$ injection mass

$\mathrm{M}_{r} \quad$ recovery mass

NAVD 88 North American Vertical Datum of 1988

ORSANCO Ohio River Valley Water Sanitation Commission

0 streamflow

$\mathrm{O}_{\mathrm{a}}^{\prime} \quad$ dimensionless flow

$\mathrm{O}_{\mathrm{a}}$ mean annual streamflow

RMSE root mean square error

$\mathrm{R}_{\mathrm{r}} \quad$ recovery ratio

$S$ slope

$\mathrm{T}_{\mathrm{d}} 10$ time elapsed until solute concentration is 10 percent of peak concentration

$T_{1} \quad$ traveltime of leading edge

$T_{p} \quad$ traveltime of peak concentration

USGS U.S. Geological Survey

$\mathrm{V}_{\mathrm{mp}} \quad$ maximum probable velocity

$\mathrm{V}_{\mathrm{p}} \quad$ peak velocity 


\title{
Estimation of Traveltime and Longitudinal Dispersion in Streams in West Virginia
}

\author{
By Jeffrey B. Wiley and Terence Messinger
}

\section{Abstract}

Traveltime and dispersion data are important for understanding and responding to spills of contaminants in waterways. The U.S. Geological Survey (USGS), in cooperation with West Virginia Bureau for Public Health, Office of Environmental Health Services, compiled and evaluated traveltime and longitudinal dispersion data representative of many West Virginia waterways. Traveltime and dispersion data were not available for streams in the northwestern part of the State. Compiled data were compared with estimates determined from national equations previously published by the USGS. The evaluation summarized procedures and examples for estimating traveltime and dispersion on streams in West Virginia.

National equations developed by the USGS can be used to predict traveltime and dispersion for streams located in West Virginia, but the predictions will be less accurate than those made with graphical interpolation between measurements. National equations for peak concentration, velocity of the peak concentration, and traveltime of the leading edge had root mean square errors (RMSE) of $0.426 \log$ units (127 percent), 0.505 feet per second (ft/s), and 3.78 hours (h). West Virginia data fit the national equations for peak concentration, velocity of the peak concentration, and traveltime of the leading edge with RMSE of 0.139 log units (38 percent), $0.630 \mathrm{ft} / \mathrm{s}$, and $3.38 \mathrm{~h}$, respectively. The national equation for maximum possible velocity of the peak concentration exceeded 99 percent and 100 percent of observed values from the national data set and West Virginia-only data set, respectively. No RMSE was reported for time of passage of a dye cloud, as estimated using the national equation; however, the estimates made using the national equations had a root mean square error of $3.82 \mathrm{~h}$ when compared to data gathered for this study.

Traveltime and dispersion estimates can be made from the plots of traveltime as a function of streamflow and location for streams with plots available, but estimates can be made using the national equations for streams without plots. The estimating procedures are not valid for regulated stream reaches that were not individually studied or streamflows outside the limits studied.
Rapidly changing streamflow and inadequate mixing across the stream channel affect traveltime and dispersion, and reduce the accuracy of estimates. Increases in streamflow typically result in decreases in the peak concentration and traveltime of the peak concentration. Decreases in streamflow typically result in increases in the peak concentration and traveltime of the peak concentration. Traveltimes will likely be less than those determined using the estimating equations and procedures if the spill is in the center of the stream, and traveltimes will likely be greater than those determined using the estimating equations and procedures if the spill is near the streambank.

\section{Introduction}

Traveltime and dispersion data are needed for streams in West Virginia to protect public water-supply intakes from possible contamination by hazardous materials introduced intentionally or from accidental spills. Accidental spills of hazardous materials into streams can occur along transportation corridors from roads and railroads that parallel or intersect rivers, from transportation on the rivers themselves, and from areas adjacent to rivers where hazardous materials are manufactured, stored, or handled. Information on the traveltime from a point on a stream where a hazardous material might be introduced to a public water-supply intake would allow the water utility to minimize the risk of contaminating the water supply and maximize service to customers. A study was conducted by the U.S. Geological Survey (USGS) in cooperation with the West Virginia Bureau for Public Health, Office of Environmental Health Services, to determine appropriate methods for estimating the traveltime and dispersion of a dye tracer introduced into selected streams in West Virginia.

\section{Dye-Tracer Studies for Estimating Traveltime and Dispersion}

Measurements of traveltime and dispersion of a conservative-dye tracer have been used to estimate the movement of 
water and waterborne solutes in many rivers. Measurement techniques are well documented (Kilpatrick and Wilson, 1989; Hubbard and others, 1982). Methods of water-sample analysis for dyes have been described by Wilson and others (1986). Usually, a fluorescent dye is injected into the river. Water samples are then collected at various locations downstream, beyond the distance required for horizontal and vertical mixing. Results are typically reported as traveltime for the leading edge, peak concentration, and trailing edge of the dye cloud. Longitudinal dispersion, or the elongation of the dye cloud longitudinally, is often shown as time-concentration curves (Hubbard and others, 1982). Details of presentation for both traveltime and dispersion have varied greatly.

Jobson (1996) presented national equations for estimating the traveltime and longitudinal dispersion of a solute in a stream on the basis of results of dye studies conducted by the USGS on many different streams throughout the United States. The national equations were developed from a diverse set of stream reaches with drainage areas ranging from 3.86 to $1,120,000$ square miles $\left(\mathrm{mi}^{2}\right)$ and slopes ranging from 0.001 to 3.67 percent (Jobson, 1996). Results of dye studies for some streams in West Virginia were not included in the data used to develop those equations because the data were incomplete. In order to simplify the development of the equations, Jobson (1996) used only data that represented complete tracer-response curves and that were tabulated. The national equations have been used to develop preliminary zones for source-water protection upstream from some water-supply intakes in West Virginia. This study was done to determine whether the national equations were representative of traveltime and dispersion characteristics of West Virginia streams.

\section{Purpose and Scope}

For this study, traveltime and dispersion data were compiled from all available sources for streams in and near West Virginia and evaluated. Equations developed by Jobson (1996) for the entire United States are compared to traveltime and dispersion measurements made in West Virginia and nearby states to determine whether the equations produce accurate estimates for streams in West Virginia. That determination is based on an evaluation of the prediction errors of the equations when applied to West Virginia streams. Examples of traveltime and dispersion estimates are presented to familiarize readers with the use of the estimation procedures.

\section{Description of Study Area}

West Virginia lies within three physiographic provinces (fig. 1), the Appalachian Plateaus, Valley and Ridge, and Blue Ridge (Fenneman, 1938). The State can be separated into two climatic regions (fig. 1) by a line defined as the Climatic Divide (Wiley and others, 2000). Greater precipitation occurs along and west of the Climatic Divide than to the east, as a consequence of the higher elevations along the Divide and the general movement of weather systems approaching from the west and southwest. Generally, the part of the State west of the Climatic Divide is in the Appalachian Plateaus Physiographic Province, where altitudes range from about 2,500 to 4,861 feet (ft; NAVD 88) at Spruce Knob along the Climatic Divide to about 550 to $650 \mathrm{ft}$ along the Ohio River. The part of West Virginia east of the Climatic Divide is in the Valley and Ridge Physiographic Province, except for the extreme eastern tip of the State, which is in the Blue Ridge Physiographic Province. Altitudes decrease eastward from the Climatic Divide to $274 \mathrm{ft}$ at Harpers Ferry in the Eastern Panhandle (U.S. Geological Survey, 1990, 2006; National Oceanic and Atmospheric Administration, 2006a).

The Appalachian Plateaus Physiographic Province consists of consolidated, mostly siliciclastic sedimentary rocks that have a gentle slope from southeast to northwest near the Climatic Divide and are nearly flat-lying along the Ohio River. One exception is in the northeastern area of the province (west of the Climatic Divide), where the rocks are gently folded, and some carbonate rock crops out (Fenneman, 1938). The rocks in the Appalachian Plateaus Physiographic Province have been eroded to form steep hills and deeply incised valleys. Drainage patterns are dendritic.

The Valley and Ridge Physiographic Province in West Virginia consists of consolidated carbonate and siliciclastic sedimentary rocks that are folded sharply and extensively faulted (Fenneman, 1938). Northeast-trending valleys and ridges parallel the Climatic Divide. Drainage patterns are trellis.

The Blue Ridge Physiographic Province within West Virginia consists predominantly of metamorphosed sandstone and shale (Fenneman, 1938). The province has high relief between mountains and wide valleys that parallel the Climatic Divide. Drainage patterns are trellis.

The climate of West Virginia is primarily continental, with mild summers and cold winters. Major weather systems generally approach from the west and southwest, although polar continental air masses of cold, dry air that approach from the north and northwest are not unusual. Air masses from the Atlantic Ocean sometimes affect the area east of the Climatic Divide and less frequently affect the area west of the Climatic Divide. Generally, tropical continental masses of hot, dry air from the southwest affect the climate west of the Climatic Divide. Tropical maritime masses of warm, moist air from the Gulf of Mexico affect the climate east of the Climatic Divide more than west of the Climatic Divide. Evaporation from local and upwind land surfaces, lakes, and reservoirs also provides a source of moisture that affects the climate of the State (U.S. Geological Survey, 1991; National Oceanic and Atmospheric Administration, 2006a).

Annual precipitation averages about 42 to 45 inches (in.) statewide with about 60 percent received from March through 


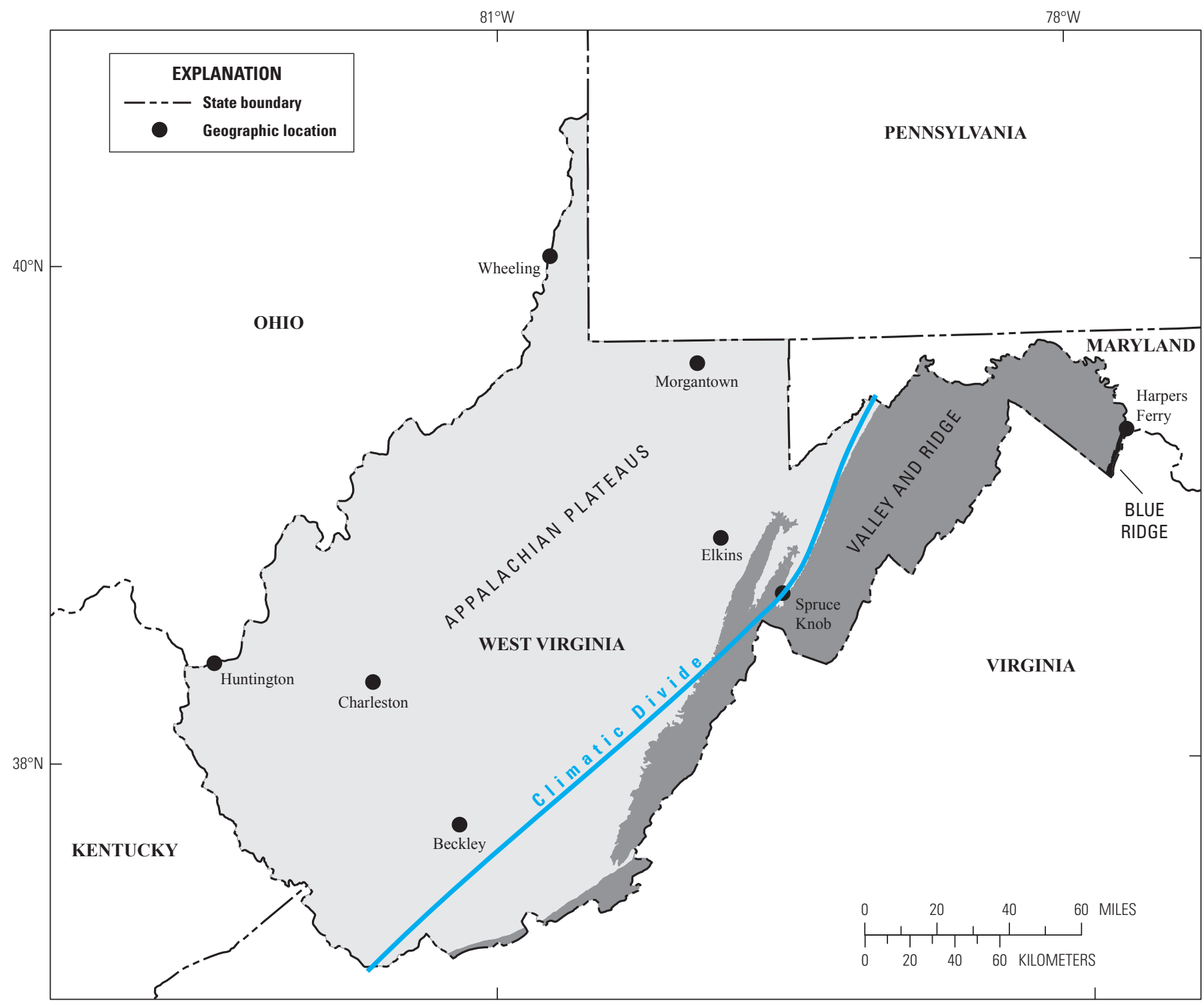

Base from U.S. Geological Survey 1:100,000 digital line graphics.

Physiographic provinces from Fenneman, 1938

Universal Transverse Mercator projection, zone 17, NAD 83.

Figure 1. Appalachian Plateaus, Valley and Ridge, and Blue Ridge Physiographic Provinces, and Climatic Divide in West Virginia.

August. Typically, the most rain is received in July, and the least rain is received during September through November. Annual average precipitation in the State generally decreases northwestward from about 50 to 60 in. along the Climatic Divide to about 40 in. along the Ohio River and increases from about 30 to 35 in. east of the Climatic Divide to about 40 in. in the extreme eastern tip of the State. Greater precipitation along and west of the Climatic Divide is a consequence of the higher elevations along the Divide and the orographic lifting of weather systems generally approaching from the west and southwest. Annual average snowfall follows the general pattern of annual average precipitation, decreasing northwestward from about 36 to 100 in. along the Climatic Divide to about 20 to 30 in. along the Ohio River. East of the Climatic Divide, annual average snowfall ranges from 24 to 36 in. (U.S. Geological Survey, 1991; Natural Resources Conservation Service, 2006; National Oceanic and Atmospheric Administration, 2006a, 2006b). 


\section{Studies of Traveltime and Longitudinal Dispersion in West Virginia Streams}

Traveltime has been studied on a variety of stream reaches in and near West Virginia. These reaches may be broadly divided into free-flowing stream reaches and regulated stream reaches, in which backwater is created by dams or other structures. Traveltime and dispersion characteristics measured in free-flowing stream reaches are likely to be representative of regional conditions, whereas for regulated stream reaches, these characteristics are unique to that reach.

\section{Free-Flowing Stream Reaches}

A free-flowing stream reach lacks artificial structures that would block streamflow and create backwater. Dams are the most common of these structures, but some culverts or low-water bridges also may cause backwater at some flows. Stream reaches containing dams exhibit increased traveltimes relative to the traveltimes of free-flowing streams because of increased storage in the stream channel, particularly at low streamflows. Traveltime through a reach containing a small dam may exhibit the characteristics of a free-flowing stream at high streamflows because the dam is submerged and storage effects become less dominant.

Studies have been conducted on free-flowing stream reaches in the Tug Fork of the Big Sandy River (Bader and others, 1989b); Guyandotte River (Bader and others, 1989a); Little Coal, Big Coal, and Coal Rivers (J.S. Bader, J.L. Chisholm, S.C. Downs, and F.O. Morris, Water Resources of the Coal River Basin, West Virginia: West Virginia Geological and Economic Survey River Bulletin 5, written commun., 1976); New River (Appel and Moles, 1987); Greenbrier River (Clark and others, 1976); North Branch Potomac and Potomac Rivers (Taylor and others, 1984); South Branch Potomac River (Hobba and others, 1972; Jack, 1986); and South Fork Shenandoah and Shenandoah Rivers (Taylor and others, 1986) within and along the borders of West Virginia (fig. 2). Traveltime and dispersion studies of the Monocacy River (Taylor, 1970) and of Antietam and Conococheague Creeks (Taylor and Solley, 1971) in Maryland were considered to be representative of traveltime and dispersion applicable to streams in West Virginia. Information on the reaches and injections, and the traveltime and dispersion data measured in these studies, are summarized in appendix 1, tables 1-1 and 1-2.

A study of the Tuscarawas River (Westfall and Webber, 1977) in southeastern Ohio was considered but determined to be unrepresentative of traveltime and dispersion in West Virginia, primarily because of dams in the study reach. Two studies of the New River that investigated the effects of rapidly changing streamflow on a dye cloud (Appel, 1987; Wiley and Appel, 1989) were excluded from consideration because of uncertainties in assigning a representative streamflow to the reaches.
Plots of traveltimes of the leading edge, peak concentration, and trailing edge of the dye cloud at selected locations on free-flowing stream reaches were constructed from data collected during previous studies to present the traveltime and dispersion characteristics observed in the streams (figs. 3-13, at end of report). Traveltime increases as streamflow and velocity decrease. Longitudinal dispersion characteristics are determined by comparing differences between the leading and trailing edges of the dye cloud at different locations along the stream. Dispersion in a reach increases as streamflow decreases because the residence time increases. The plots show combined results from multiple dye injections along a stream to represent a single dye injection occurring at the most-upstream location. Each streamflow condition (low-, medium-, and (or) high-flow) was plotted separately when more than one condition was studied.

In some of the studies that measured traveltime at different streamflow conditions, dye was injected at different points under different conditions. To allow interpolation between measured traveltimes, all the plots need to be included on the same graph. This required that the curves representing shorter reaches be fit onto curves representing the longest reach for that study. Plots representing reaches that do not begin at the graph origin were positioned by interpolation between measured values when possible. Otherwise, the national equations were used. Traveltime and dispersion plots are not presented for the Monocacy River (Taylor, 1970) or Antietam and Conococheague Creeks (Taylor and Solley, 1971) in Maryland because the streams are not within or along the border of West Virginia and those plots are not needed to estimate traveltimes within West Virginia.

Traveltime and dispersion have not been measured for streams flowing directly into the Ohio River in the northwestern part of West Virginia. Elsewhere in West Virginia, the Bluestone River, Gauley River, Elk River, Little Kanawha River, Middle Island River, Cheat River, Tygart Valley River, and Buckhannon River are large streams containing freeflowing reaches where traveltime and dispersion have not been measured.

\section{Regulated Stream Reaches}

Regulated stream reaches, for the purpose of this report, are reaches with dams and other structures that create backwater and affect traveltime and dispersion. Measurements made on regulated reaches are not transferable to either other regulated reaches or free-flowing reaches, and estimates of traveltime made for free-flowing reaches are not transferable to regulated reaches. Measurements are required to characterize each regulated reach.

Dye studies have been conducted on the regulated streams Kanawha River (Appel, 1991; Wiley, 1993; fig. 14 at end of report) and the upper Ohio River (Wiley, 1997a; figs. 14-16, at end of report). Traveltime predictions are available for the Ohio River from a model maintained by the Ohio 





River Valley Water Sanitation Commission (ORSANCO). These predictions can be made near real time in the event of a significant spill. Traveltimes were determined for the Monongahela River, a regulated stream, using the relations between flow and hydraulic measurements made at a series of cross sections measured in 1948 (Federal Water Pollution Control Administration, 1968; fig. 15, located near the end of this report). Estimates for the Monongahela are likely to be less accurate than dye studies or the ORSANCO model. Traveltimes of the leading edge, peak concentration, and trailing edge of the dye cloud relative to location on the stream are plotted to present the traveltime and dispersion characteristics observed in selected regulated streams.

\section{Estimation of Traveltime and Longitudinal Dispersion in West Virginia Streams Using Plots and National Equations}

Only data from studies conducted on free-flowing stream reaches (absent of any dam structures) were compared to results from the national equations developed by Jobson (1996). Jobson (1996) included stream reaches with dam structures to develop the national equations. Data collected for the September 6, 1983, dye injection 4.9 miles upstream from Morgan Ford on the Shenandoah River, injection number 60, (Taylor and others, 1986) were omitted from analysis because a double peak was observed in the study.

Jobson (1996, equation 4, p. 6) defined the unit concentration as

$$
C_{u}=1 \times 10^{6}\left(\frac{C}{R_{r}}\right)\left(\frac{Q}{M_{i}}\right) \text { or } 1 \times 10^{6}\left(\frac{C}{M_{r}}\right) Q,
$$

where

$$
\begin{gathered}
C_{u} \quad \text { is the unit concentration, in inverse seconds } \\
(1 / \mathrm{s}) ; \\
C \quad \text { is the (measured/observed) concentration, in } \\
\quad \text { pounds per cubic feet }\left(\mathrm{lb} / \mathrm{ft}^{3}\right) \text {; and } \\
R_{r} \quad \text { is the recovery ratio, dimensionless: }
\end{gathered}
$$

$$
R_{r}=\left(\frac{M_{r}}{M_{i}}\right),
$$

where

$$
\begin{array}{cl}
M_{r} & \text { is the mass recovered, in pounds }(\mathrm{lb}) ; \\
M_{i} & \text { is the mass injected, in lb; and } \\
Q & \text { is the streamflow, in cubic feet per second } \\
& \left(\mathrm{ft}^{3} / \mathrm{s}\right) .
\end{array}
$$

The constant $1 \times 10^{6}$ is used in equation 1 to obtain results near unity. Equation 1 was a redefinition from that described by Hubbard and others (1982, p. 35):

$$
C_{U H}=\frac{\left(C_{c o n} \times Q\right)}{M_{i}},
$$

where

$C_{U H} \quad$ is the unit concentration from Hubbard and others (1982), in (micrograms per liter $\times$ cubic feet per second $) /$ pounds $((\mu \mathrm{g} / \mathrm{L})$ $\left.\left(\mathrm{ft}^{3} / \mathrm{s}\right) / \mathrm{lb}\right)$ and

$C_{c o n}$ is the conservative concentration, in $\mu \mathrm{g} / \mathrm{L}$ :

$$
C_{c o n}=\frac{C_{H}}{R_{r}},
$$

where

$$
\begin{array}{cl}
C_{H} & \text { is the (measured/observed) concentration } \\
& \text { from Hubbard and others (1982), in } \mu \mathrm{g} / \mathrm{L} ; \\
R_{r} & \text { is the recovery ratio, dimensionless (see } \\
\quad \text { equation 1); } \\
Q & \text { is the streamflow, in } \mathrm{ft}^{3} / \mathrm{s} ; \text { and } \\
M_{i} & \text { is the mass injected, in } \mathrm{lb} .
\end{array}
$$

All traveltime and dispersion studies included in the West Virginia data set computed unit concentrations using equation 2 with the units $(\mu \mathrm{g} / \mathrm{L})\left(\mathrm{ft}^{3} / \mathrm{s}\right) / \mathrm{lb}$. The unit concentrations in $(\mu \mathrm{g} / \mathrm{L})\left(\mathrm{ft}^{3} / \mathrm{s}\right) / \mathrm{lb}$ were multiplied by $0.06243(1 / \mathrm{s}) /\left[(\mu \mathrm{g} / \mathrm{L})\left(\mathrm{ft}^{3} / \mathrm{s}\right) / \mathrm{lb}\right]$ to obtain unit concentrations as defined by equation $1\left(0.06243\right.$ is determined as $28.317 \mathrm{~L} / \mathrm{ft}^{3}$ $\left.\times 2.205 \times 10^{-9} \mathrm{lb} / \mu \mathrm{g} \times 1 \times 10^{6}\right)$.

Jobson (1996, equation 7, p. 10) determined unit-peak concentrations of dye were related to the elapsed time since injection using the equation

$$
C_{u p}=857 T_{p}^{-0.760\left(Q / Q_{a}\right)^{-0.079}},
$$

where

$$
\begin{gathered}
C_{u p} \quad \begin{array}{l}
\text { is the unit-peak concentration, in } 1 / \mathrm{s} ; \\
T_{p}
\end{array} \text { is the elapsed time from injection to peak } \\
\text { concentration, in hours (h); } \\
Q \quad \begin{array}{c}
\text { is the streamflow at the time of the } \\
\text { measurement, in } \mathrm{ft}^{3} / \mathrm{s} \text {; and }
\end{array} \\
Q_{a} \quad \text { is the mean annual streamflow, in } \mathrm{ft}^{3} / \mathrm{s} .
\end{gathered}
$$

Equation 3 was originally developed using 410 data points with a coefficient of determination $\left(R^{2}\right)$ of 0.91 and a root mean square error (RMSE) of $0.426 \log$ units (127 percent) (Jobson, 1996). Fitting West Virginia data (150 points) to Jobsons's (1996) equation for $C_{u p}$ resulted in a RMSE of $0.139 \log$ units (32.8 percent).

Unit-peak concentration was plotted against the elapsed time from injection to peak concentration with stream reaches separated into those with $Q / Q_{a}$ greater than 0.5 , indicating above-average flows, and values less than 0.5 , indicating below-average flows for the West Virginia data set. Additionally, line plots of equation 3 evaluated for $Q / Q_{a}$ equal to 1.0 for above-average flow and 0.2 for below-average flow were 


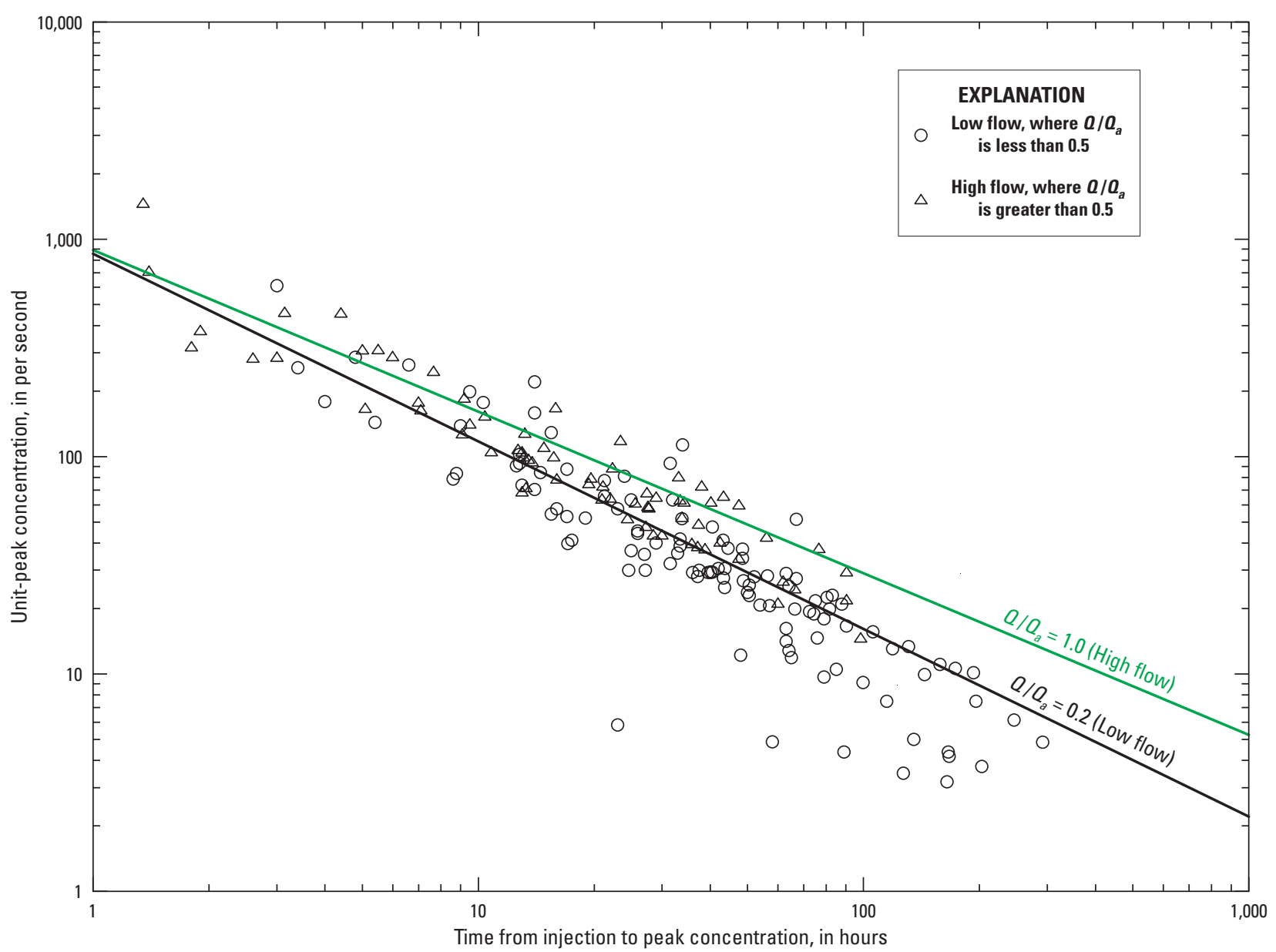

Figure 17. Unit-peak concentrations as a function of traveltime for measurements made in and near West Virginia, 1964-1985, with equation 3 plotted for two values of $Q / Q_{a}$.

added to the plot (fig. 17; Jobson, 1996, fig. 3). The values for $Q / Q_{a}$ for the West Virginia data set averaged 1.11 when $Q / Q_{a}$ was greater than 0.5 (41 data points) and 0.25 when $Q / Q_{a}$ was less than 0.5 (109 data points); values from the national equations (Jobson, 1996) were 1.0 and 0.2 , respectively.

Jobson (1996, equation 12, p. 14) determined that the velocity of the peak concentration $\left(V_{p}\right)$ could be estimated from the following equation modified for use with inch-pound units (the constant 0.094 meters per second $(\mathrm{m} / \mathrm{s})$ was converted to 0.308 feet per second $(\mathrm{ft} / \mathrm{s}))$ :

$$
V_{p}=0.308+\left(0.0143 \times D_{a}^{\prime 0.919} Q_{a}^{\prime-0.469} S^{0.159} \frac{Q}{D_{a}}\right),
$$

where

$$
\begin{aligned}
& V_{p} \quad \text { is the velocity of the peak concentration, in } \\
& \mathrm{ft} / \mathrm{s} ; \\
& D_{a}^{\prime} \quad \text { is the dimensionless drainage area: }
\end{aligned}
$$

$$
D_{a}^{\prime}=\frac{D_{a}^{1.25} g^{0.5}}{Q_{a}},
$$

where

$D_{a} \quad$ is the drainage area (at the end of the reach), in $\mathrm{ft}^{2}$;

$g \quad$ is the acceleration due to gravity, in feet per square second $\left(\mathrm{ft} / \mathrm{s}^{2}\right)\left(32.2 \mathrm{ft} / \mathrm{s}^{2}\right)$;

$Q_{a} \quad$ is the mean annual streamflow (at the end of the reach), in $\mathrm{ft}^{3} / \mathrm{s}$; and

$Q_{a}{ }^{\prime} \quad$ is the dimensionless streamflow:

$$
Q_{a}^{\prime}=\frac{Q}{Q_{a}},
$$

where

$Q \quad$ is the streamflow (at the end of the reach), in $\mathrm{ft}^{3} / \mathrm{s}$, and 
$Q_{a} \quad$ is the mean annual streamflow (at the end of the reach), in $\mathrm{ft}^{3} / \mathrm{s}$;

$S \quad$ is the reach slope, in $\mathrm{ft}$ per $\mathrm{ft}$;

$Q \quad$ is the streamflow (at the end of the reach), in $\mathrm{ft}^{3} / \mathrm{s}$; and

$D_{a} \quad$ is the drainage area (at the end of the reach), in $\mathrm{ft}^{2}$.

Dimensionless variables permit the use of any consistent system of units to obtain equal results. Constants need to be in the same system of units as the variables. Foot-pound units are used in this report because the data were originally reported in foot-pound units. $\left(V_{p}\right.$ in $\mathrm{m} / \mathrm{s}$ is obtained by replacing the constant 0.3084 with 0.094 and using $Q$ in cubic meters per second $\left(\mathrm{m}^{3} / \mathrm{s}\right)$ and $D_{a}$ in cubic meters $\left.\left(\mathrm{m}^{3}\right)\right)$.

Velocity of the peak concentration $\left(V_{p}\right)$ was plotted against the variables on the right side of equation 4 for the West Virginia data set (fig. 18; Jobson, 1996, fig. 9, p. 15). Equation 4 was originally developed using 939 data points with an $R^{2}$ of 0.70 and a RMSE of $0.157 \mathrm{~m} / \mathrm{s}$ or $0.505 \mathrm{ft} / \mathrm{s}$. Equation 4 resulted in a RMSE of $0.630 \mathrm{ft} / \mathrm{s}$ ( 83 percent) using 198 West Virginia data points.

Jobson (1996; equation 13, p. 14; fig. 9, p. 15) determined the maximum probable velocity of the peak concentration $\left(V_{m p}\right)$ using the following equation modified for use with inch-pound units (the constant $0.25 \mathrm{~m} / \mathrm{s}$ was multiplied by $3.28 \mathrm{ft} / \mathrm{m}$ to obtain a constant of $0.82 \mathrm{ft} / \mathrm{s}$ ):

$$
V_{m p}=0.82+\left(0.02 \times{D_{a}^{\prime 0.919}}^{\prime \prime a .469} S^{0.159} \frac{Q}{D_{a}}\right),
$$

where

$$
\begin{aligned}
& \mathrm{V}_{m p} \quad \text { is the maximum probable velocity of the peak } \\
& \text { concentration, in } \mathrm{ft} / \mathrm{s} \text {; } \\
& D_{a}{ }^{\prime} \quad \text { is the dimensionless drainage area (see } \\
& \text { equation 4); } \\
& Q_{a}{ }^{\prime} \quad \text { is the dimensionless streamflow (see } \\
& \text { equation 4); } \\
& S \quad \text { is the reach slope, in } \mathrm{ft} \text { per } \mathrm{ft} \text {; } \\
& Q \quad \text { is the streamflow (at the end of the reach), in } \\
& \mathrm{ft}^{3} / \mathrm{s} \text {; and } \\
& D_{a} \quad \text { is the drainage area (at the end of the reach), }
\end{aligned}
$$

Equation 5 was evaluated by Jobson (1996, Equation 13, p. 14) as an envelope line where 99 percent of the observed values of $V_{p}$ were less than the values of $V_{m p}$. All observed values of $V_{p}$ from the West Virginia data were less than the values predicted for $V_{m p}$ by equation 5, and most of them (195 of 239) were less than the values predicted for $V_{p}$ by equation 4 (fig. 18). Most of the values of $V_{p}$ near $V_{m p}$ are for injection reaches (fig. 18). Dye in injection reaches may travel at higher velocities because of incomplete mixing of the dye with the stream at the beginning of the reach and because many injections were made into the fastest flowing part of the stream.

Jobson (1996; equation 18, fig 12, p. 17) determined the traveltime of the leading edge $\left(\mathrm{T}_{1}\right)$ of a dye cloud in a stream could be predicted by the traveltime of the peak concentration $\left(T_{p}\right)$ using the following equation with an $R^{2}$ of 0.99 and RMSE of $3.78 \mathrm{~h}$ developed from 520 data points:

$$
T_{l}=0.890 T_{p}
$$

where

$$
\begin{aligned}
& T_{l} \quad \begin{array}{l}
\text { is the traveltime of the leading edge since } \\
\text { injection, in } \mathrm{h} \text {, and }
\end{array} \\
& T_{p} \quad \begin{array}{l}
\text { is the traveltime of the peak concentration } \\
\text { since injection, in } \mathrm{h} .
\end{array}
\end{aligned}
$$

When equation 6 was applied to the West Virginia data set (189 data points), the RMSE was $3.38 \mathrm{~h}$ (10 percent).

Jobson (1996, equation 19, p. 18) discussed work by Kilpatrick and Taylor (1986) in which a dye response curve is approximated by a scalene triangle (three unequal sides), and the time of passage of a dye cloud (to the point at which the concentration recedes to 10 percent of the peak concentration) was estimated using the following equation:

$$
T_{d} 10=\frac{2 \times 10^{6}}{C_{u p}},
$$

where

$$
\begin{aligned}
& T_{d} 10 \quad \begin{array}{l}
\text { is duration from the leading edge until the } \\
\text { tracer concentration has reduced to within } \\
10 \text { percent of the peak concentration, in } \mathrm{s}, \\
\text { and }
\end{array} \\
& C_{u p} \quad \begin{array}{c}
\text { is the unit-peak concentration, in } 1 / \mathrm{s}, \\
\text { determined from equation } 3 .
\end{array}
\end{aligned}
$$

$T_{d} 10$ was divided by $3,600 \mathrm{~s} / \mathrm{h}$, then compared to the difference between $T_{l}$ and the traveltime of the trailing edge $\left(T_{t}\right)$ for the West Virginia data set (no comparisons were made by Jobson, 1996). $T_{d} 10$ was estimated using equation 7 , and the RMSE was $3.82 \mathrm{~h}$ (20 percent) using 149 data points. There would have been 150 data points, except a value for $T_{t}$ was not measured on the Hancock to Fort Frederick reach with the dye injection at Paw Paw on May 25, 1984, in the Potomac River, although $T_{t}$ was estimated as $80 \mathrm{~h}$ in order to produce figure 10 for this study.

For equations 3-7, error terms computed using only West Virginia data are similar to, or less than, error terms from the national data set. This indicates that the national equations developed by Jobson (1996) can be used to predict traveltime and dispersion for streams located in West Virginia, but predictions will be less accurate than graphical interpolation between measurements.

\section{Procedures for Estimating Traveltime and Longitudinal Dispersion with Examples}

Reach-specific information, where available, can be used to estimate traveltime and longitudinal dispersion with greater accuracy than can be achieved with the national equations. 


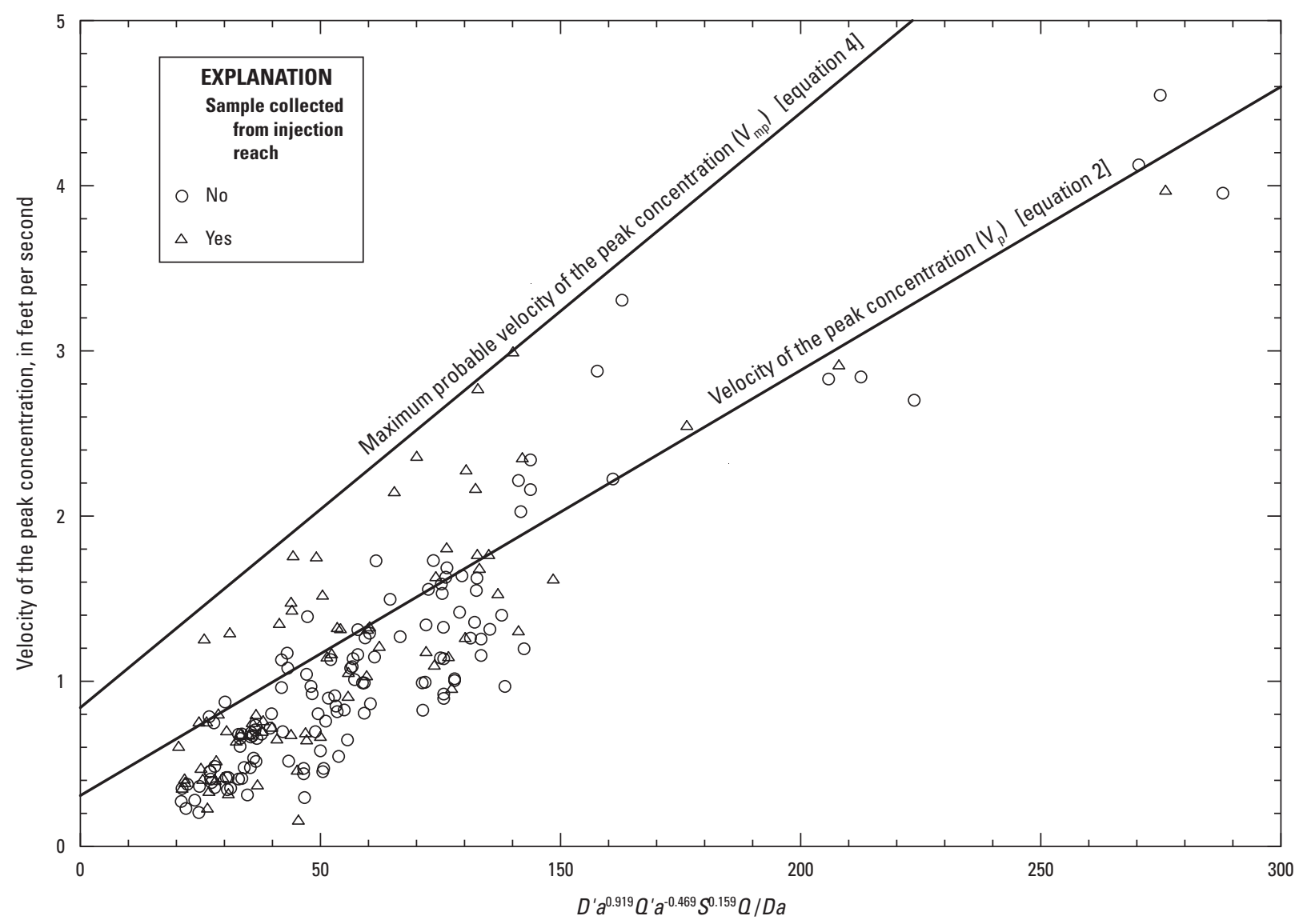

Figure 18. Velocity of the peak concentration as a function of dimensionless drainage area, dimensionless streamflow, dimensionless slope, local streamflow, and drainage area for measurements made in and near West Virginia, 1964-1985.

Estimates of traveltime and dispersion may be made from the plots of traveltime in relation to distance downstream on reaches where studies have been conducted, as long as the streamflows are within the ranges of those studied. Equations may be used to estimate traveltime and dispersion in naturally falling stream reaches where studies have not been conducted or where streamflow is outside the limits of those studied. Maximum probable velocities (estimated from equation 6) and associated traveltime of the leading edge can be determined when not estimating traveltime and dispersion from the plots of traveltime in relation to distance downstream. No estimating procedures are presented for estimating traveltime and dispersion in regulated stream reaches not studied or with flows outside the limits of streamflows studied. Traveltime studies would be needed for each of these reaches to provide reliable estimates.

Estimating traveltime and dispersion requires determining $Q, Q_{a}, D_{a}$, and $S$ for streams in West Virginia. Current $Q$ data are available for many USGS streamflow-gaging stations at $h t t p: / /$ waterdata.usgs.gov/wv/nwis/current/?type $=$ flow. If $Q$ is needed at an ungaged location, estimates may be made by comparing the $D_{a}$ with that of one or more nearby USGS streamflow-gaging stations; in some cases, $Q$ for the ungaged location can be approximated by multiplying the drainage-area ratio $\left(D_{a}\right.$ at the ungaged location divided by $D_{a}$ at a nearby streamflow-gaging station) by $Q$ for the nearby streamflowgaging station (drainage-area ratio method). Flow estimates made using the drainage-area ratio method are likely to be more accurate when they are made for ungaged locations on a gaged stream than when they are made for ungaged locations on an ungaged stream or if the differences in drainage areas are large. $Q_{a}$ has been published for many USGS streamflowgaging stations by Evaldi and others (2009) and in Annual Water Data Reports (http://wdr.water.usgs.gov/). $Q_{a}$ at an ungaged location may be estimated using the drainage-area ratio method described above with one or more nearby USGS streamflow-gaging stations. $D_{a}$ may be determined from a geographic information system (GIS) and has been published for many gaged and ungaged locations in West Virginia by Mathes (1977), Wilson (1979), Mathes and others (1982), Preston and Mathes (1984), Stewart and Mathes (1995), Wiley and others (1995), and Wiley (1997b). Reach slope $(S)$ is determined by dividing the difference in altitude at the beginning and end of a stream reach by the reach length, ensuring altitude and 
reach are in the same units. Altitudes can be determined from USGS topographic maps or from a GIS, such as the interactive map available at $h t t p: / / w w w . m a p w v . g o v /$ (a mouse click in the map viewer will show the altitude at the indicated location). Reach lengths can be measured on USGS topographic maps or from a GIS. The USGS Web application StreamStats (http://streamstats.usgs.gov/) provides access to the information needed to estimate traveltime for the states for which it is available. As of 2013, StreamStats is not available in West Virginia but is available or under development for all the states surrounding West Virginia, so it can be used to obtain information needed to estimate traveltime to the state border for streams that enter West Virginia from an adjacent state.

Below are examples showing the procedures for estimating traveltime and longitudinal dispersion. In all examples, the spill is assumed to be instantaneous and completely mixed. The estimating procedure would be the same if these assumptions were not met, and consequences of this are discussed below in the section "Limitations of Estimating Procedures."

Example 1: A $500 \mathrm{lb}$ spill has occurred on the Tug Fork of the Big Sandy River at Matewan, W.Va. How long does the spill take to reach Kermit, W.Va., and what peak concentration is expected? The streamflow $(Q)$ at the USGS streamflowgaging station 03214500 Tug Fork at Kermit at the time of the spill was available from $h t t p: / / w a t e r d a t a . u s g s . g o v / w v / n w i s /$ $u v ?$ site_no $=03214500$. For this example, we assume a $Q$ of $1,000 \mathrm{ft}^{3} / \mathrm{s}$. A study for this stream reach has been conducted, and the streamflow is within the limits of those studied, $650 \mathrm{ft}^{3} / \mathrm{s}$ to $1,800 \mathrm{ft}^{3} / \mathrm{s}$ (fig. 19).

The traveltime of the leading edge and peak concentration can be estimated from information depicted in figure 19, without the use of the national equation. In this study, no data were reported for the trailing edge, and longitudinal dispersion can be determined only from the leading edge to the peak. Estimates can be made in the following way.

1. From figure 19, interpolate the traveltime of the peak concentration for $1,000 \mathrm{ft}^{3} / \mathrm{s}$ at Kermit:

$$
69 \mathrm{~h}+\left((160 \mathrm{~h}-69 \mathrm{~h})\left(\frac{1,800 \mathrm{ft}^{3} / \mathrm{s}-1,000 \mathrm{ft}^{3} / \mathrm{s}}{1,800 \mathrm{ft}^{3} / \mathrm{s}-650 \mathrm{ft}^{3} / \mathrm{s}}\right)\right)=132 \mathrm{~h} .
$$

2. Interpolate the streamflow for the reach upstream from Matewan:

$1,250 \mathrm{ft}^{3} / \mathrm{s}-\left(\left(1,250 \mathrm{ft}^{3} / \mathrm{s}-350 \mathrm{ft}^{3} / \mathrm{s}\right)\left(\frac{1,800 \mathrm{ft}^{3} / \mathrm{s}-1,000 \mathrm{ft}^{3} / \mathrm{s}}{1,800 \mathrm{ft}^{3} / \mathrm{s}-650 \mathrm{ft}^{3} / \mathrm{s}}\right)\right)=623 \mathrm{ft}^{3} / \mathrm{s}$

3. Interpolate the traveltime of the peak concentration at Matewan:

$47 \mathrm{~h}+\left((121 \mathrm{~h}-47 \mathrm{~h})\left(\frac{1,250 \mathrm{ft}^{3} / \mathrm{s}-623 \mathrm{ft}^{3} / \mathrm{s}}{1,250 \mathrm{ft}^{3} / \mathrm{s}-350 \mathrm{ft}^{3} / \mathrm{s}}\right)\right)=98.5 \mathrm{~h}$.
4. Determine the dispersion between Matewan and Kermit, and correct the traveltimes for a spill occurring at Matewan rather than traveltimes downstream from Welch. The dispersion for the peak concentration and the leading edge between Matewan and Kermit is determined by interpolating the difference in traveltimes between the leading edge and peak concentration for $1,000 \mathrm{ft}^{3} / \mathrm{s}$ from figure 19:

$$
1 \mathrm{~h}+\left((4 \mathrm{~h}-1 \mathrm{~h})\left(\frac{1,800 \mathrm{ft}^{3} / \mathrm{s}-1,000 \mathrm{ft}^{3} / \mathrm{s}}{1,800 \mathrm{ft}^{3} / \mathrm{s}-650 \mathrm{ft}^{3} / \mathrm{s}}\right)\right)=3 \mathrm{~h},
$$

for $1,800 \mathrm{ft}^{3} / \mathrm{s}$ :

$$
1 \mathrm{~h} \times((69 \mathrm{~h}-61 \mathrm{~h})-(47 \mathrm{~h}-40 \mathrm{~h}))=1 \mathrm{~h},
$$

for $650 \mathrm{ft}^{3} / \mathrm{s}$ :

$$
((160 h-143 h)-(121 h-108 h))=4 h .
$$

5. To correct for the spill occurring at Matewan, the traveltime of the peak concentration is calculated as $33.5 \mathrm{~h}$ by subtracting the traveltime from Welch to Matewan $(98.5 \mathrm{~h})$ from the traveltime from Welch to Kermit (132 h), and the traveltime of the leading edge is calculated as 30.5 by subtracting $3 \mathrm{~h}$ for the dispersion of the peak concentration and the leading edge between Matewan and Kermit ( $3 \mathrm{~h}$ was subtracted from $132 \mathrm{~h}$ to plot the leading edge in fig. 19 at $129 \mathrm{~h}$ ).

The unit-peak concentration can be estimated using equation 3:

$$
C_{u p}=857 T_{p}^{-0.760\left(Q / Q_{a}\right)^{-0.079} .}
$$

$Q$ at the time of the spill was $1,000 \mathrm{ft}^{3} / \mathrm{s}$, and $Q_{a}$ is available from Evaldi and others $(2009$, p. 277$)$ as $1,441 \mathrm{ft}^{3} / \mathrm{s}$. Substituting these values into equation 3 gives:

$$
\begin{gathered}
C_{u p}=857(33.5 \mathrm{~h})^{-0.760\left(1,000 \frac{\mathrm{ft}^{3}}{\mathrm{~s}} 11,441 \frac{\mathrm{ft}^{3}}{\mathrm{~s}}\right)^{-0.079}} \text { and } \\
C_{u p}=55.01 / \mathrm{s} .
\end{gathered}
$$

No traveltime of the trailing edge was presented in figure 19, but the traveltime to the trailing edge of the spill can be estimated. The traveltime of the leading edge, $30.7 \mathrm{~h}$, has been interpolated from the plot. The time of passage can be estimated from equation $7\left(2 \times 10^{6} / 55.01 / \mathrm{s}\right.$, and dividing by $3,600 \mathrm{~s} / \mathrm{h}$ to convert $\mathrm{s}$ to $\mathrm{h}$ ), giving $10.1 \mathrm{~h}$. The traveltime of the trailing edge is the sum of the traveltime of the leading edge and the estimated time of passage, giving $30.7 \mathrm{~h}+10.1 \mathrm{~h}$ $=40.8 \mathrm{~h}$.

The peak concentration can be estimated by rearranging equation 1 to solve for $C$, and replacing $C$ with $C_{p}$ and $C_{u}$ with 


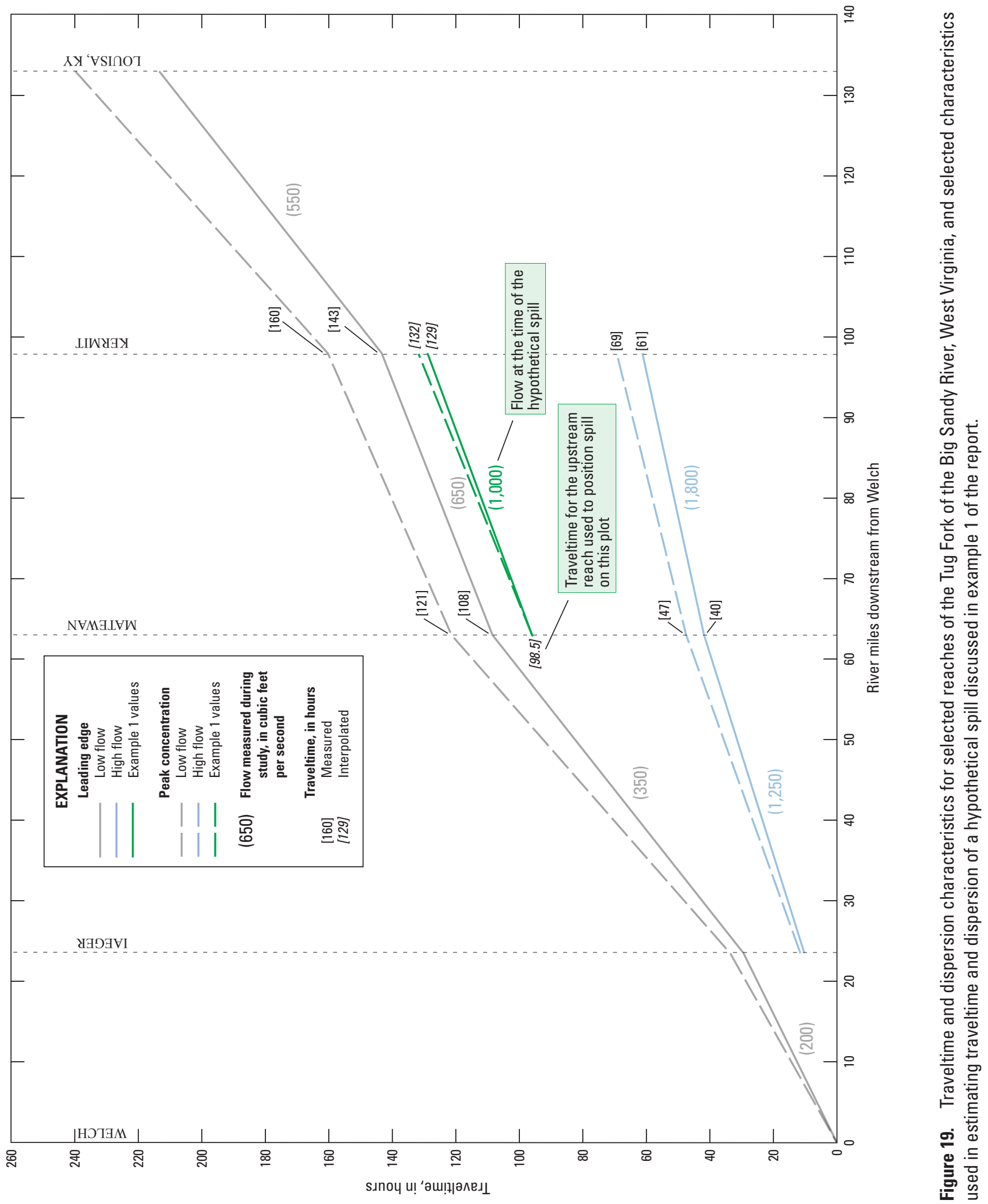


$C_{u p}$ to designate that the particular concentration of interest is the peak concentration:

$$
C_{p}=\left(\frac{C_{u p} \times R_{r} \times M_{i}}{1 \times 10^{6} Q}\right)
$$

$M_{i}$, the spill, was $500 \mathrm{lb}$, and $Q$ was $1,000 \mathrm{ft}^{3} / \mathrm{s} . C_{u p}$ has been estimated as $55.01 / \mathrm{s}$. Assuming that all the spilled material is transported to the end of the reach, $M_{r}$ is equal to $M_{i}$ and $R_{r}$ equals 1 . Substituting these values into equation 8 gives:

$$
\begin{aligned}
C_{p} & =\left(\frac{55.01 / \mathrm{s} \times 1 \times 500 \mathrm{lb}}{1 \times 10^{6} \times 1,000 \mathrm{ft}^{3} / \mathrm{s}}\right) \\
& =2.75 \times 10^{-5} \mathrm{lb} / \mathrm{ft}^{3} .
\end{aligned}
$$

(The peak concentration of $2.75 \times 10^{-5} \mathrm{lb} / \mathrm{ft}^{3}$ can be converted to 440 micrograms per liter $(\mu \mathrm{g} / \mathrm{L})$ by dividing $2.75 \times 10^{-5} \mathrm{lb} / \mathrm{ft}^{3}$ by the product of $28.317 \mathrm{~L} / \mathrm{ft}^{3}$ and $2.205 \times 10^{-9} \mathrm{lb} / \mu \mathrm{g}$.)

Example 2: A spill has occurred on the Greenbrier River at a bridge adjacent to the USGS streamflow-gaging station 03183500 Greenbrier River at Alderson, W.Va. How long does it take the spill to arrive at a bridge adjacent to the USGS streamflow-gaging station 03184000 Greenbrier River at Hilldale, W.Va., and what is the peak concentration that is expected? There are no dye studies for this reach of the Greenbrier River, so estimates will be made using the national equations. The velocity of the peak concentration can be estimated using equation 4 :

$$
V_{p}=0.308+\left(0.0143 \times D_{a}^{\prime 0.919} Q_{a}^{\prime-0.469} S^{0.159} \frac{Q}{D_{a}}\right)
$$

$D_{a}, Q_{a}$, and the river-mile location of the streamflowgaging station 03183500 Greenbrier River at Alderson, W.Va., are $1,619 \mathrm{mi}^{2}, 2,290 \mathrm{ft}^{3} / \mathrm{s}$, and river mile 5.5, respectively (Evaldi and others, 2009). The streamflow at the time of the spill $(Q)$ is available from http://waterdata.usgs.gov/wv/ nwis/uv? site no $=03184000$, and for this example, the $Q$ is $1,500 \mathrm{ft}^{3} / \mathrm{s}$. The river-mile location of the USGS streamflowgaging station 03183500 Greenbrier River at Alderson, W.Va., is $29.2 \mathrm{mi}$ (Evaldi and others, 2009, p. 161). The altitudes of the Greenbrier River at the Hilldale and Alderson streamflow-gaging stations were obtained from the GIS interactive map application at http://www.mapwv.gov/ as 1,394 ft and $1,535 \mathrm{ft}$, respectively.

The dimensionless drainage area is computed as

$$
\begin{aligned}
D_{a}^{\prime} & =\left(\frac{\left(1,619 \mathrm{mi}^{2} \times 5,280^{2} \mathrm{ft}^{2} / \mathrm{mi}^{2}\right)^{1.25} \times\left(32.2 \mathrm{ft} / \mathrm{s}^{2}\right)^{0.5}}{2,290 \mathrm{ft}^{3} / \mathrm{s}}\right) \\
& =5.16 \times 10^{10}
\end{aligned}
$$

The dimensionless streamflow is computed as

$$
\begin{aligned}
Q_{a}^{\prime} & =\frac{1,500 \mathrm{ft}^{3} / \mathrm{s}}{2,290 \mathrm{ft}^{3} / \mathrm{s}} \\
& =0.655 .
\end{aligned}
$$

The dimensionless reach slope is computed as

$$
\begin{aligned}
S & =\frac{(1,535 \mathrm{ft}-1,394 \mathrm{ft})}{(29.2 \mathrm{mi}-5.5 \mathrm{mi}) \times(5,280 \mathrm{ft} / \mathrm{mi})} \\
& =1.13 \times 10^{-3} .
\end{aligned}
$$

Substituting into equation 4 gives

$$
\begin{aligned}
V_{p}= & 0.308 \mathrm{ft} / \mathrm{s}+(0.0143)\left(5.16 \times 10^{10}\right)^{0.919}(0.655)^{-0.469} \\
& \left(1.13 \times 10^{-3}\right)^{0.159}\left(\frac{1,500 \mathrm{ft}^{3} / \mathrm{s}}{1,619 \mathrm{mi} \times(5,280)^{2} \mathrm{ft}^{2} / \mathrm{mi}^{2}}\right) \\
= & 0.308 \mathrm{ft} / \mathrm{s}+(0.0143)\left(6.99 \times 10^{9}\right)(1.22)(0.340)\left(3.32 \times 10^{-8} \mathrm{ft} / \mathrm{s}\right) \\
= & 1.685 \mathrm{ft} / \mathrm{s} .
\end{aligned}
$$

The time for the peak concentration of the spill at Alderson to travel the $23.7 \mathrm{mi}(29.2 \mathrm{mi}-5.5 \mathrm{mi})$ to Hilldale, $T_{p}$, traveling at $1.685 \mathrm{ft} / \mathrm{s}$ is $20.6 \mathrm{~h}((23.7 \mathrm{mi} \times 5,280 \mathrm{ft} / \mathrm{mi})$ $/(1.685 \mathrm{ft} / \mathrm{s} \times 3,600 \mathrm{~s} / \mathrm{h}))$. The leading edge of the spill arrives before the peak concentration in $18.4 \mathrm{~h}(0.890 \times 20.6 \mathrm{~h})$, as determined from equation 6:

$$
T_{l}=0.890 T_{p}
$$

The probable maximum velocity of the peak concentration can be determined from equation 5:

$$
V_{m p}=0.82+\left(0.02 \times D_{a}^{\prime 0.919} Q_{a}^{\prime-0.469} S^{0.159} \frac{Q}{D_{a}}\right) .
$$

Substituting values into equation 5 gives

$$
\begin{aligned}
V_{m p}= & 0.82 \mathrm{ft} / \mathrm{s}+(0.02)\left(5.16 \times 10^{10}\right)^{0.919}(0.655)^{-0.469} \\
& \left(1.127 \times 10^{-3}\right)^{0.159}\left(\frac{1.500 \mathrm{ft}^{3} / \mathrm{s}}{1,619 \mathrm{mi} \times 5,280^{2} \mathrm{ft}^{2} / \mathrm{mi}^{2}}\right) \\
= & 0.82 \mathrm{ft} / \mathrm{s}+(0.02)\left(6.99 \times 10^{9}\right)(1.22)(0.340)\left(3.32 \times 10^{-8} \mathrm{ft} / \mathrm{s}\right) \\
= & 2.75 \mathrm{ft} / \mathrm{s} .
\end{aligned}
$$

The probable minimum time for the peak concentration of the spill at Alderson to travel the $23.7 \mathrm{mi}(29.2 \mathrm{mi}$ $-5.5 \mathrm{mi})$ to Hilldale traveling at $2.75 \mathrm{ft} / \mathrm{s}$ is $12.6 \mathrm{~h}((23.7 \mathrm{mi}$ $\times 5,280 \mathrm{ft} / \mathrm{mi}) /(2.75 \mathrm{ft} / \mathrm{s} \times 3,600 \mathrm{~s} / \mathrm{h}))$. Assuming the peak 
concentration has a velocity of $V_{m p}$, the leading edge of the spill is expected to arrive in $11.2 \mathrm{~h}(0.890 \times 12.6 \mathrm{~h})$, as determined from equation 6 . tion 3:

The unit-peak concentration can be estimated using equa-

$$
C_{u p}=857 T_{p}^{-0.760\left(Q / Q_{a}\right)^{-0.079}}
$$

Substituting values into equation 3 gives

$$
\begin{aligned}
C_{u p} & =857(20.6 \mathrm{~h})^{-0.760\left(\frac{1,500 \mathrm{ft}^{3} / \mathrm{s}}{2,290 \mathrm{ft}^{3} \mathrm{~s}}\right)^{-0.79}} \\
& =79.4 \mathrm{1} / \mathrm{s} .
\end{aligned}
$$

The time of passage of the spill (until the contaminant concentration falls to 10 percent of its peak concentration) at Middlebourne can be estimated from equation 7:

$$
T_{d} 10=\frac{2 \times 10^{6}}{C_{u p}}
$$

Substituting values into equation 7 gives:

$$
\begin{aligned}
T_{d} 10 & =\frac{2 \times 10^{6}}{(79.41 / \mathrm{s})(3,600 \mathrm{~s} / \mathrm{h})} \\
& =6.99 \mathrm{~h} .
\end{aligned}
$$

The peak concentration can be estimated by rearranging equation 1 to solve for $C$ and replacing $C$ with $C_{p}$ and $C_{u}$ with $C_{u p}$ to designate that the particular concentration of interest is the peak concentration:

$$
C_{p}=\left(\frac{C_{u p} \times R_{r} \times M_{i}}{1 \times 10^{6} Q}\right)
$$

$\mathrm{M}_{\mathrm{i}}$, the spill, was $500 \mathrm{lb}$, and $Q$ was $1,500 \mathrm{ft}^{3} / \mathrm{s}$. $C_{u p}$ has been estimated as $79.41 / \mathrm{s}$. Assuming that all the spilled material is transported to the end of the reach, $M_{r}$ is equal to $M_{i}$ and $R_{r}$ equals 1 . Substituting these values into equation 8 gives:

$$
\begin{aligned}
C_{p} & =\left(\frac{79.41 / \mathrm{s} \times 1 \times 500 \mathrm{lb}}{1 \times 10^{6} \times 1,500 \mathrm{ft}^{3} / \mathrm{s}}\right) \\
& =2.65 \times 10^{-5} \mathrm{lb} / \mathrm{ft}^{3} .
\end{aligned}
$$

The peak concentration of $2.65 \times 10^{-5} \mathrm{lb} / \mathrm{ft}^{3} \mathrm{can}$ be converted to $424 \mu \mathrm{g} / \mathrm{L}$ by dividing $2.65 \times 10^{-5} \mathrm{lb} / \mathrm{ft}^{3}$ by the product of $28.317 \mathrm{~L} / \mathrm{ft}^{3}$ and $2.205 \times 10^{-9} \mathrm{lb} / \mu \mathrm{g}$.
Example 3: A $100 \mathrm{lb}$ spill has occurred on Middle Island Creek 8.8 mi upstream from Middleborne, W.Va. (near the town of Tyler and the confluence of McElroy Creek). What is the peak concentration and time to arrival at Middleborne? There are no dye studies for Middle Island Creek, so estimates will be made using the national equations. The velocity of the peak concentration can be estimated using equation 4 :

$$
V_{p}=0.308+\left(0.0143 \times{D_{a}^{\prime 0.919}}_{Q_{a}^{\prime-0.469}} S^{0.159} \frac{Q}{D_{a}}\right) .
$$

There is no USGS streamflow-gaging station at Middlebourne, but there is a station downstream, 03114500 Middle Island Creek at Little, W.Va. The streamflow and drainage area at Little, W.Va., at the time of the spill was $200 \mathrm{ft}^{3} / \mathrm{s}$ and $458 \mathrm{mi}^{2}$, respectively, from http://waterdata.usgs.gov/wv/nwis/ $u v$ ? site no $=03114500 . D_{a}$ at Middlebourne is $359 \mathrm{mi}^{2}$ (Wiley, 1997b, p. 41). $Q$ at Middlebourne is estimated as $157 \mathrm{ft}^{3} / \mathrm{s}$ using drainage-area ratios $((359 / 458) \times 200)$. (Note, if the stream is rising, this $Q$ estimate may be low and result in a low estimate of $V_{p}$ ). The mean annual streamflow at 03114500 Middle Island Creek at Little, W.Va., is reported by Evaldi and others (2009, p. 119) as $648 \mathrm{ft}^{3} / \mathrm{s}$, and $Q_{a}$ at Middlebourne is estimated using drainage-area ratios as $508 \mathrm{ft}^{3} / \mathrm{s}((359 / 458)$ $\times 648$ ). Once $D_{a}, Q$, and $Q_{a}$ have been obtained, the rest of the estimating procedure is the same as in example 2 .

The altitudes of the stream at Middlebourne and $8.8 \mathrm{mi}$ upstream from Middlebourne are determined from the GIS interactive map application available at $h t t p: / / w w w . m a p w v$. $\mathrm{gov} /$ as $665 \mathrm{ft}$ and $687 \mathrm{ft}$, respectively.

The dimensionless drainage area is computed as

$$
\begin{aligned}
D_{a}^{\prime} & =\left(\frac{\left(359 \mathrm{mi}^{2} \times 5,280^{2} \mathrm{ft}^{2} / \mathrm{mi}^{2}\right)^{1.25}\left(32.2 \mathrm{ft} / \mathrm{s}^{2}\right)^{0.5}}{508 \mathrm{ft}^{3} / \mathrm{s}}\right) \\
& =3.54 \times 10^{10} .
\end{aligned}
$$

The dimensionless streamflow is computed as

$$
\begin{aligned}
Q_{a}^{\prime} & =\frac{157 \mathrm{ft}^{3} / \mathrm{s}}{508 \mathrm{ft}^{3} / \mathrm{s}} \\
& =0.309 .
\end{aligned}
$$

The dimensionless reach slope is computed as

$$
\begin{aligned}
S & =\frac{(687 \mathrm{ft}-665 \mathrm{ft})}{(8.8 \mathrm{mi}) \times(5,280 \mathrm{ft} / \mathrm{mi})} \\
& =4.73 \times 10^{-4} .
\end{aligned}
$$


Substituting into equation 4 gives:

$$
\begin{aligned}
V_{p}= & 0.308 \mathrm{ft} / \mathrm{s}+(0.0143)\left(3.54 \times 10^{10}\right)^{0.919}(0.309)^{-0.469} \\
& \left(4.73 \times 10^{-4}\right)^{0.159}\left(\frac{157 \mathrm{ft}^{3} / \mathrm{s}}{359 \mathrm{mi}^{2} \times 5,280^{2} \mathrm{ft}^{2} / \mathrm{mi}^{2}}\right) \\
= & 0.308 \mathrm{ft} / \mathrm{s}+(0.0143)\left(4.94 \times 10^{9}\right)(1.74)(0.296)\left(1.57 \times 10^{-8} \mathrm{ft} / \mathrm{s}\right) \\
= & 0.877 \mathrm{ft} / \mathrm{s} .
\end{aligned}
$$

The time for the peak concentration $\left(T_{p}\right)$ of the spill to travel the $8.8 \mathrm{mi}$ to Middlebourne, traveling at $0.877 \mathrm{ft} / \mathrm{s}$, is $14.7 \mathrm{~h}((8.8 \mathrm{mi} \times 5,280 \mathrm{ft} / \mathrm{mi}) /(0.877 \mathrm{ft} / \mathrm{s} \times 3,600 \mathrm{~s} / \mathrm{h}))$. The leading time of arrival of the leading edge of the spill is determined from equation 6 :

$$
T_{l}=0.890 T_{p},
$$

and substituting into equation 6 gives and arrival time for the leading edge of $13.1 \mathrm{~h}=0.890(14.7 \mathrm{~h})$.

The probable maximum velocity of the peak concentration can be determined from equation 5 :

$$
V_{m p}=0.82+\left(0.02 \times D_{a}^{\prime 0.919} Q_{a}^{\prime-0.469} S^{0.159} \frac{Q}{D_{a}}\right) .
$$

Substituting values into equation 5 gives

$$
\begin{aligned}
V_{m p}= & 0.82 \mathrm{ft} / \mathrm{s}+(0.02)\left(3.54 \times 10^{10}\right)^{0.919}(0.309)^{-0.469} \\
& \left(4.73 \times 10^{-4}\right)^{0.159}\left(\frac{157 \mathrm{ft}^{3} / \mathrm{s}}{359 \mathrm{mi}^{2} \times 5,280^{2} \mathrm{ft}^{2} / \mathrm{mi}^{2}}\right) \\
= & 0.82 \mathrm{ft} / \mathrm{s}+(0.02)\left(4.94 \times 10^{9}\right)(1.74)(0.296)\left(1.57 \times 10^{-8} \mathrm{ft} / \mathrm{s}\right) \\
= & 1.62 \mathrm{ft} / \mathrm{s} .
\end{aligned}
$$

The time for the peak concentration of the spill to travel the $8.8 \mathrm{mi}$ to Middlebourne traveling at the probable maximum velocity of $1.62 \mathrm{ft} / \mathrm{s}$ is $7.99 \mathrm{~h}((8.8 \mathrm{mi} \times 5,280 \mathrm{ft} / \mathrm{mi})$ $/(1.62 \mathrm{ft} / \mathrm{s} \times 3,600 \mathrm{~s} / \mathrm{h}))$. On the basis of the probable maximum velocity of the peak concentration, the leading edge of the spill would be expected to arrive in $7.11 \mathrm{~h}(0.890$ $\times 7.99 \mathrm{~h}$ ), as determined using equation 6 . tion 3:

The unit-peak concentration can be estimated using equa-

$$
C_{u p}=857 T_{p}^{-0.760\left(Q / Q_{a}\right)^{-0.079}}
$$

Substituting values into equation 3 gives

$$
\begin{aligned}
C_{u p} & =857(14.7 \mathrm{~h})^{-0.760\left(\frac{157 \mathrm{ft}^{3} / \mathrm{s}}{508 \mathrm{ft}^{3} / \mathrm{s}}\right)^{-0.079}} \\
& =91.01 / \mathrm{s} .
\end{aligned}
$$

The time of passage of the spill (until the contaminant concentration falls to 10 percent of its peak concentration) at Middlebourne can be estimated as $6.10 \mathrm{~h}$ from equation 7 :

$$
T_{d} 10=\frac{2 \times 10^{6}}{C_{u p}} .
$$

Substituting values into equation 7 gives:

$$
\begin{aligned}
T_{d} 10 & =\frac{2 \times 10^{6}}{(91.01 / \mathrm{s})(3,600 \mathrm{~s} / \mathrm{h})} \\
& =6.10 \mathrm{~h} .
\end{aligned}
$$

The peak concentration can be estimated by rearranging equation 1 to solve for $C$ and replacing $C$ with $C_{p}$ and $C_{u}$ with $C_{u p}$ to designate that the particular concentration of interest is the peak concentration:

$$
C_{p}=\left(\frac{C_{u p} \times R_{r} \times M_{i}}{1 \times 10^{6} Q}\right) .
$$

$M_{i}$, the spill, was $100 \mathrm{lb}$, and $Q$ was estimated as $157 \mathrm{ft}^{3} / \mathrm{s}$. $C_{u p}$ has been estimated as $91.01 / \mathrm{s}$. Assuming that all the spilled material is transported to the end of the reach, $M_{r}$ is equal to $M_{i}$ and $R_{r}$ equals 1 . Substituting these values into equation 8 gives:

$$
\begin{aligned}
C_{p} & =\left(\frac{91.01 / \mathrm{s} \times 1 \times 100 \mathrm{lb}}{1 \times 10^{6} \times 157 \mathrm{ft}^{3} / \mathrm{s}}\right) \\
& =5.80 \times 10^{-5} \mathrm{lb} / \mathrm{ft}^{3} .
\end{aligned}
$$

The peak concentration of $5.80 \times 10^{-5} \mathrm{lb} / \mathrm{ft}^{3}$ can be converted to $929 \mu \mathrm{g} / \mathrm{L}$ by dividing $5.80 \times 10^{-5} \mathrm{lb} / \mathrm{ft}^{3}$ by the product of $28.317 \mathrm{~L} / \mathrm{ft}^{3}$ and $2.205 \times 10^{-9} \mathrm{lb} / \mu \mathrm{g}$.

\section{Limitations of Estimating Procedures}

Regulated stream reaches include those navigable waters controlled by lock and dam structures in West Virginia. Stream reaches with uncontrolled dams or structures that create backwater can have similar hydraulic properties to those that are actively managed. This report does not distinguish which of the stream reaches contain structures that prevent the national equations from being applicable.

Traveltime and dispersion typically were measured when streamflows were relatively steady. Typically, streamflows were slightly receding rather than rising. Dye was injected in the center of streamflow or in multiple locations at the center points of halves or thirds of the total cross-sectional streamflow. The streamflow, injection, and solute characteristics used in the study may not be those that occur in an actual spill. 
Traveltime and dispersion characteristics of a stream reach are functions of streamflow and vary greatly throughout the range of flows. If flows are higher or lower in a reach than they were when traveltime and dispersion were determined, traveltime and dispersion values may differ greatly from the values at the time of the study. The national equations may provide the most accurate estimates of these characteristics. In Pennsylvania streams with velocity measurements made at flows higher than those used to develop the national equations, Reed and Stuckey (2002) found that the national equations produced velocity estimates greater than those that had been measured. This indicates that management actions, such as shutting down water intakes, are likely to protect the water supply from intake of the spills if management actions occur within the times predicted using the national equations.

Rapidly changing streamflow can affect traveltime, and estimates are likely to be in error when streamflow is changing. Both increases and decreases in streamflow occur as a wave that travels faster than the spill. Two experimental dye studies were conducted on the New River by Appel (1987) and Wiley and Appel (1989) in which streamflow was increased and decreased by changing releases from Bluestone Dam. The wave passed through the dye cloud as the dye cloud moved downstream. Increases in streamflow decreased the peak concentration $\left(C_{p}\right)$ and traveltime of the peak concentration $\left(T_{p}\right)$. Decreases in streamflow increased the peak concentration $\left(C_{p}\right)$ and traveltime of the peak concentration $\left(T_{p}\right)$. The decreased traveltime associated with rising streamflow is likely to be of great concern to water managers responding to a spill.

Estimates will be affected when a spill is inadequately mixed across the channel. A dye injection near the edge of a streambank (or from a much smaller tributary stream) will take four times as much stream length for adequate mixing across the channel as a dye injection in the center of the stream (Kilpatrick and Wilson, 1989, p. 13). Also, most of the values of $V_{p}$ that were close in magnitude to the $V_{m p}$ line in figure 18 are injection reaches. Traveltimes will likely be less than those determined by the estimating equations and procedures if the spill is in the center of the stream, and traveltimes will likely be greater than those determined by the estimating equations and procedures if the spill is near the streambank. Material that was carried away from a floodplain by rising flood waters would be transported much the same way, as if it had been spilled on or near the streambank.

Contaminant characteristics might differ from dye by being more or less conservative or less soluble. Rhodamine dye is not conservative, and it may be adsorbed to sediment or taken up by vegetation. Salts, including those already dissolved in brine, are likely to be conservative. Many organic materials and fertilizers are less conservative and less soluble than dye. Some volatile organic compounds are insoluble and, when spilled, remain on the surface of streams instead of dispersing throughout the water column.

Field work for the oldest reach-specific studies discussed in this report was done as early as 1964 (Taylor and others, 1984). Traveltimes that were determined more than 40 years ago likely represent present conditions well in stream channels that remain substantially the same. Traveltime between two points on a stream could be affected by changes in reach length or slope, as in the case of a reconfigured stream channel. Changes to the bed profile could also change traveltime. Decreases in bed complexity caused by dredging or channelization could decrease traveltime. Increases in bed complexity, such as fish habitat enhancement or a natural stream channel design project, could increase traveltime. Construction or removal of a dam or dam-like structure could also change traveltime of a stream reach. The authors are not aware of studies that have measured changes in traveltime and dispersion in relation to stream-channel modifications and would not rely on assumptions about increased traveltime during response to a spill. Channel and bed features are likely to affect traveltime through a reach so that it is not constant, and the plots that show traveltime increasing in a linear manner through the reach are intended as approximations.

\section{Summary}

The U.S. Geological Survey, in cooperation with West Virginia Bureau for Public Health, Office of Environmental Health Services, compiled and evaluated traveltime and dispersion information representative of West Virginia, validated national equations, and presented examples for estimating traveltime and dispersion for streams in West Virginia. Traveltime and dispersion data were not available for streams flowing directly into the Ohio River in the northwestern part of the State. The Bluestone River, Gauley River, Elk River, Little Kanawha River, Middle Island Creek, Cheat River, Tygart Valley River, and Buckhannon River are large streams in West Virginia without any traveltime and dispersion information available.

Traveltime in a free-flowing stream reach increases as streamflow decreases. Dispersion in a free-flowing stream reach increases as streamflow decreases because the residence time in the reach increases as streamflow and velocity decrease. Dispersion in a regulated stream reach generally is less than dispersion in a free-flowing reach. National equations (Jobson, 1996) were found to predict traveltime and dispersion for streams located in West Virginia with error characteristics comparable to those reported for the national data set. The root mean square error (RMSE) of the national equation for predicting unit-peak concentration was reported by Jobson (1996) to be $0.426 \log$ units (127 percent). The national equations were used to predict the unit-peak concentrations for reaches in the West Virginia data set with an RMSE of 0.139 log units (32.8 percent). The RMSE of the national equation for the velocity of the peak concentration was reported to be 0.157 meters per second $(\mathrm{m} / \mathrm{s})$ or 0.505 feet per second $(\mathrm{ft} / \mathrm{s})$; the RMSE was 0.630 $\mathrm{ft} / \mathrm{s}$ (83 percent) when the equation was applied to reaches in the West Virginia data set. Ninety-nine percent of the observations in the national data set have velocities less than or equal to the maximum probable velocities estimated for the peak concentration. All observed velocities of the peak concentration in 
the West Virginia data set are less than the maximum probable velocities estimated from the national equations. The national equation resulted in a traveltime for the leading edge of a dye cloud for reaches in West Virginia with an RMSE of $3.38 \mathrm{~h}$ (10 percent); the RMSE for all data was $3.78 \mathrm{~h}$. Time of passage of a dye cloud was estimated using the national equation without a statistical measure, but an RMSE of $3.82 \mathrm{~h}$ (20 percent) was determined for reaches in West Virginia.

Where reach-specific information is available, it may be used to make traveltime estimates that are more accurate than those made using the national equations. Traveltime and dispersion estimates can be made from the reach-specific plots of traveltime as a function of streamflow and location on streams where plots are available. In the absence of reach-specific plots, or where streamflow is outside the limits of historic studies, traveltime and dispersion estimates for free-flowing stream reaches can be made from equations. No estimating procedures are presented for traveltime and dispersion for regulated stream reaches not studied or for studied reaches when streamflows are outside the range of streamflows studied.

Rapidly changing streamflows can affect traveltime and dispersion. In two experimental studies in the New River, increases in streamflow decreased the peak concentration and its traveltime. Decreases in streamflow increased the peak concentration and its traveltime.

Inadequate mixing across the stream channel can affect traveltime and dispersion. Traveltimes will likely be greater than those determined using the estimating equations and procedures if the spill is in the center of the stream, and traveltimes will likely be less than those determined using the estimating equations and procedures if the spill is near the streambank.

\section{Acknowledgments}

The authors thank U.S. Geological Survey colleagues Greg Koltun and Marla Stuckey for their technical reviews of this report.

\section{References Cited}

Appel, D.H., 1987, Solute traveltime and dispersion in the New River, West Virginia, in New River Symposium, 1987, Proceedings: National Park Service, p. 59-70.

Appel, D.H., 1991, Traveltime and dispersion data for the Kanawha River, West Virginia, 1989: U.S. Geological Survey Open-File Report 91-57, 16 p.

Appel, D.H., and Moles, S.B., 1987, Traveltime and dispersion in the New River, Hinton to Gauley Bridge, West Virginia: U.S. Geological Survey Water-Resources Investigations Report 87-4012, 21 p.
Bader, J.S., Chisholm, J.L., Bragg, R.L., and Downs, S.C., 1989a, Water resources of the Guyandotte River Basin, West Virginia: West Virginia Geologic and Economic Survey River Basin Bulletin 7, 130 p.

Bader, J.S., Mathes, M.V., and Runner, G.S., 1989b, Water resources of the Tug Fork of the Big Sandy River Basin West Virginia, Kentucky, and Virginia and Twelvepole Creek Basin, West Virginia: West Virginia Geologic and Economic Survey River Basin Bulletin 8, 113 p.

Clark, W.E., Chisholm, J.L., and Frye, P.M., 1976, Water resources of the upper New River Basin, West Virginia: West Virginia Geologic and Economic Survey River Basin Bulletin 4, 87 p.

Evaldi, R.D., Ward, S.M., and White, J.S., 2009, Summary of West Virginia water-resources data through September 2008: U.S. Geological Survey Open-File Report 2009$1199,326 \mathrm{p}$.

Federal Water Pollution Control Administration, 1968, Time of travel of water under low flow conditions in the Monongahela, upper Ohio, and Allegheny Rivers Pennsylvania and West Virginia: Wheeling Field Station, Ohio River Basin Project, Work Document No. 19, 22 p.

Fenneman, N.M., 1938, Physiography of eastern United States: New York, McGraw-Hill, 714 p.

Hobba, W.A., Jr., Friel, E.A., and Chisholm, J.L., 1972, Water resources of the Potomac River Basin, West Virginia: West Virginia Geologic and Economic Survey River Basin Bulletin 3, $110 \mathrm{p}$.

Hubbard, E.F., Kilpatrick, F.A., Martens, L.A., and Wilson, Jr., J.F., 1982, Measurement of time of travel and dispersion in streams by dye tracing: U.S. Geological Survey Techniques of Water-Resources Investigations, book 3 , chap. A9, 44 p.

Jack, A.R., 1986, Traveltime and dispersion of a soluble dye in the South Branch Potomac River, Petersburg to Green Springs, West Virginia: U.S. Geological Survey WaterResources Investigations Report 84-4167, 14 p.

Jobson, H.E., 1996, Prediction of traveltime and longitudinal dispersion in rivers and streams: U.S. Geological Survey Water-Resources Investigations Report 96-4013, 69 p.

Jobson, H.E., 2000, Estimating the variation of travel time in rivers by use of wave speed and hydraulic characteristics: U.S. Geological Survey Water-Resources Investigations Report 00-4187, $40 \mathrm{p}$.

Kilpatrick, F.A., and Taylor, K.R., 1986, Application of dispersion data: Water Resources Bulletin of the American Water Resources Association, v. 22, no. 4, p. 537-548. 
Kilpatrick, F.A., and Wilson, J.F., Jr. 1989, Measurement of time of travel in streams by dye tracing: U.S. Geological Survey Techniques of Water-Resources Investigations, book 3, chap. A9, 27 p.

Mathes, M.V, Jr., 1977, Drainage areas of the Guyandotte River Basin, West Virginia: U.S. Geological Survey Open-File Report 77-801, 56 p.

Mathes, M.V., Kirby, J.R., Payne, D.D., and Shultz, R.A., 1982, Drainage areas of the Kanawha River Basin, West Virginia: U.S. Geological Survey Open-File Report 82-351, 222 p.

National Oceanic and Atmospheric Administration, 2006a, Climate of West Virginia, accessed September 30, 2006, at http://cdo.ncdc.noaa.gov/climatenormals/clim60/states/ Clim_WV_01.pdf.

National Oceanic and Atmospheric Administration, 2006b, Total precipitation in inches by month for climate divisions, accessed September 30, 2006, at http://www.cdc.noaa.gov/ USclimate/pcp.state.19712000.climo.html.

Natural Resources Conservation Service, 2006, West Virginia precipitation data/maps, accessed September 30, 2006, at http://www.ncgc.nrcs.usda.gov/products/datasets/climate/ data/precipitation-state/wv.html.

Preston, J.S., and Mathes, M.V., 1984, Stream drainage areas for the Little Kanawha River Basin, West Virginia: U.S. Geological Survey Open-File Report 84-861, 171 p.

Reed, L.A., and Stuckey, M.H., 2002, Prediction of velocities for a range of streamflow conditions in Pennsylvania: U.S. Geological Survey Water-Resources Investigations Report 01-4214, $13 \mathrm{p}$.

Stewart, D.K., and Mathes, M.V., 1995, Drainage areas of the Monongahela River Basin, West Virginia: U.S. Geological Survey Open-File Report 95-170, 79 p.

Taylor, K.R., 1970, Traveltime and concentration attenuation of a soluble dye in the Monocacy River, Maryland: Maryland Geological Survey Information Circular 9, 23 p.

Taylor, K.R., James, R.W., Jr., and Helinsky, B.M., 1984, Traveltime and dispersion in the Potomac River, Cumberland, Maryland to Washington, D.C.: U.S. Geological Survey Open-File Report 83-861, 55 p.

Taylor, K.R., James, R.W., Jr., and Helinsky, B.M., 1986, Traveltime and dispersion in the Shenandoah River and its tributaries, Waynesboro, Virginia, to Harpers Ferry, West Virginia: U.S. Geological Survey Water-Resources Investigations Report 86-4065, 60 p.

Taylor, K.R., and Solley, W.B., 1971, Traveltime and concentration attenuation of a soluble dye in Antietam and Conococheague Creeks, Maryland: Maryland Geological Survey Information Circular 12, 25 p.
U.S. Geological Survey, 2013, 1:24,000 Digital Line Graphics: accessed June 21, 2013, at https://lta.cr.usgs.gov/DLGs.

U.S. Geological Survey, 2013, National Hydrography Dataset: accessed June 21, 2013, at http://nhd.usgs.gov.

U.S. Geological Survey, 1990, National water summary 1987-Hydrologic events and water supply and use: U.S. Geological Survey Water-Supply Paper 2350, 553 p.

U.S. Geological Survey, 1991, National water summary 1988-89-Hydrologic events and floods and droughts: U.S. Geological Survey Water-Supply Paper 2375, 591 p.

U.S. Geological Survey, 2013, The National Map, accessed June 21, 2013, at http://nationalmap.gov .

Westfall, A.O., and Webber, E.E., 1977, Time of travel of solute in the Tuscarawas River Basin, Ohio, August and September, 1974: U.S. Geological Survey Water-Resources Investigations Report 77-23, 7 p.

Wiley, J.B., 1993, Traveltime and dispersion data, including associated discharge and water-surface elevation data, Kanawha River, West Virginia, 1991: U.S. Geological Survey Open-File Report 93-121, 31 p.

Wiley, J.B., 1997a, Traveltime and dispersion data, including associated discharge and water-surface elevation data, for the Upper Ohio River, Pennsylvania, Ohio, and West Virginia; October through November 1991: U.S. Geological Survey Open-File Report 97-562, 42 p.

Wiley, J.B., 1997b, Drainage areas of West Virginia streams tributary to the Ohio River: U.S. Geological Survey OpenFile Report 97-231, 70 p.

Wiley, J.B., and Appel, D.H., 1989, Hydraulic characteristics of the New River in the New River Gorge National River, West Virginia: U.S. Geological Survey Open-File Report 89-243, $34 \mathrm{p}$.

Wiley, J.B., Atkins, J.T., and Tasker, G.D., 2000, Estimating magnitude and frequency of peak discharges for rural, unregulated streams in West Virginia: U.S. Geological Survey Water-Resources Investigations Report 00-4080, 93 p.

Wiley, J.B., Hunt, M.L., and Stewart, D.K., 1995, Drainage areas of the Potomac River Basin, West Virginia: U.S. Geological Survey Open-File Report 95-292, 60 p.

Wilson, J.F., Jr., Cobb, E.D., and Kilpatrick, F.A., 1986, Fluorometric procedures for dye tracing: U.S. Geological Survey Techniques of Water Resources Investigations, book 3, chap. A12, 34 p.

Wilson, M.W., 1979, Drainage areas of the Twelvepole Creek Basin, West Virginia; Big Sandy River Basin, West Virginia; Tug Fork Basin, Virginia, Kentucky, West Virginia: U.S. Geological Survey Open-File Report 79-746, 49 p. 


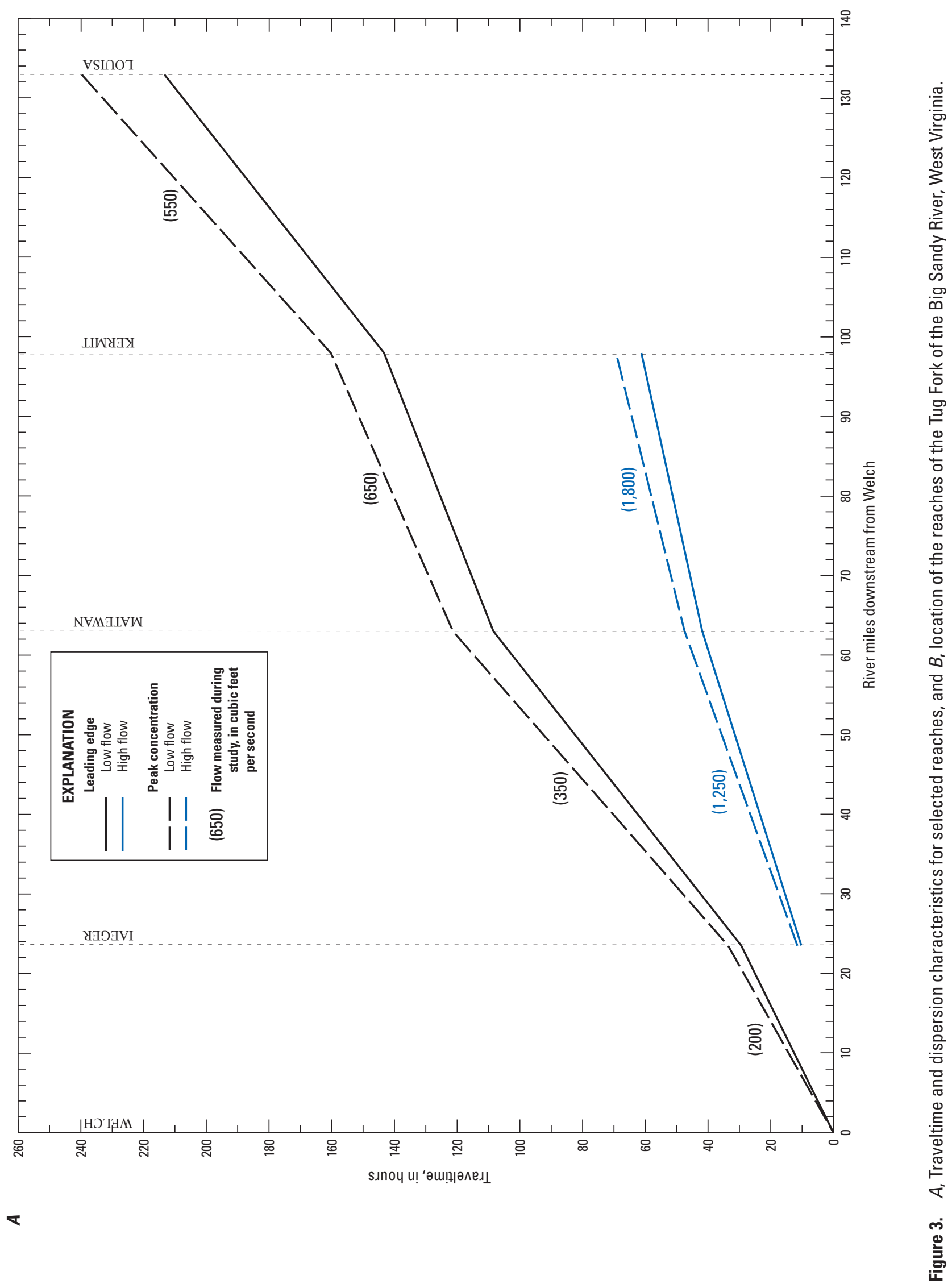




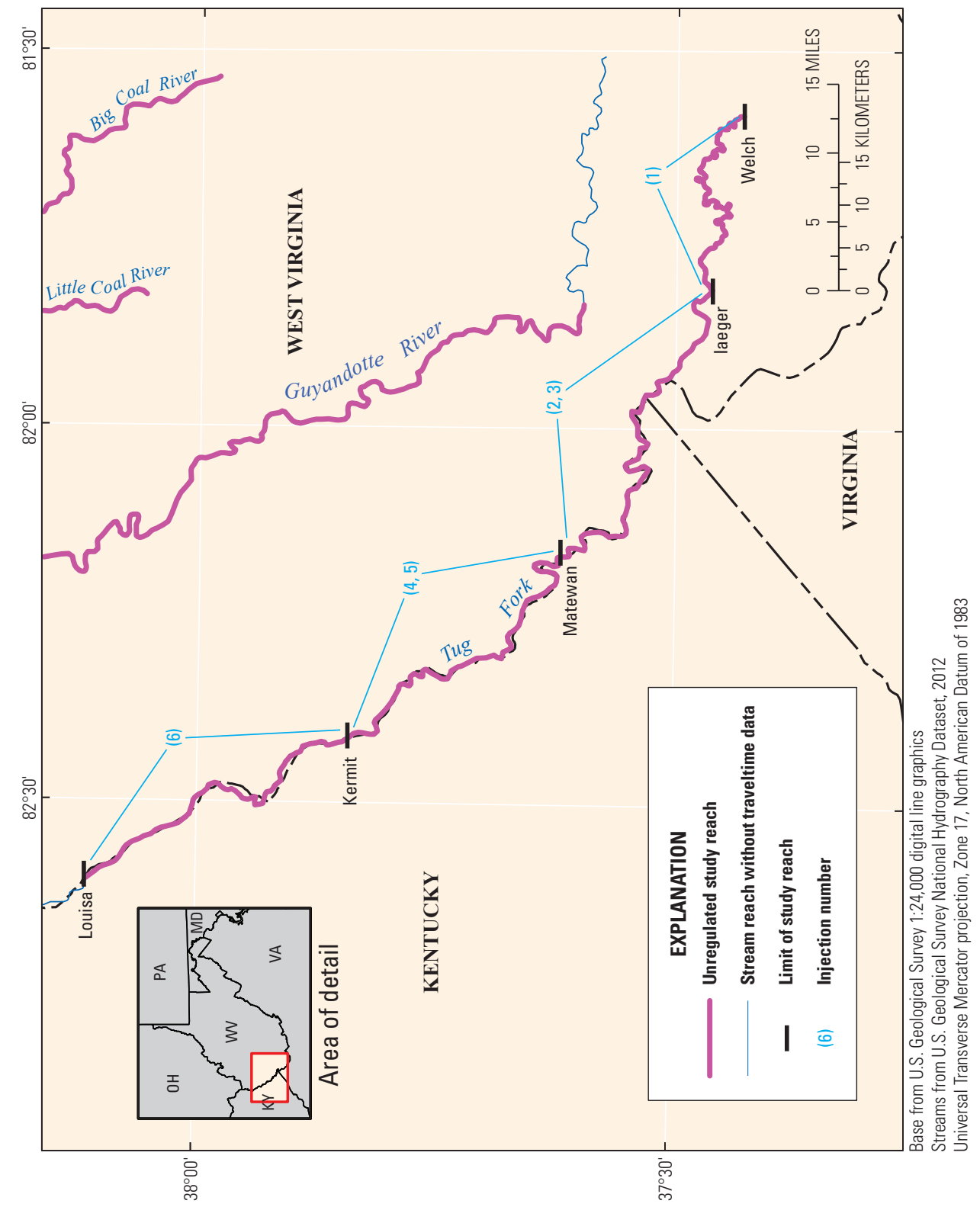









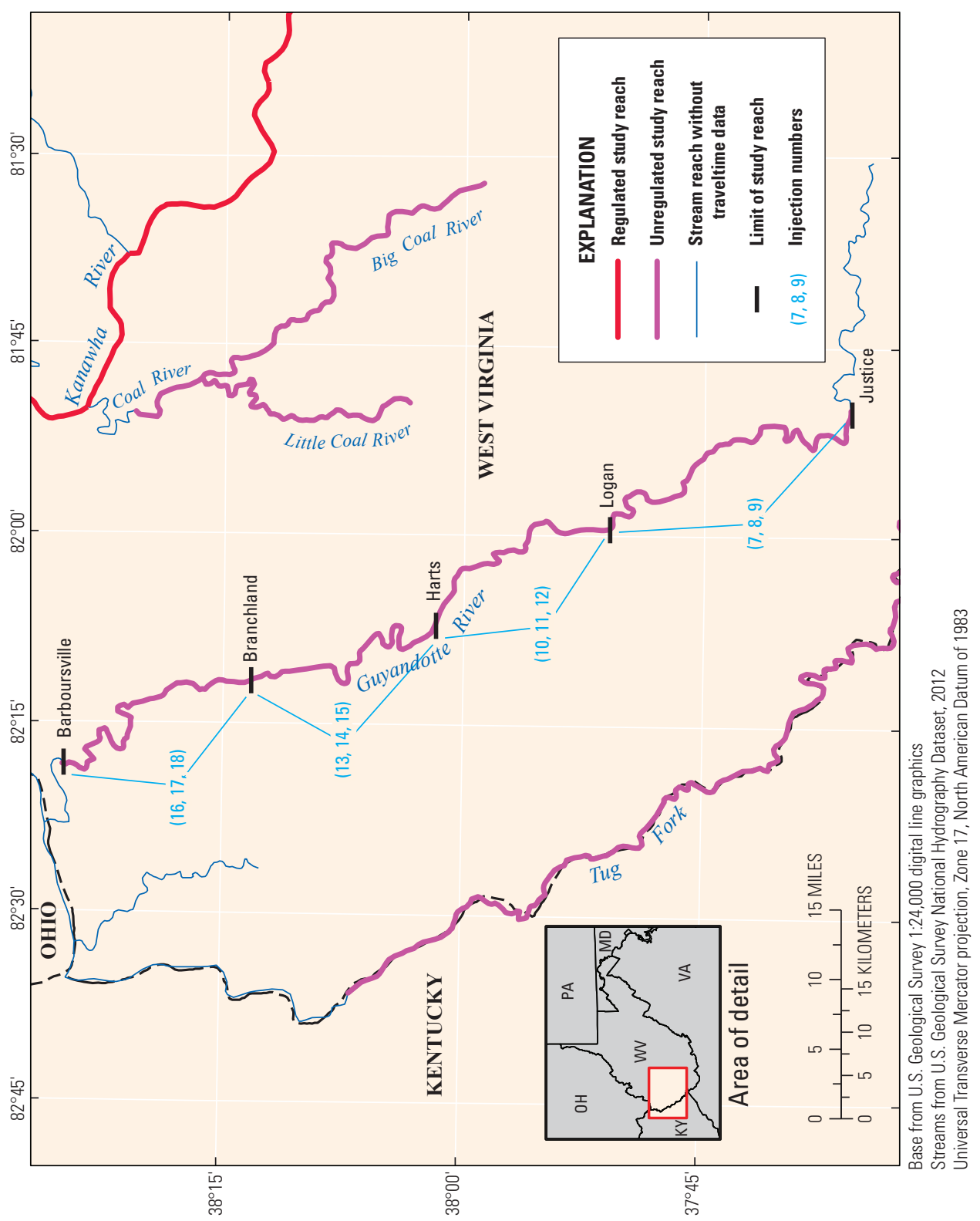




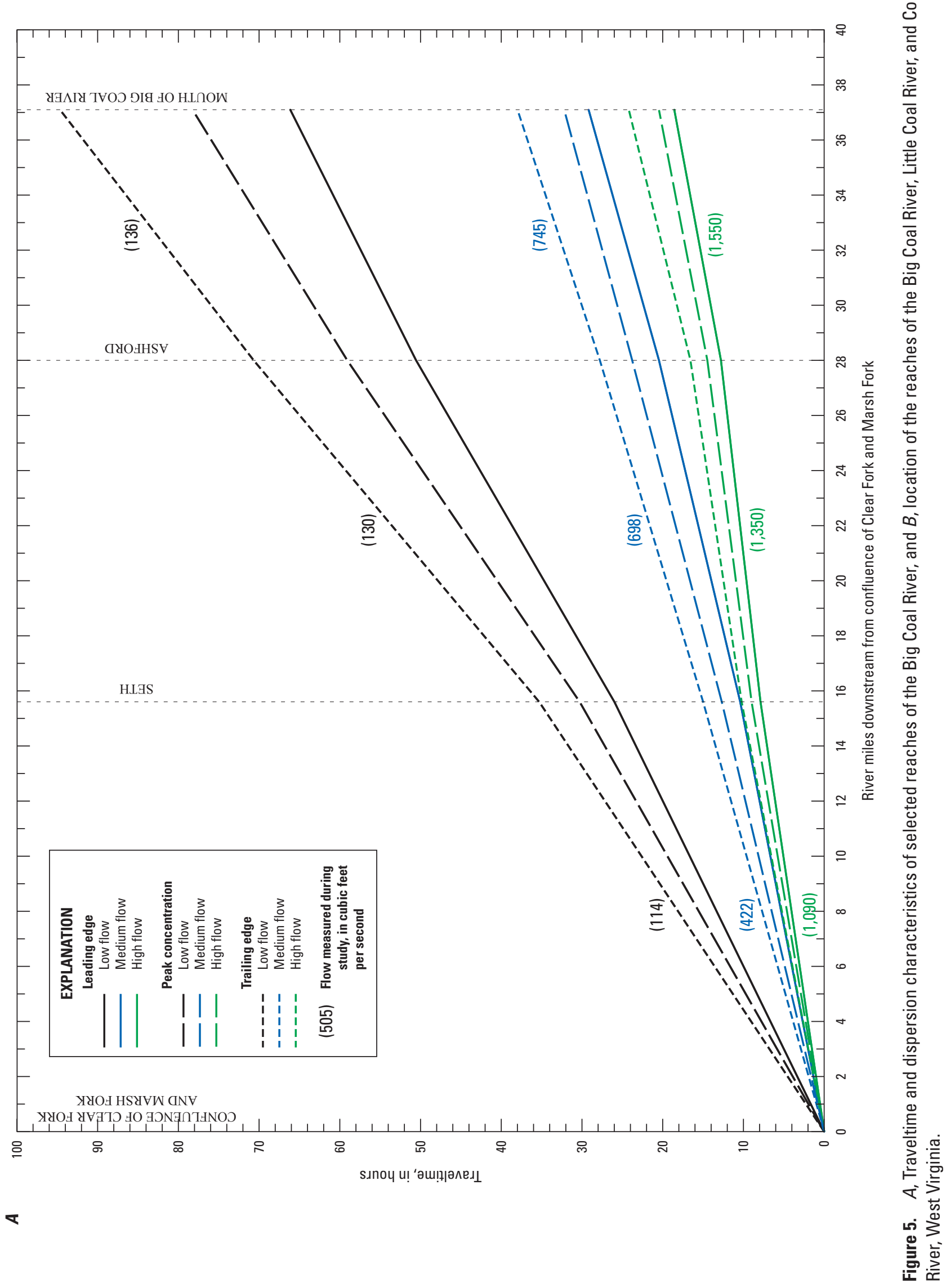




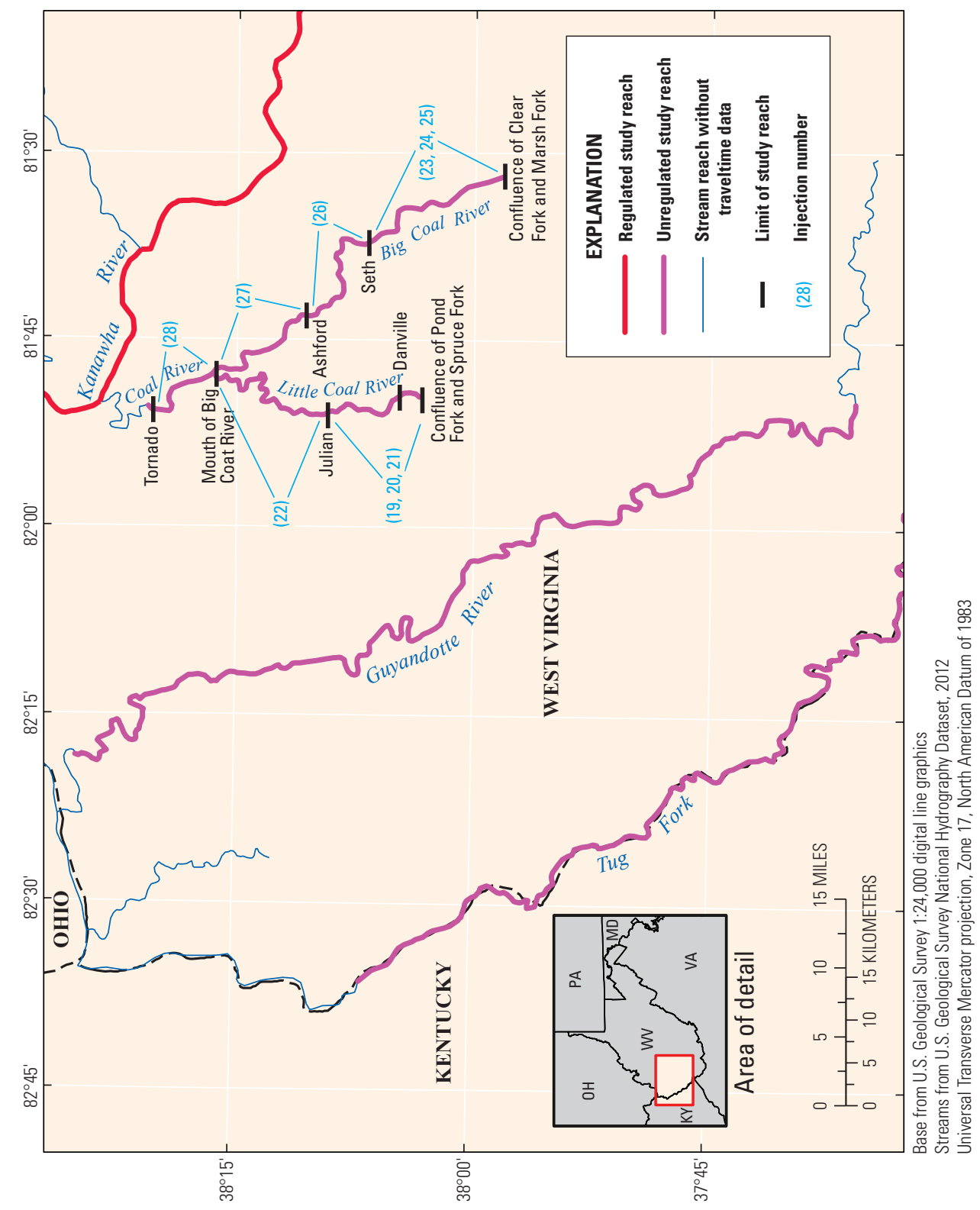

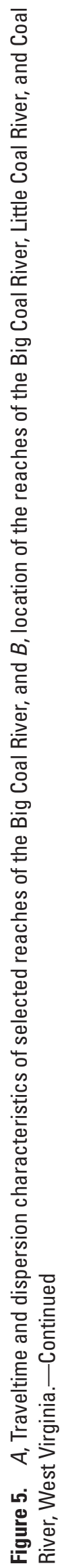




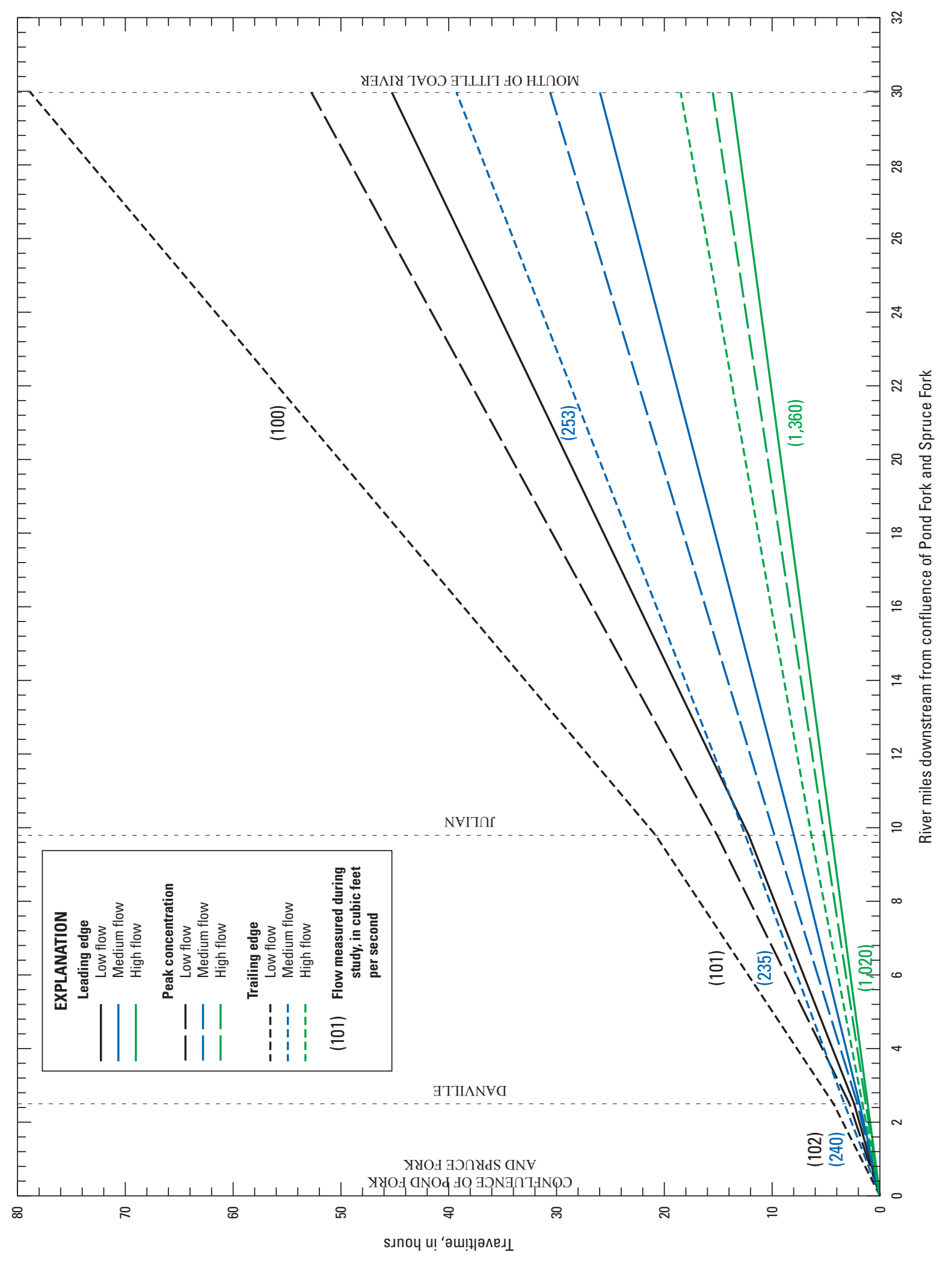

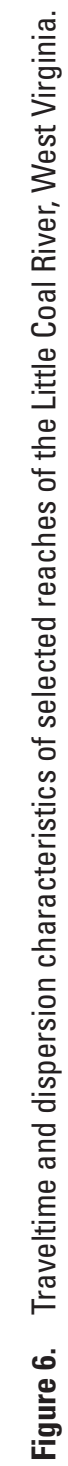









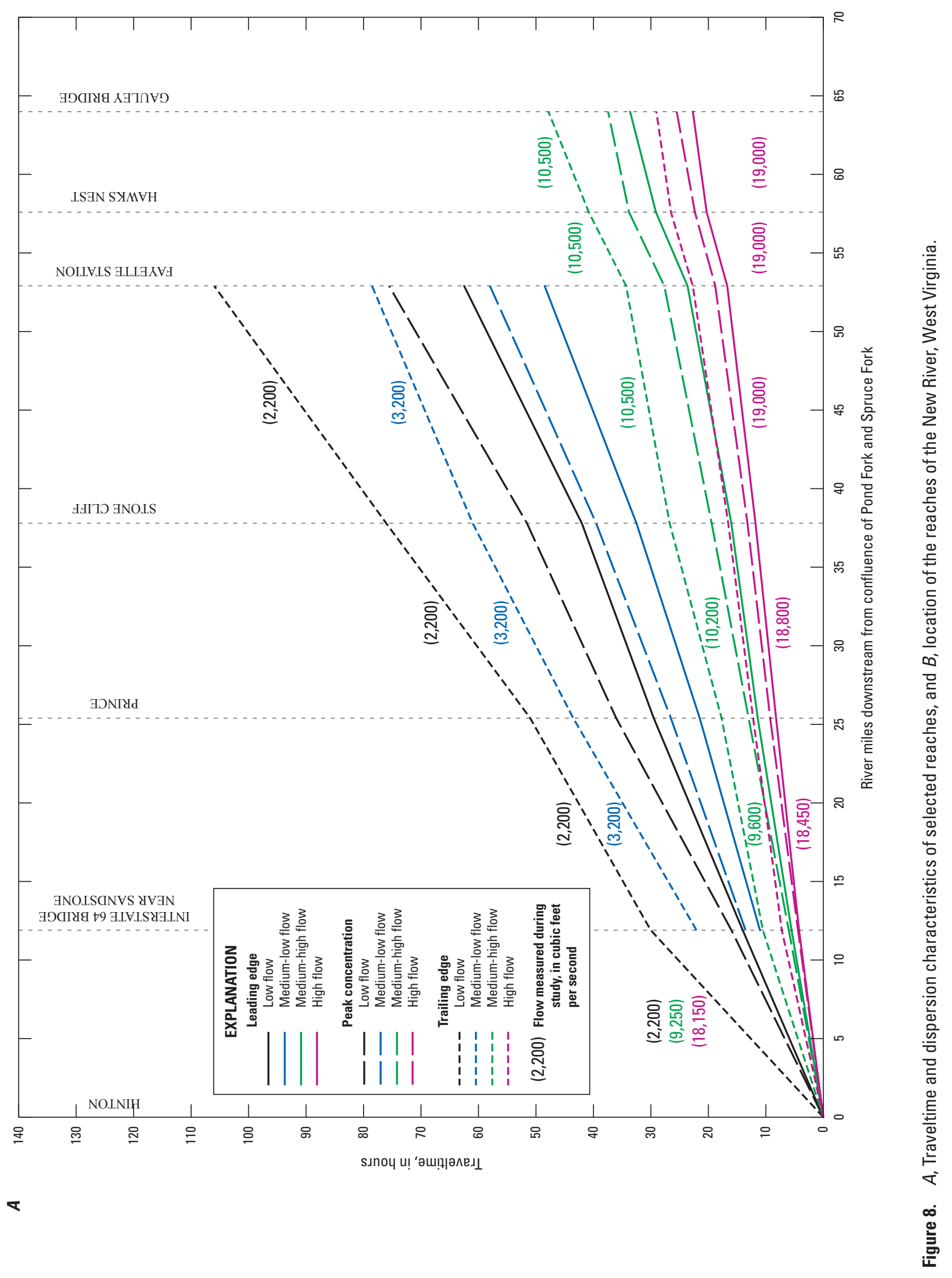




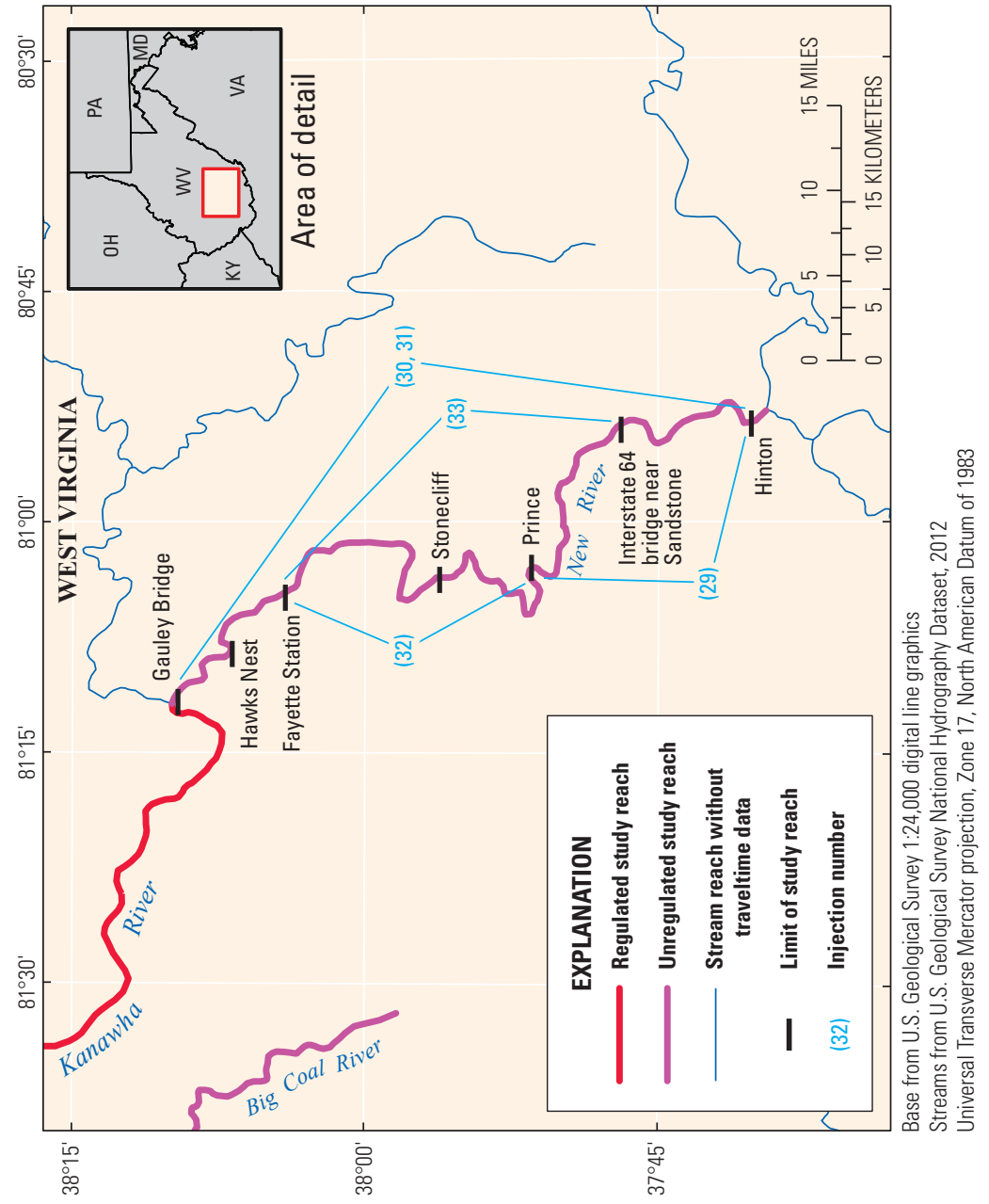




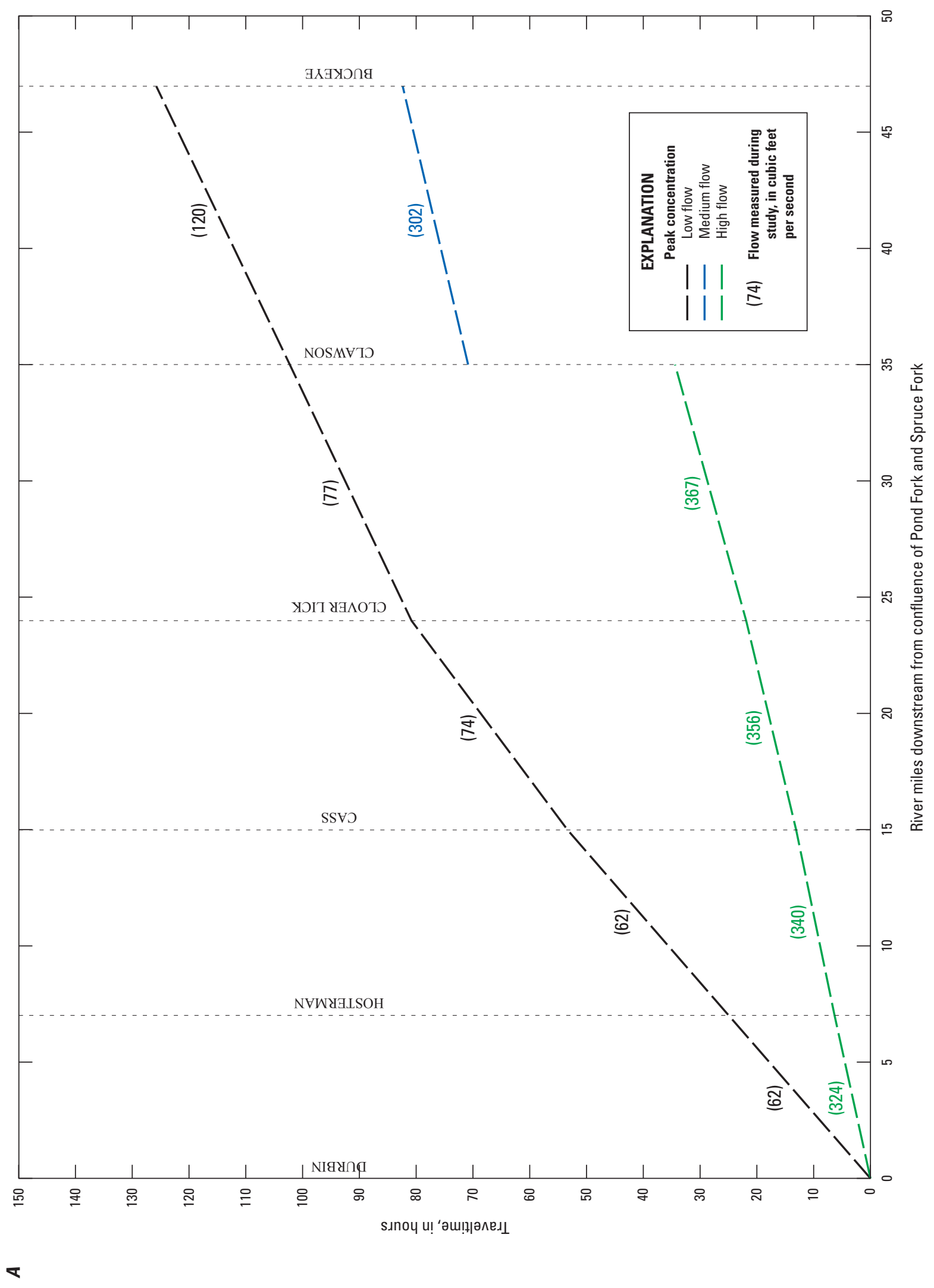




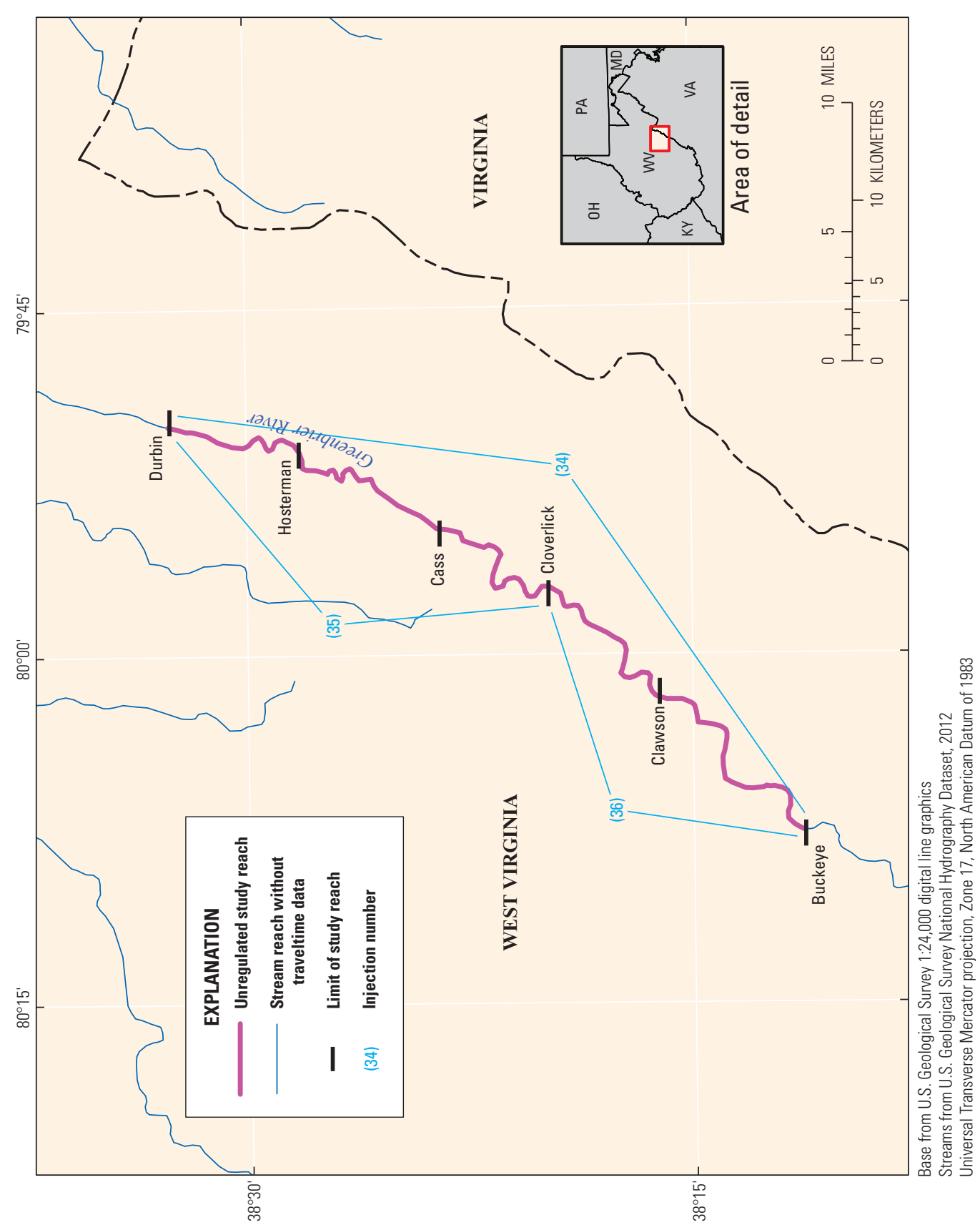




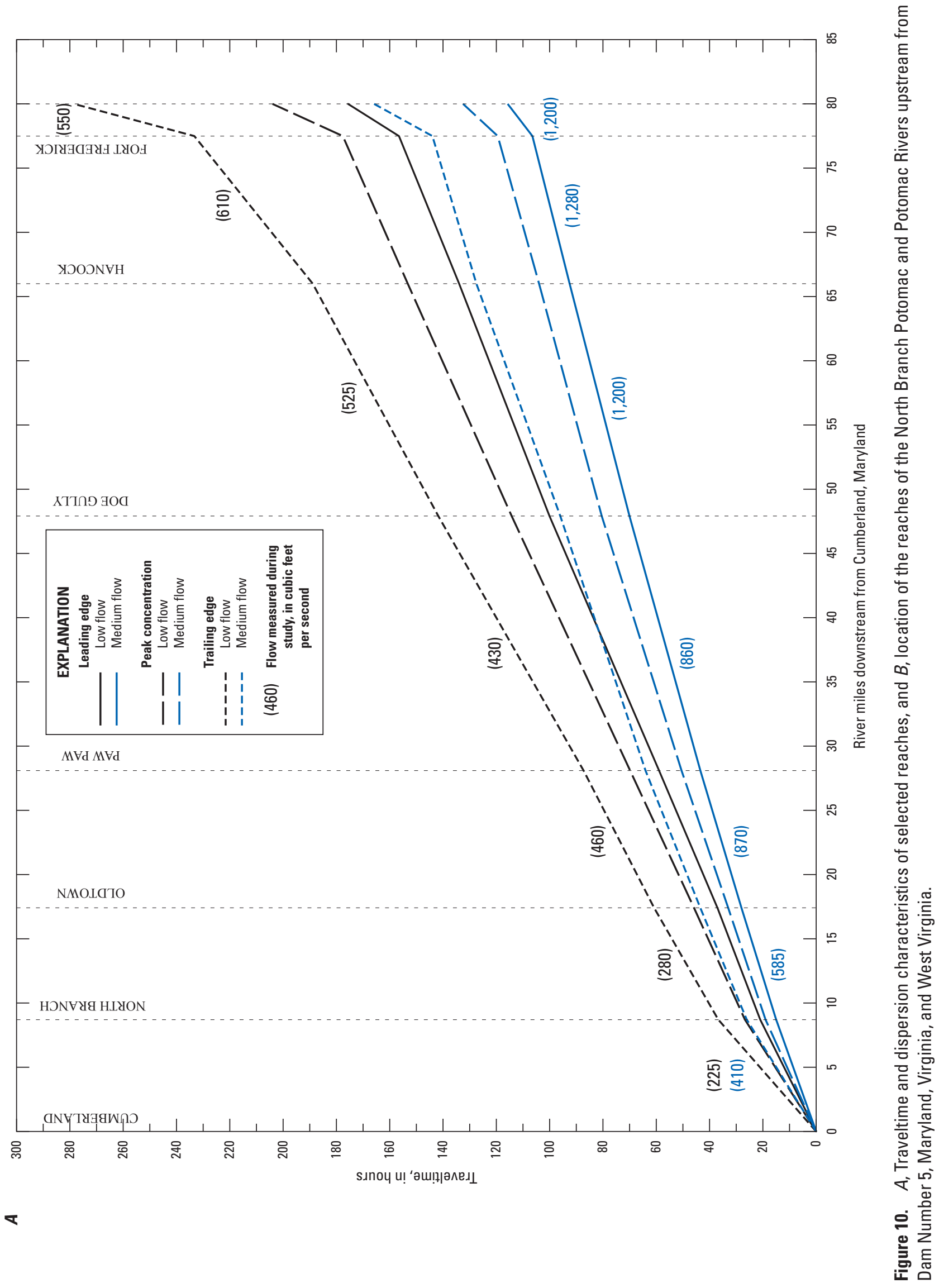



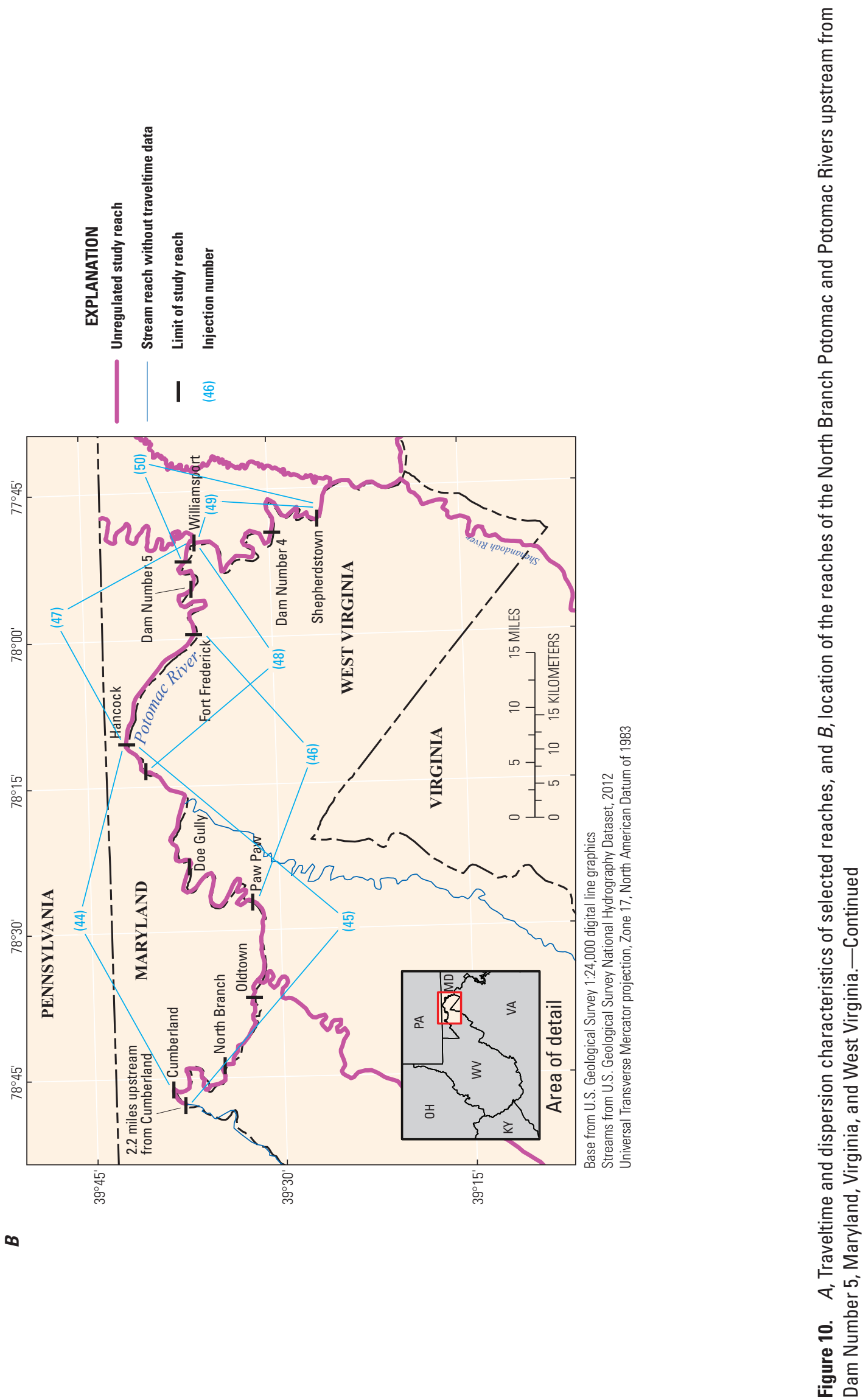


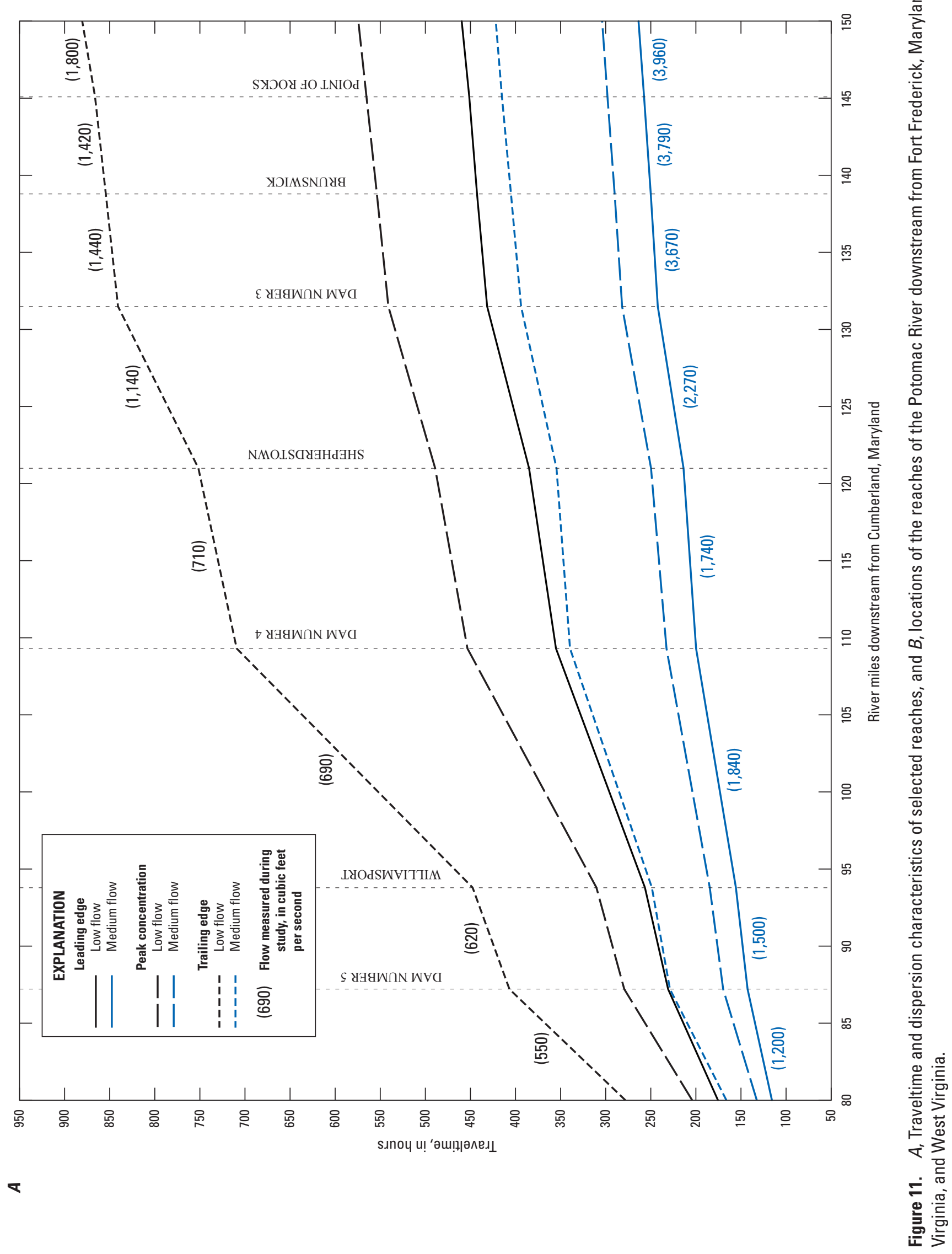



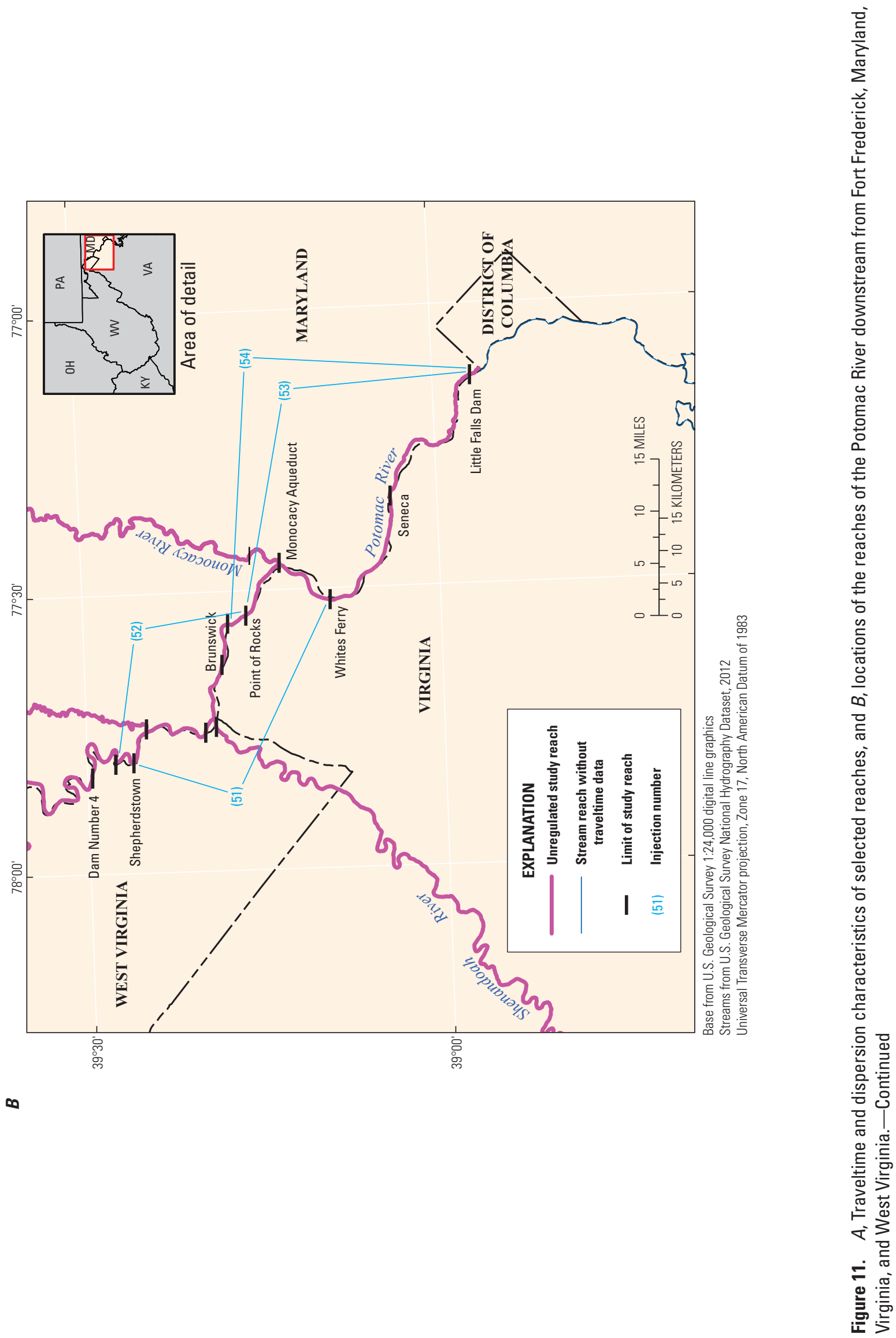


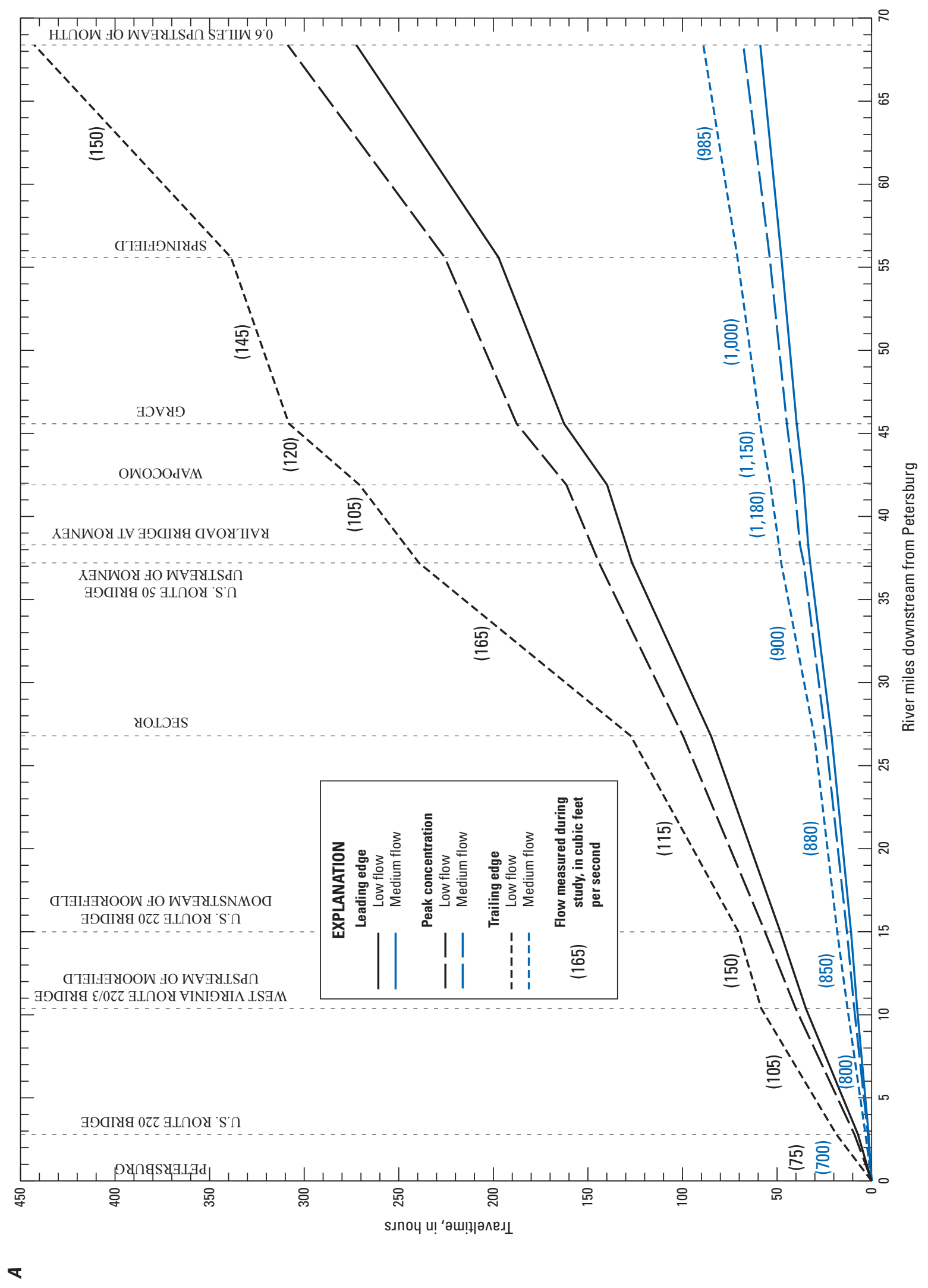



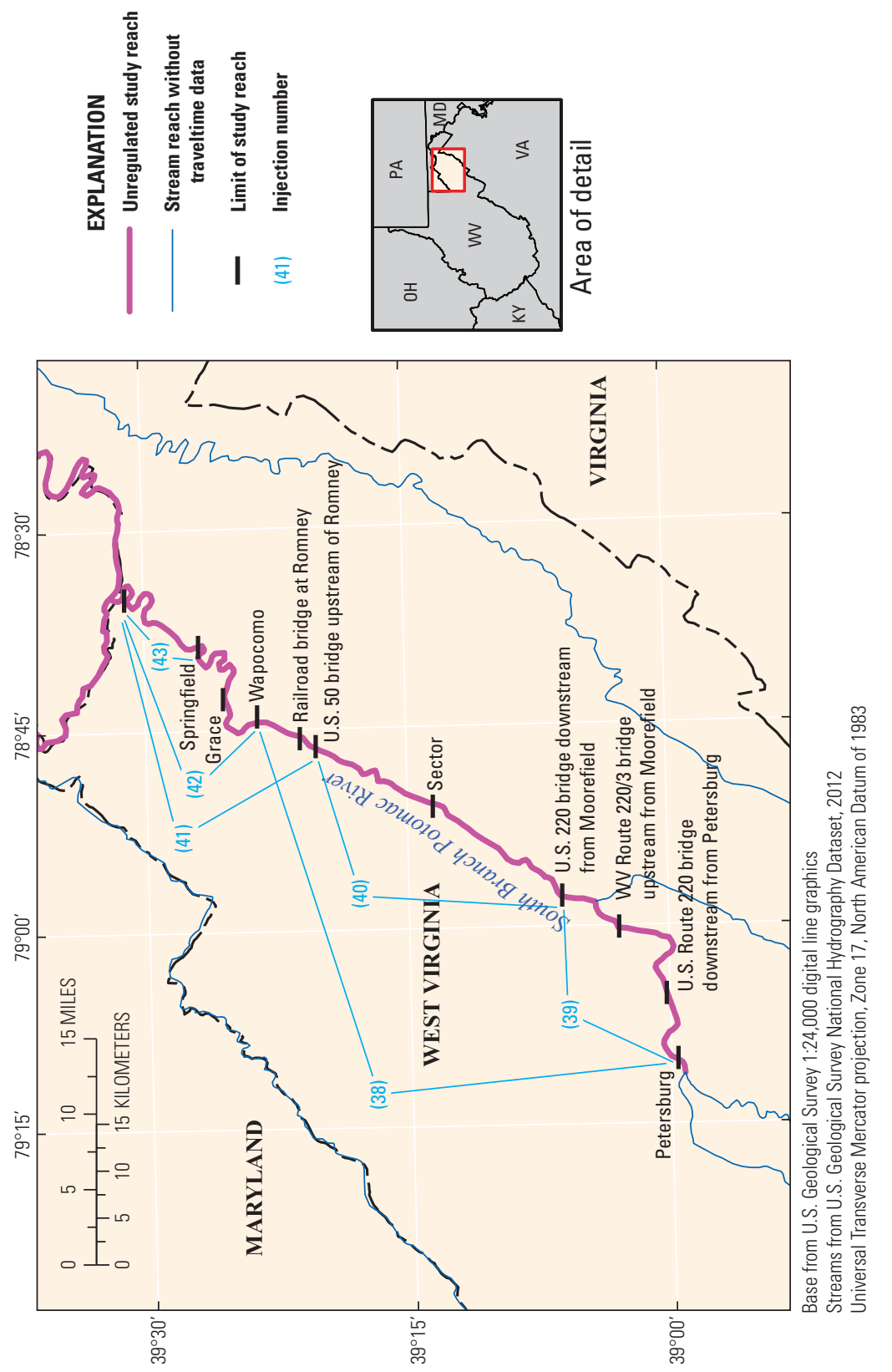


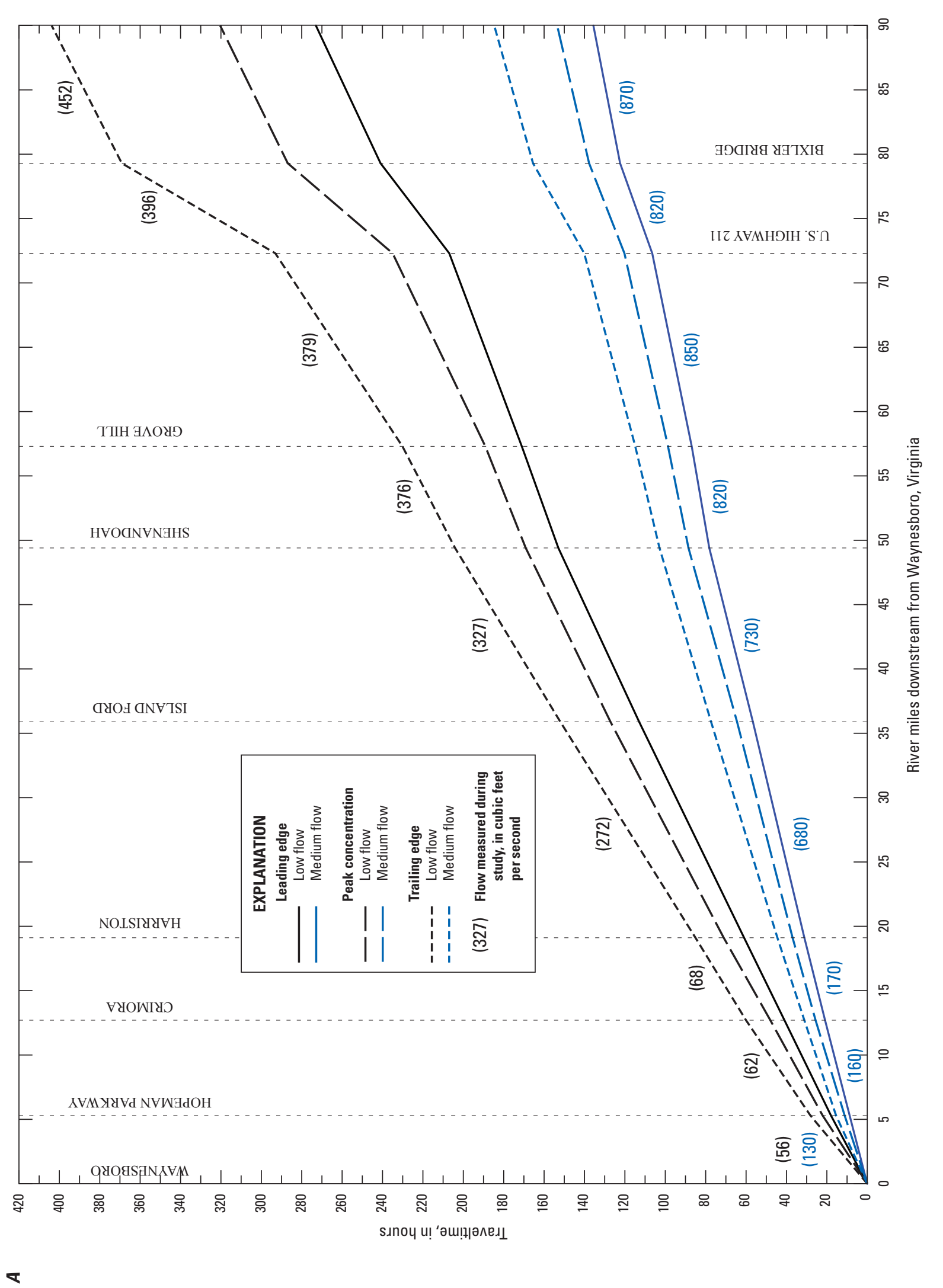




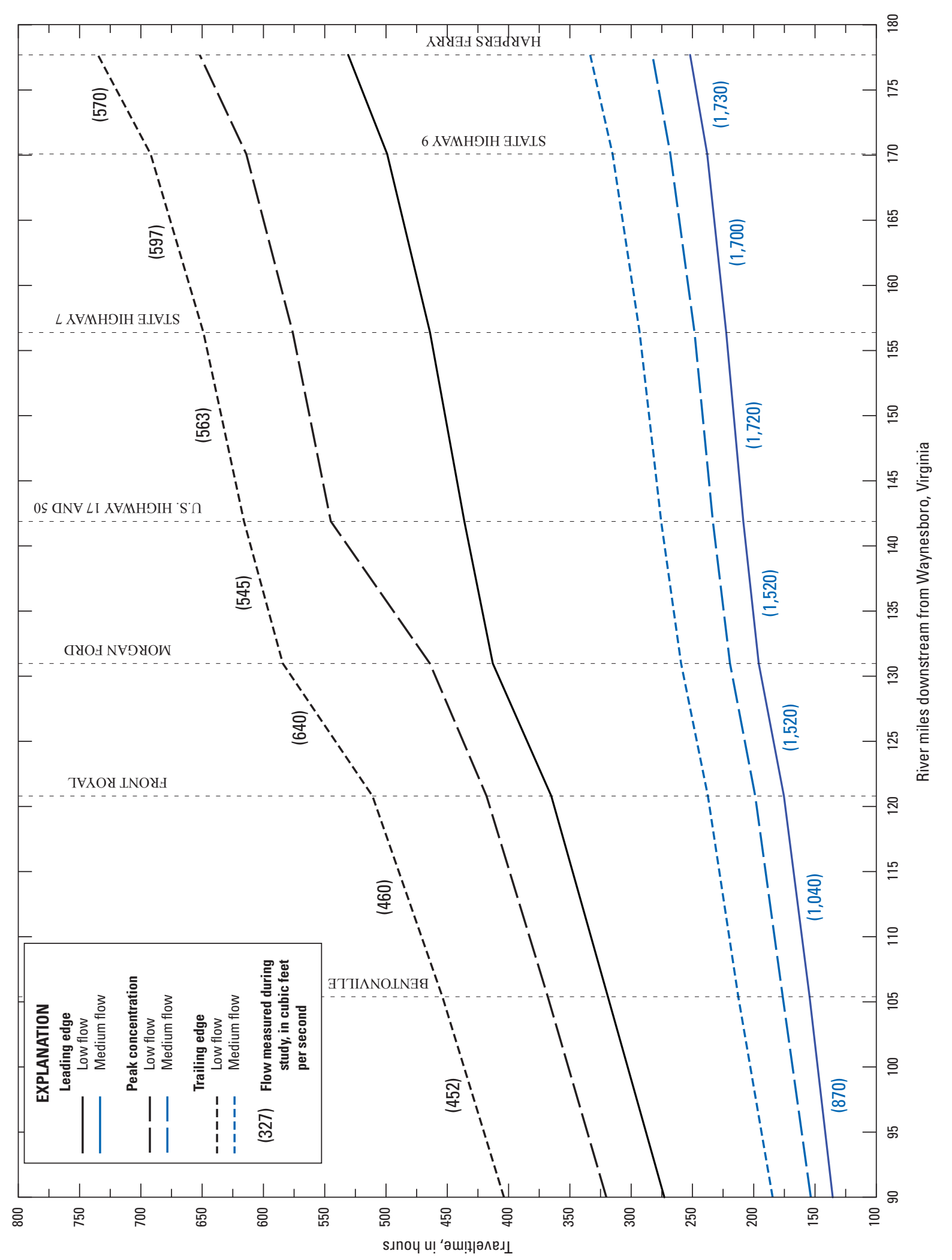

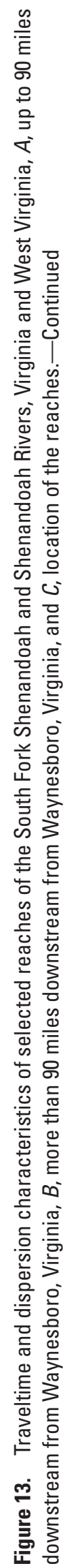



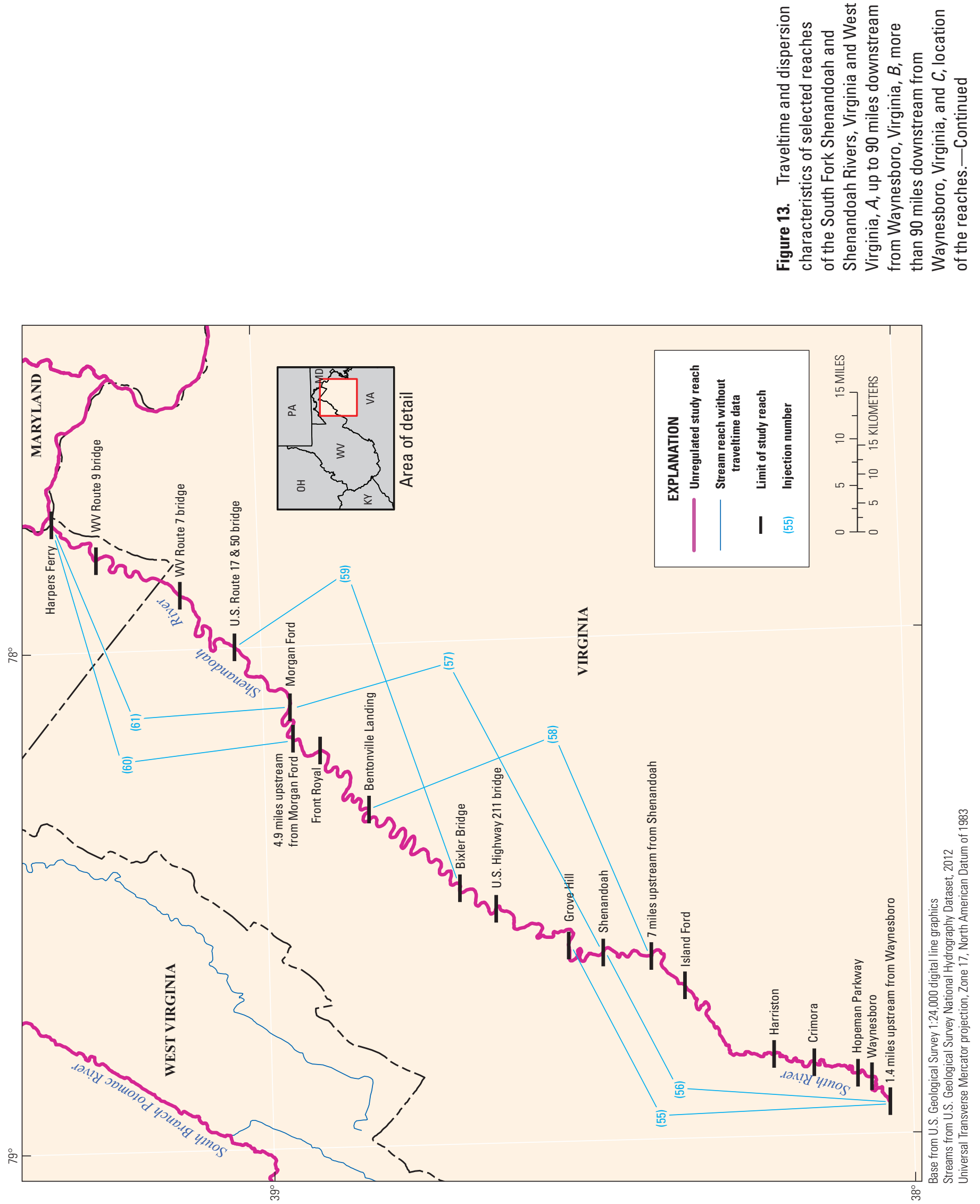


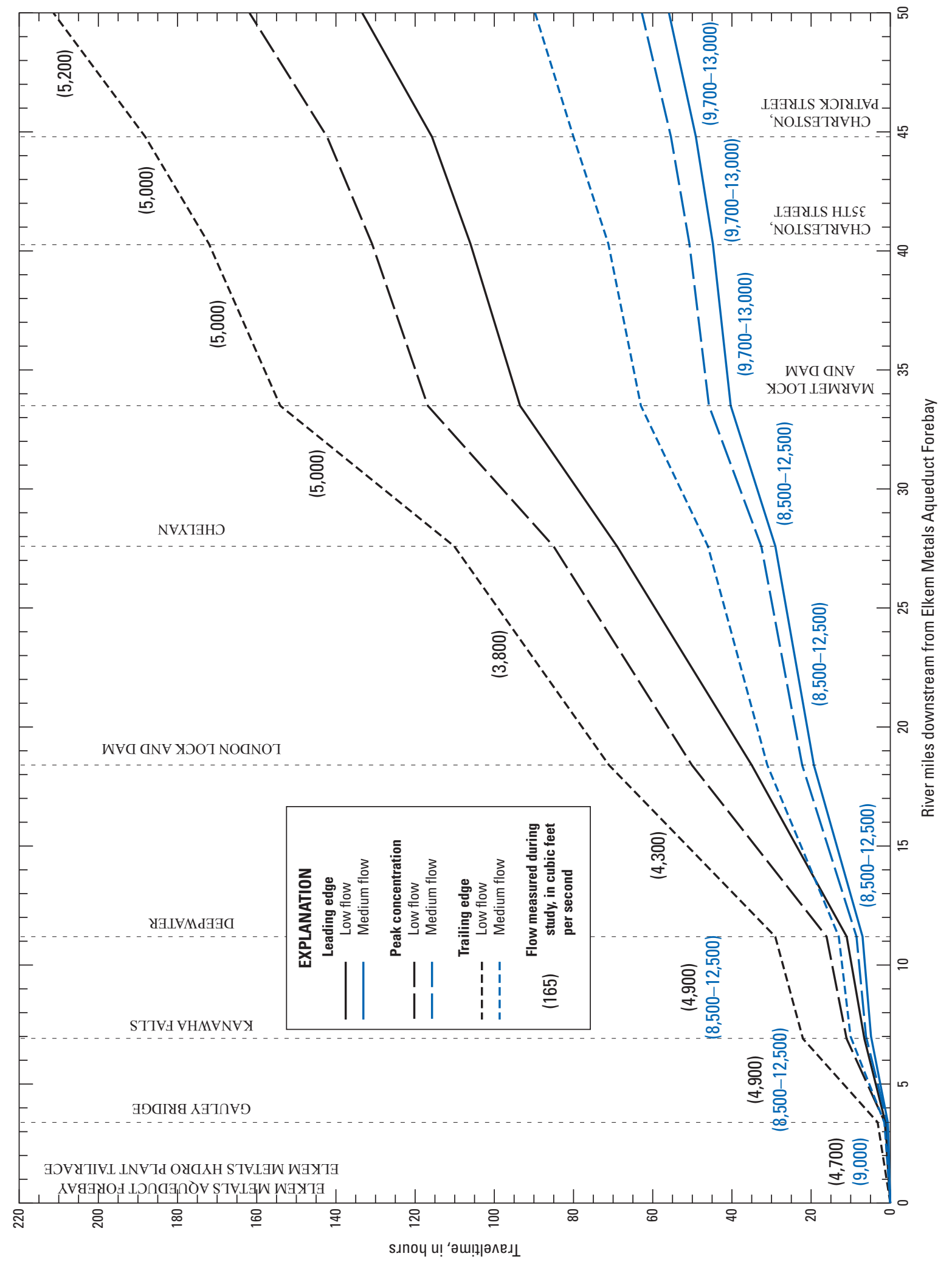




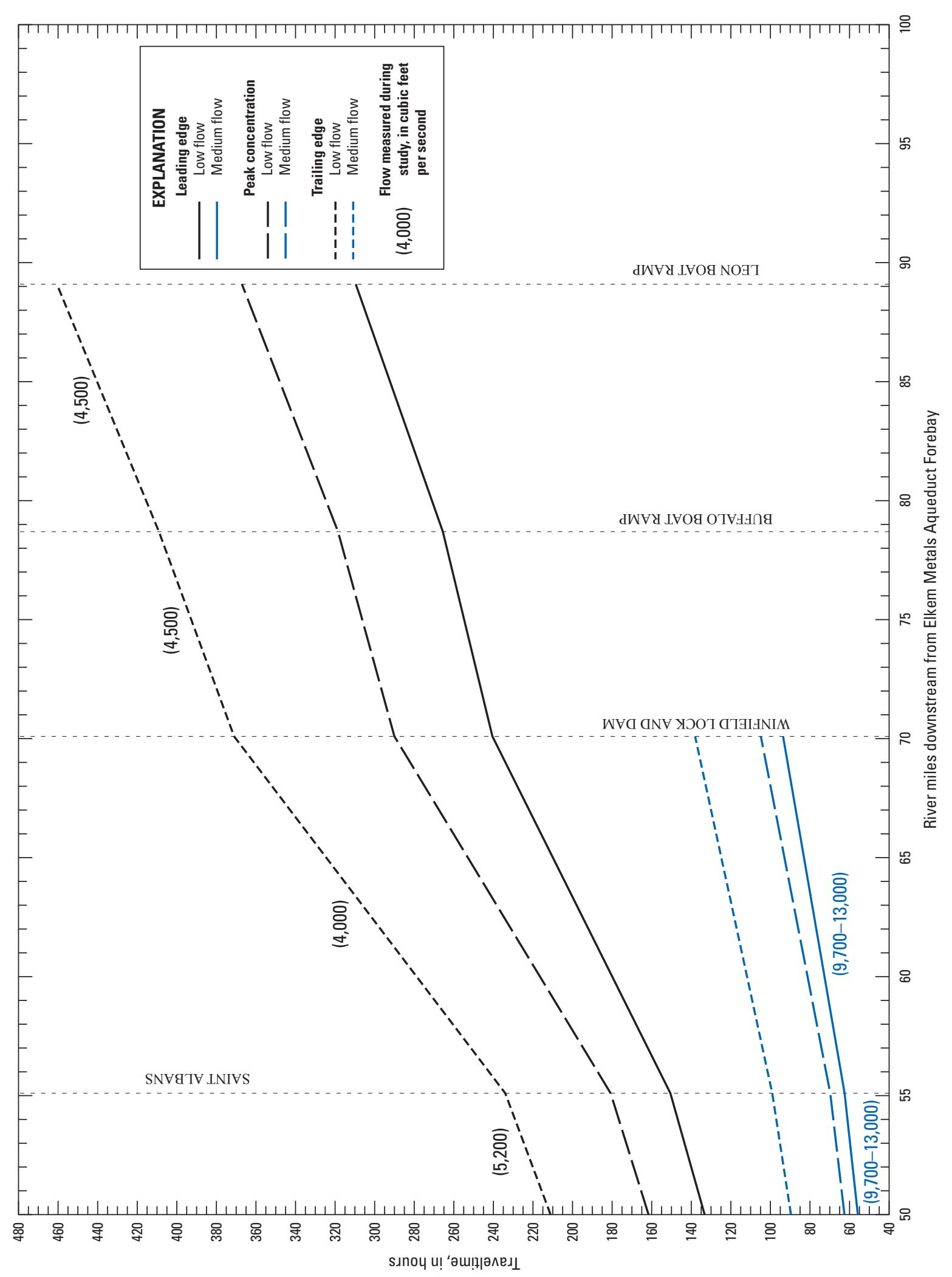

$\infty$ 

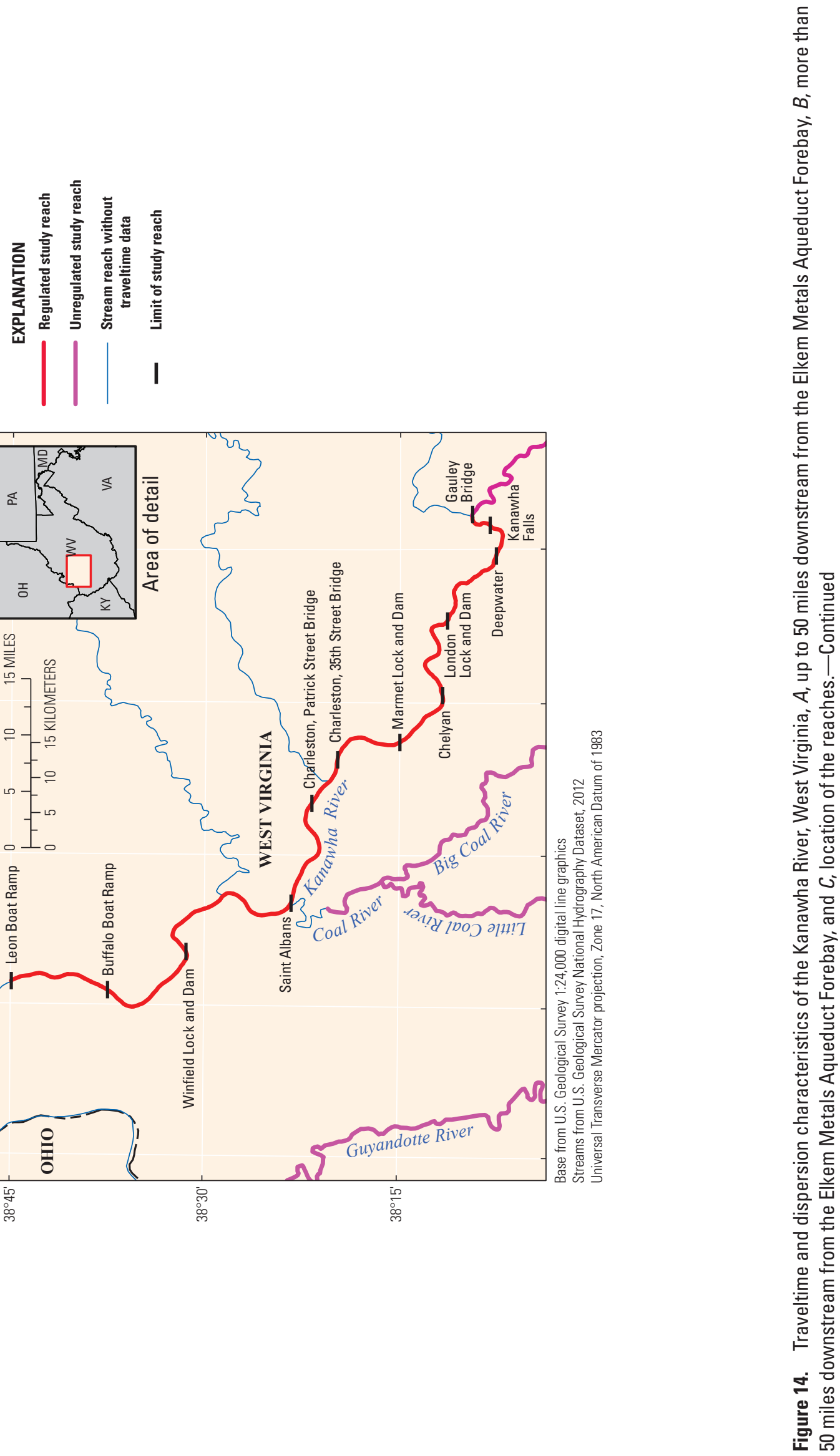


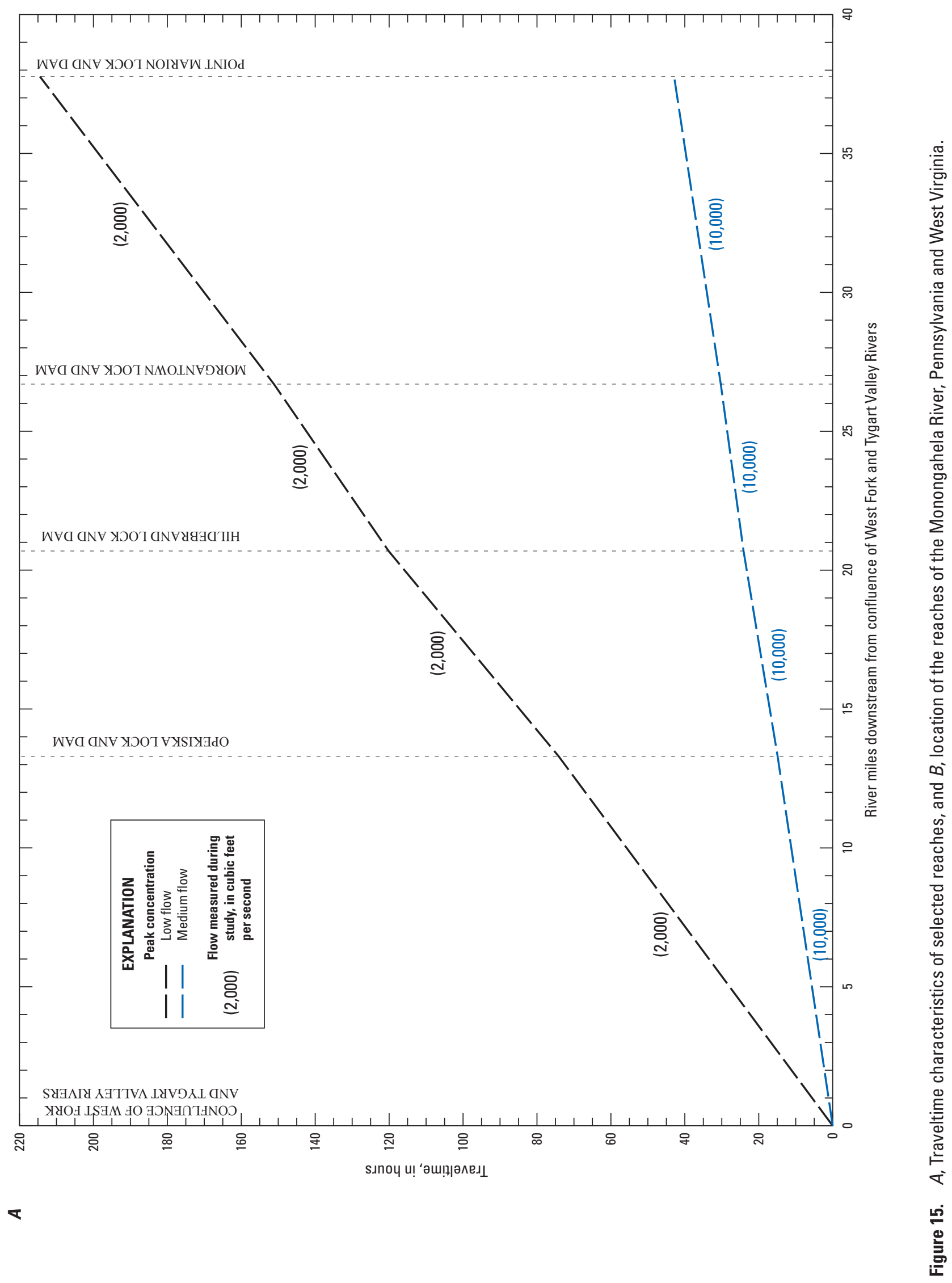




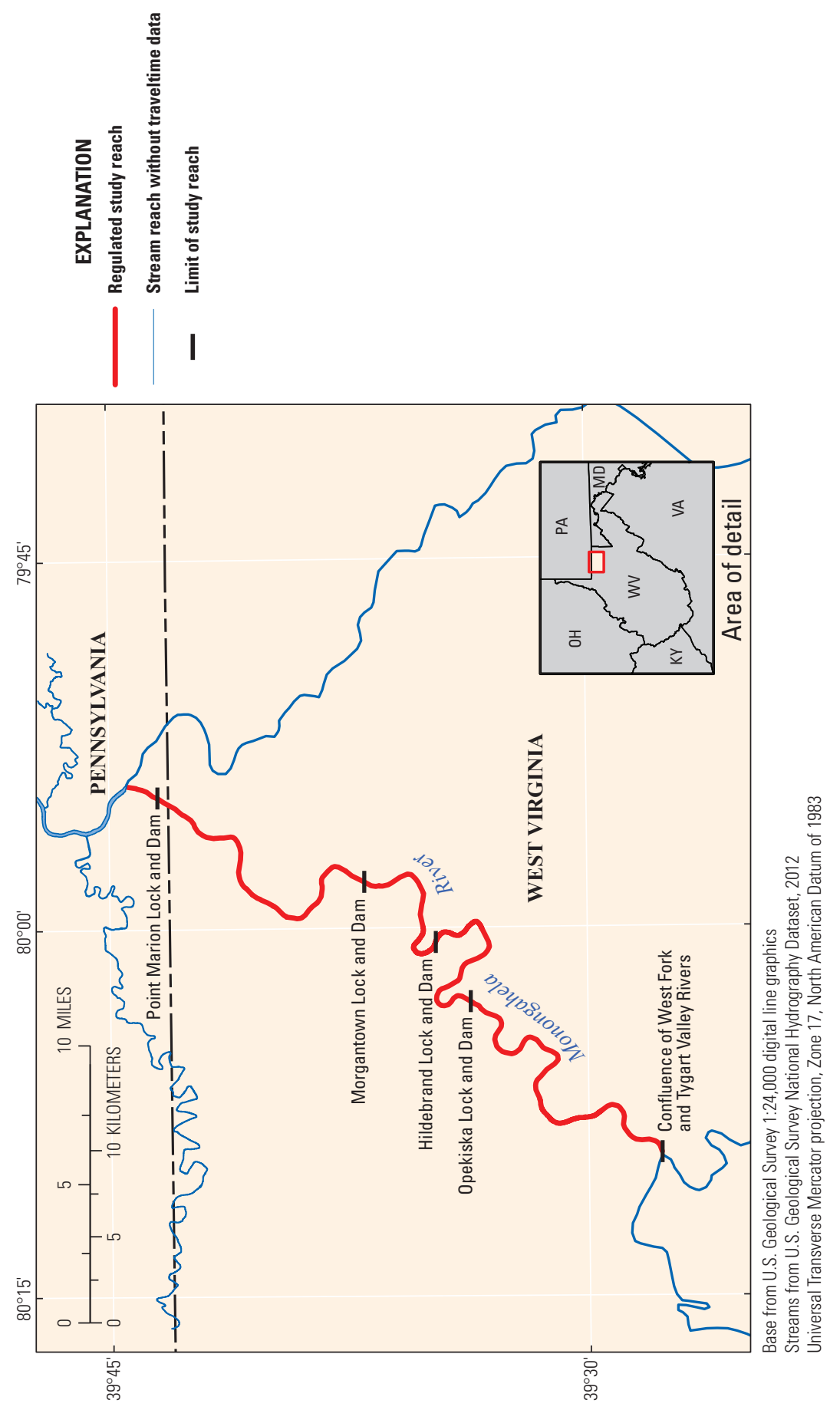










$\infty$ 


\section{Appendix 1: Dye Injection, Traveltime, and Dispersion Data}

The traveltime and dispersion data in tables 1-1 and 1-2 were obtained from reach-specific study documents, compiled by Jobson (1996), U.S. Geological Survey Annual Water Data Reports (http://wdr.water.usgs.gov/), and a summary of waterresources data prepared by Evaldi and others (2009) or were determined from 1:24,000 scale topographic or from the geographic information system interactive map available at $h t t p: / / w w w . m a p w v . g o v /$. The data are presented in two tables containing abbreviated headings. Detailed descriptions of the table headings are provided below.

Inj No is a unique number that identifies each injection.

Stream is the name of the stream where tracer dye was injected.

Location is the stream location where tracer dye was injected.

Date is the date the tracer dye was injected.

Time is the time of the injection in military time, where midnight is $2400 \mathrm{~h}$.

Injection is the amount of tracer dye injected, in either liters (L) or pounds (lb), including the percentage of dye in solution when reported.

Dye type is the type of tracer dye injected.

Mass is the mass of "pure" dye injected, in lb.

Reach is the name that identifies each stream reach where traveltime and dispersion data are tabulated.

$\mathrm{D}_{\mathrm{a}} \quad$ is the drainage area of the stream at the end of the reach, in square miles $\left(\mathrm{mi}^{2}\right)$.

Q is the streamflow at the end of the stream reach (where dye samples were collected), in cubic feet per second $\left(\mathrm{ft}^{3} / \mathrm{s}\right)$.

Len is the length of the stream reach, in miles (mi).

Slope is the slope of the stream reach, dimensionless ( $\mathrm{ft} / \mathrm{ft}, \mathrm{mi} / \mathrm{mi}$, or kilometers per kilometers $(\mathrm{km} / \mathrm{km})$ ).

$\mathrm{Q}_{\mathrm{a}} \quad$ is the mean annual streamflow at the end of the stream reach, in $\mathrm{ft}^{3} / \mathrm{s}$.

$\mathrm{T}_{1} \quad$ is the traveltime of the leading edge of the dye cloud since injection, in hours (h).

$T_{p} \quad$ is the traveltime of the peak concentration of the dye cloud since injection, in $h$.

$\mathrm{T}_{t}$ is the traveltime of the trailing edge of the dye cloud (defined as when the concentration recedes to 10-percent of the peak concentration) since injection, in $\mathrm{h}$.

$\mathrm{T}_{\mathrm{d}} 10 \quad$ is the time of passage of the dye cloud $(\mathrm{Td} 10=\mathrm{Tl}-\mathrm{Tt})$, in $\mathrm{h}$.

$\mathrm{C}_{\mathrm{p}}$ is the observed peak concentration of the dye cloud collected at the end of the stream reach, in micrograms per liter $(\mu \mathrm{g} / \mathrm{L})$.

$\mathrm{R}_{\mathrm{r}}$ is the recovery ratio, equal to the mass of rhodamine dye injected divided by the mass recovered, unitless.

$\operatorname{Cup}_{\mathrm{H}} \quad$ is the unit peak concentration defined by Hubbard and others (1982), in $(\mu \mathrm{g} / \mathrm{L})\left(\mathrm{ft}^{3} / \mathrm{s}\right) / \mathrm{lb}$.

$\mathrm{C}_{\text {up }} \quad$ is the unit peak concentration defined by Jobson (1996), in 1/s (inverse seconds). 


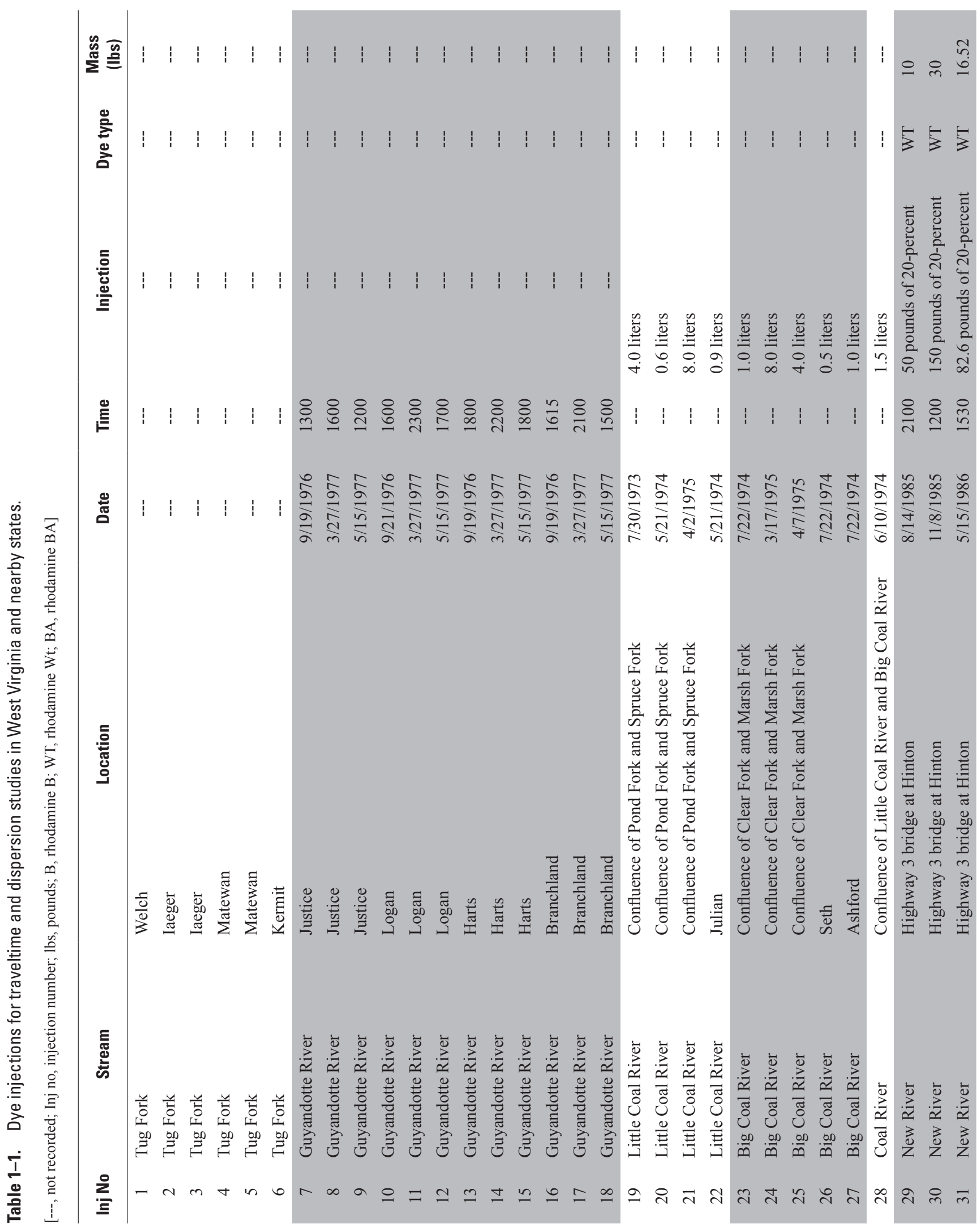




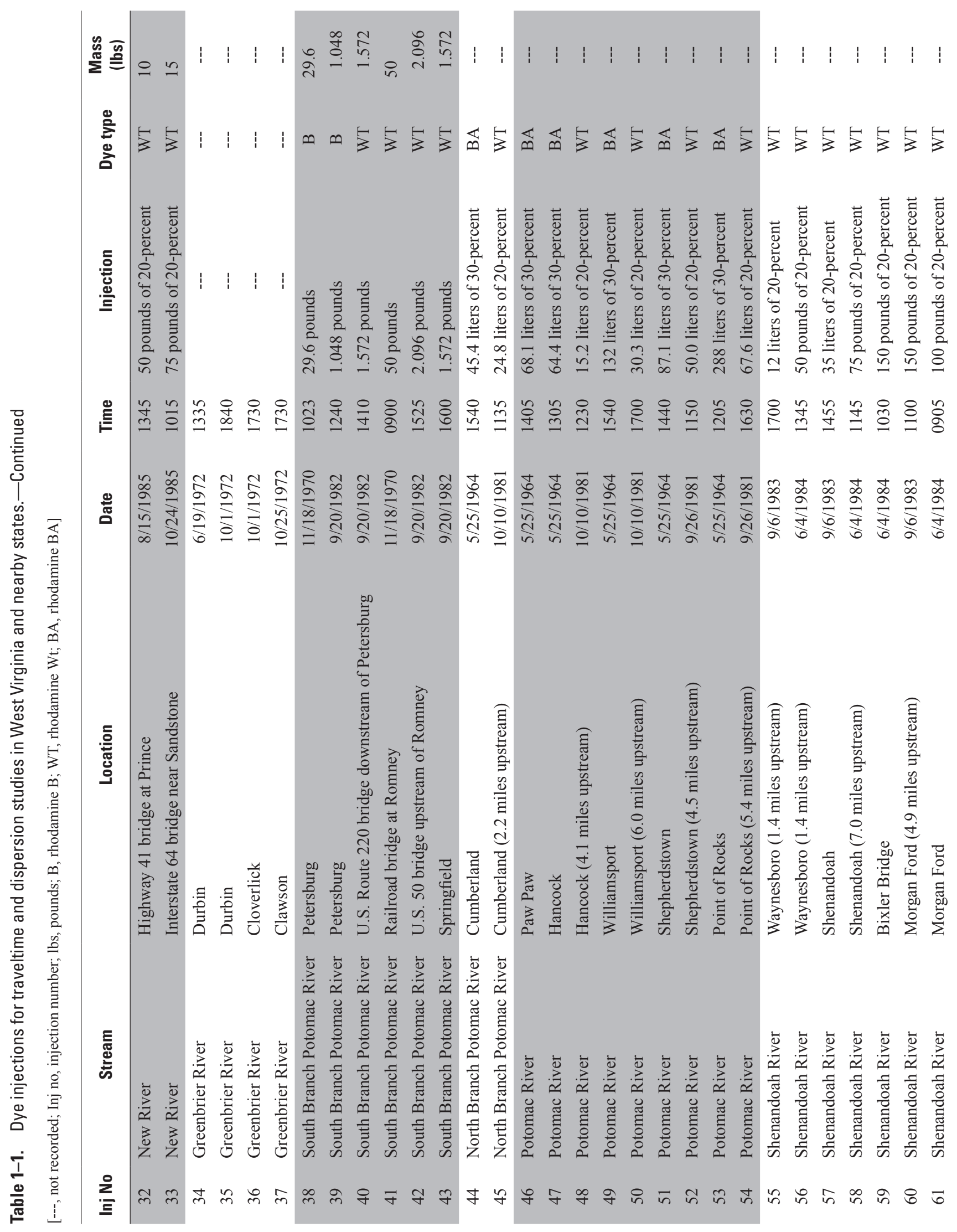




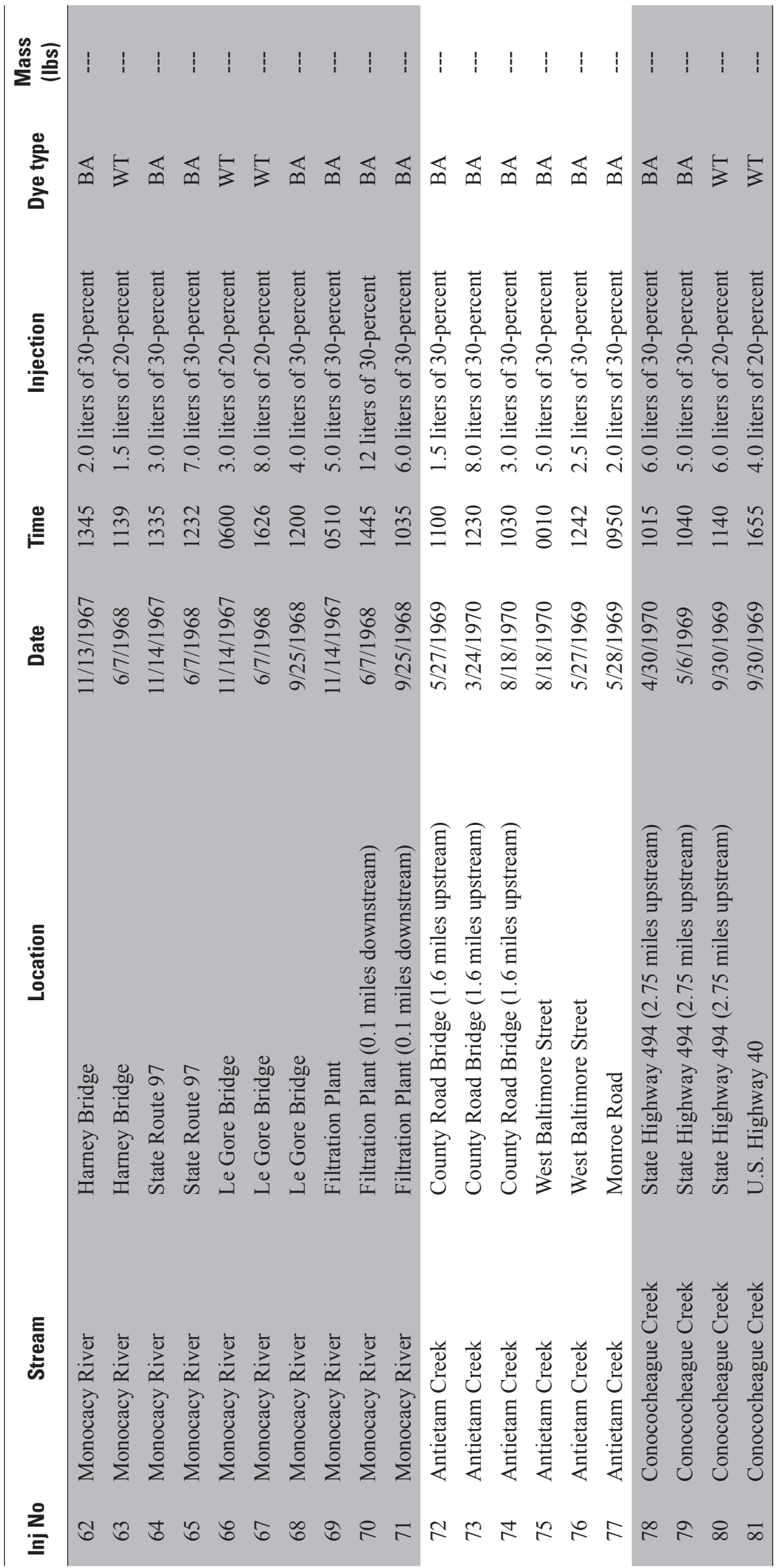




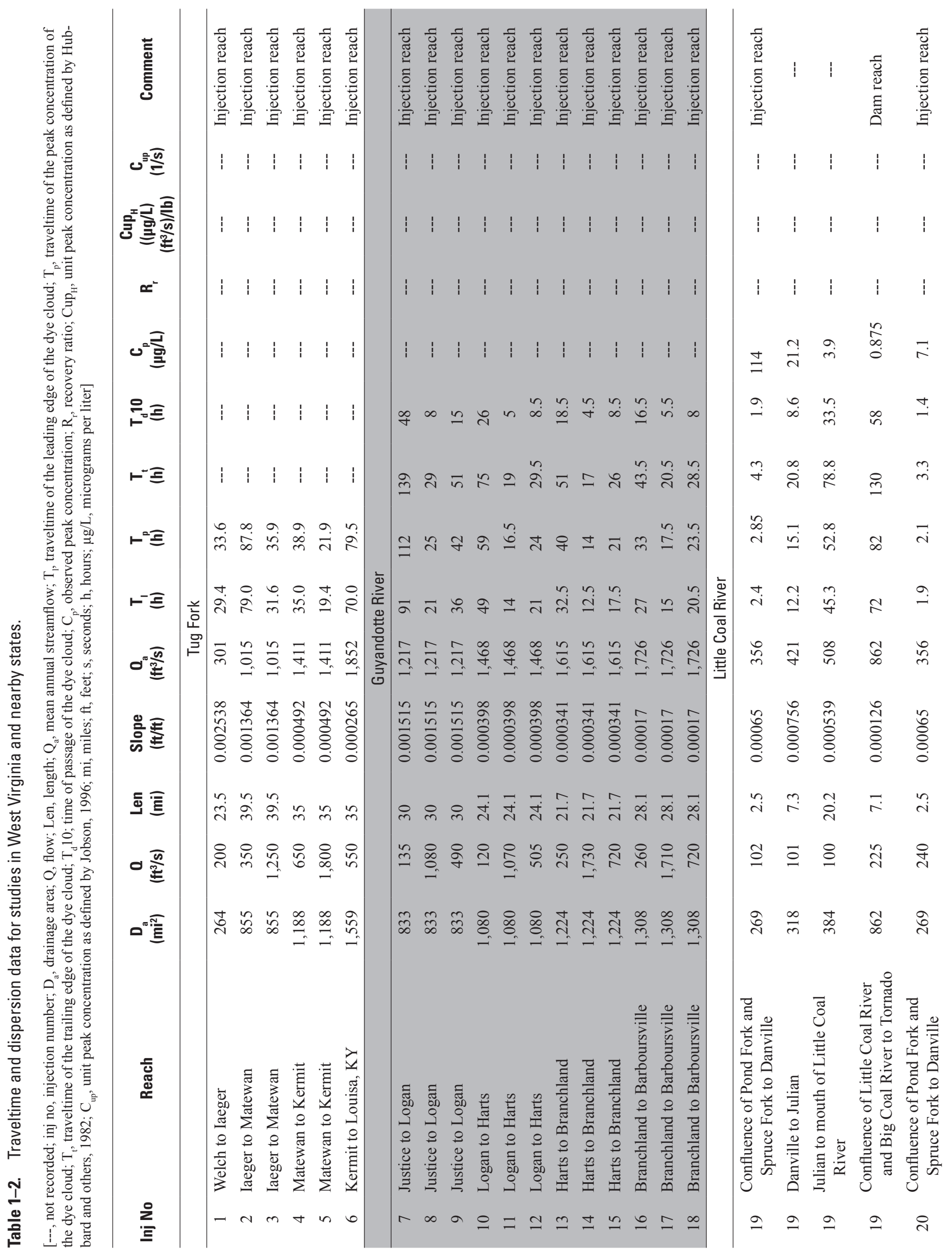




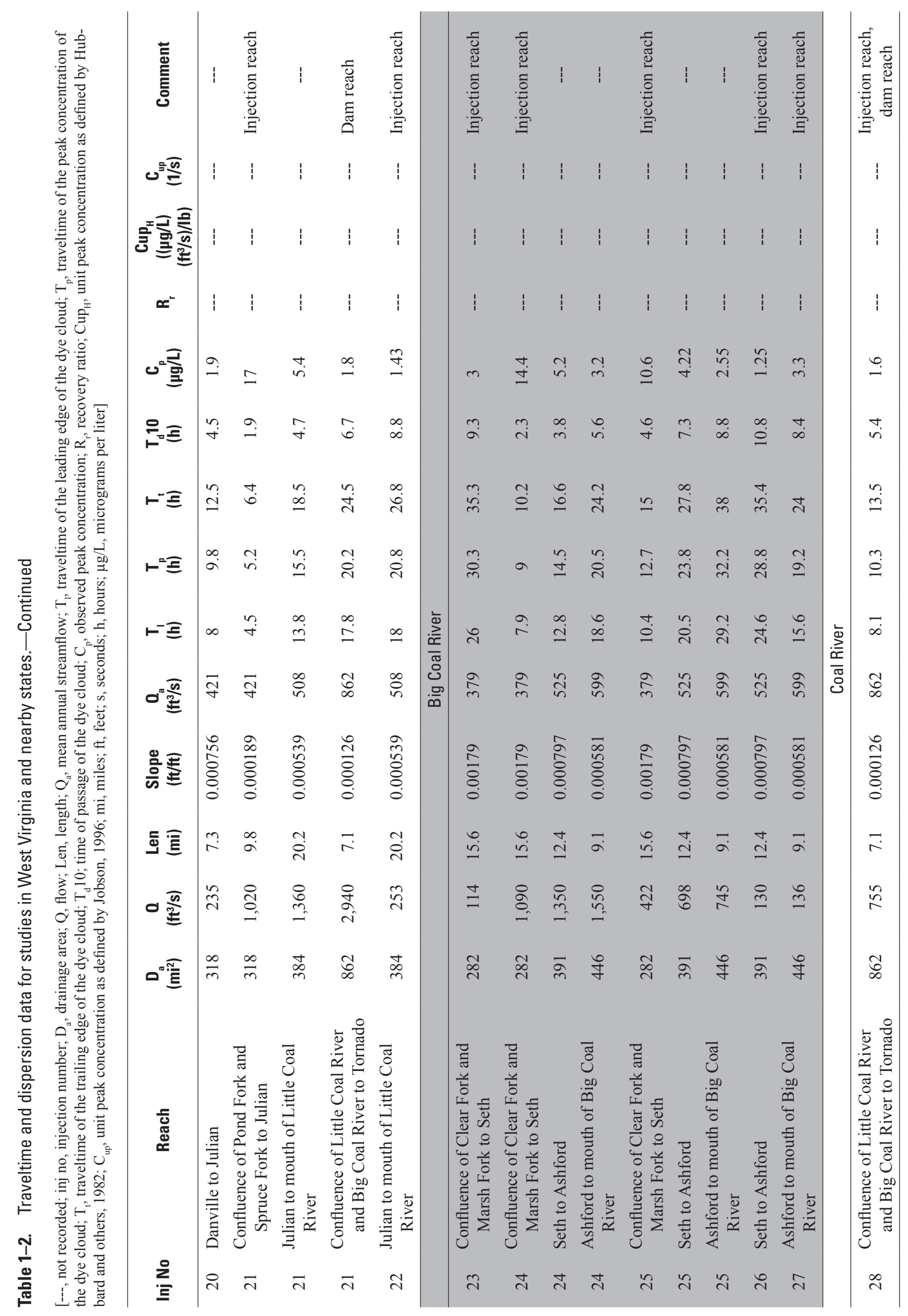




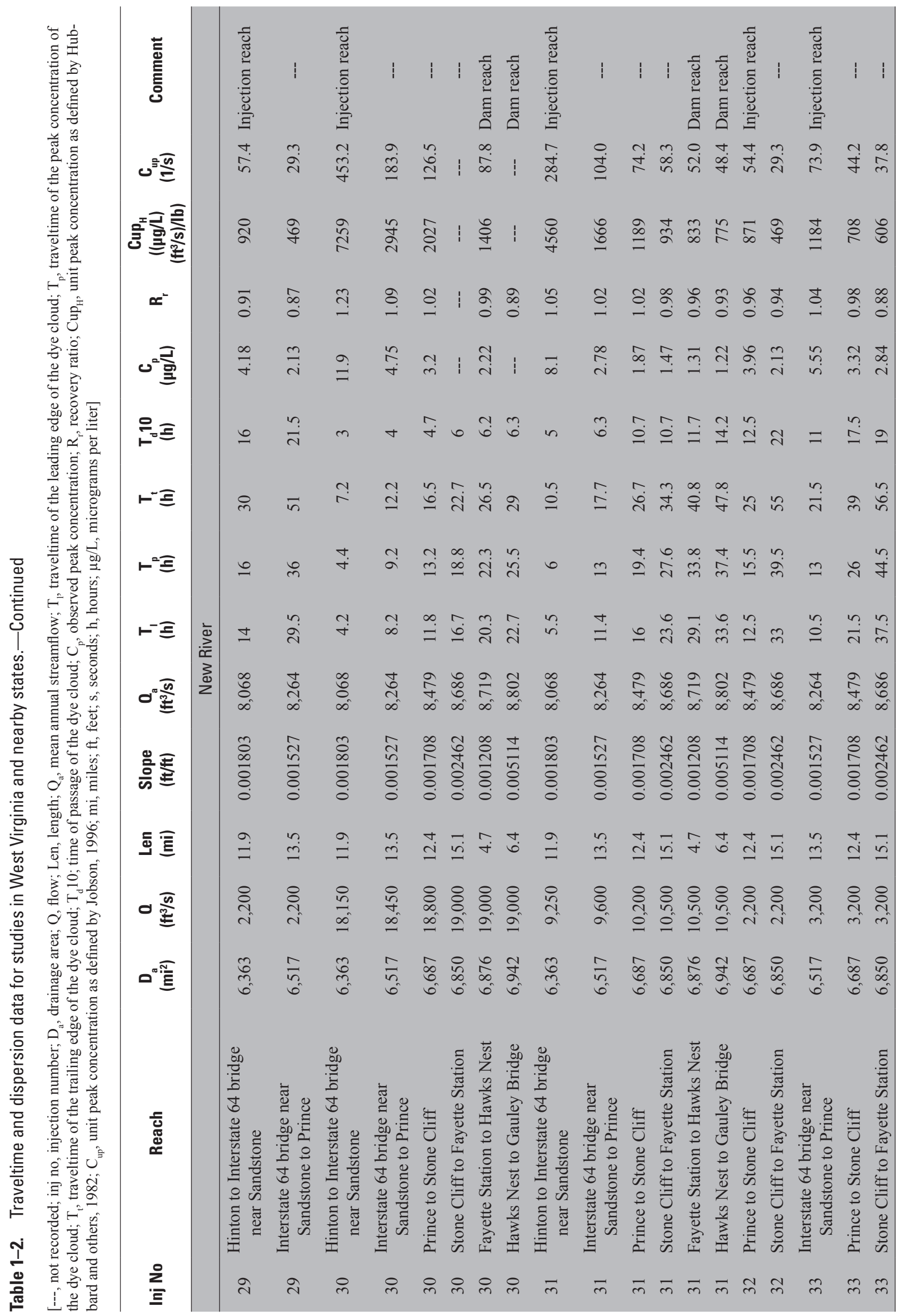




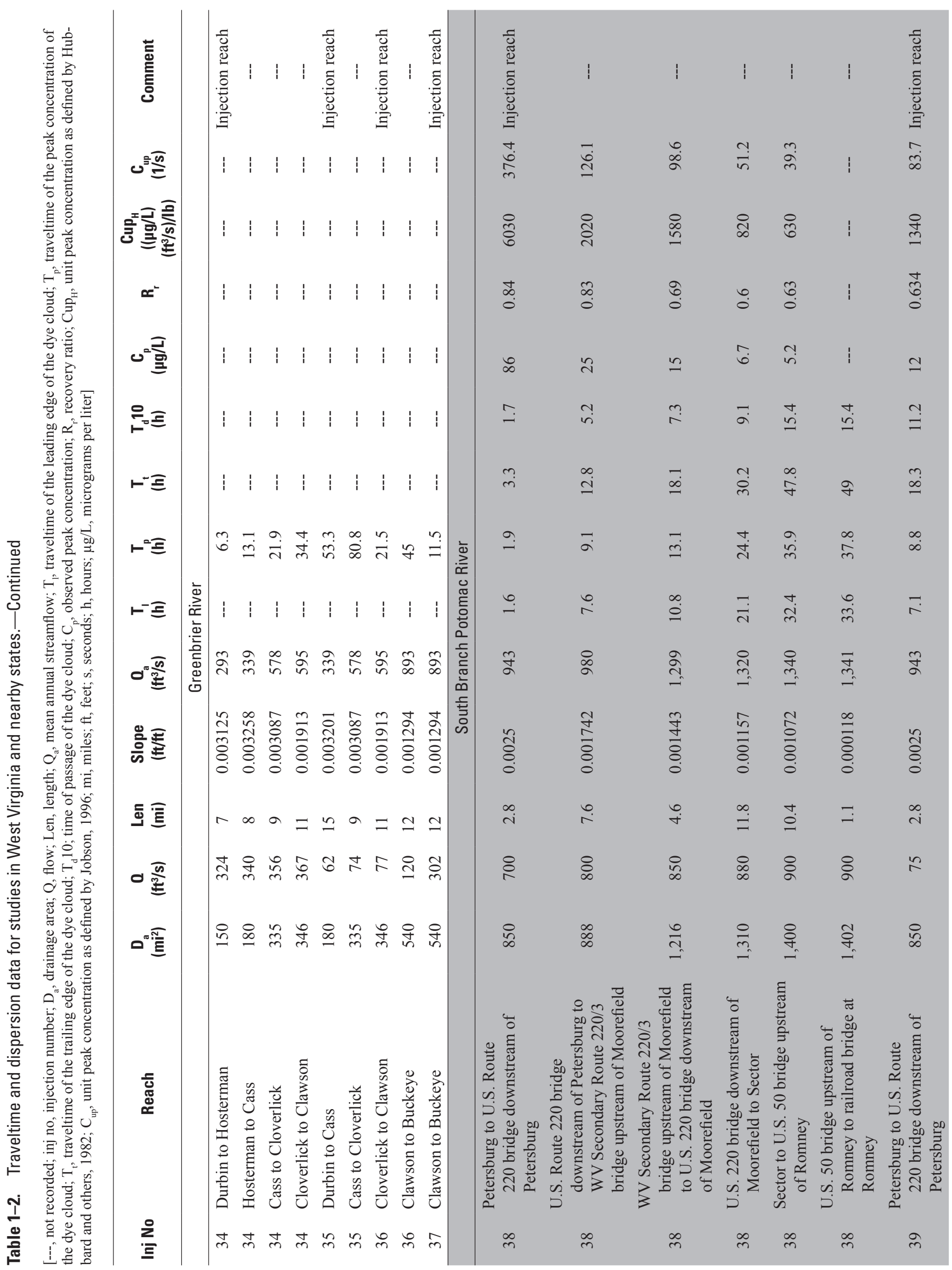




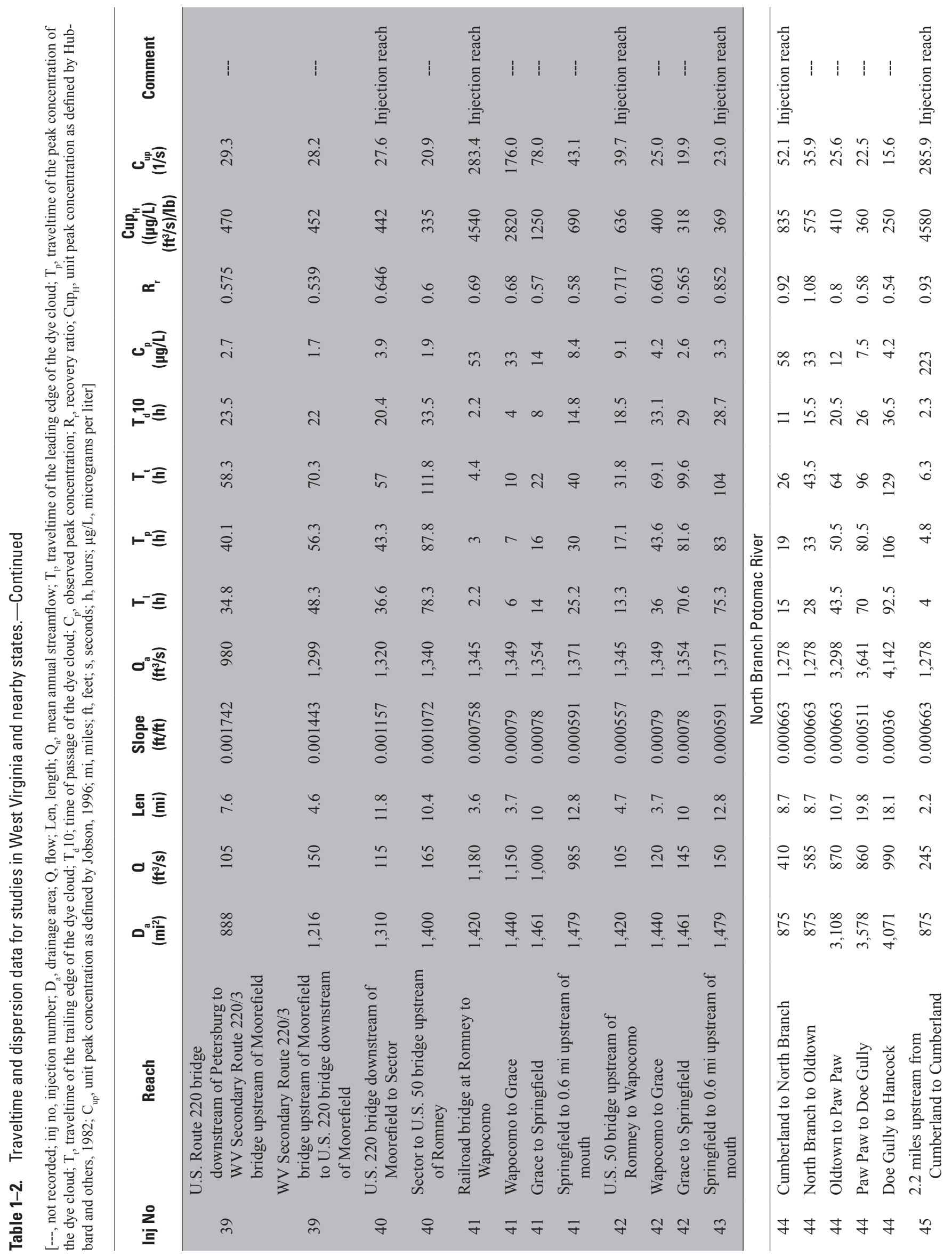




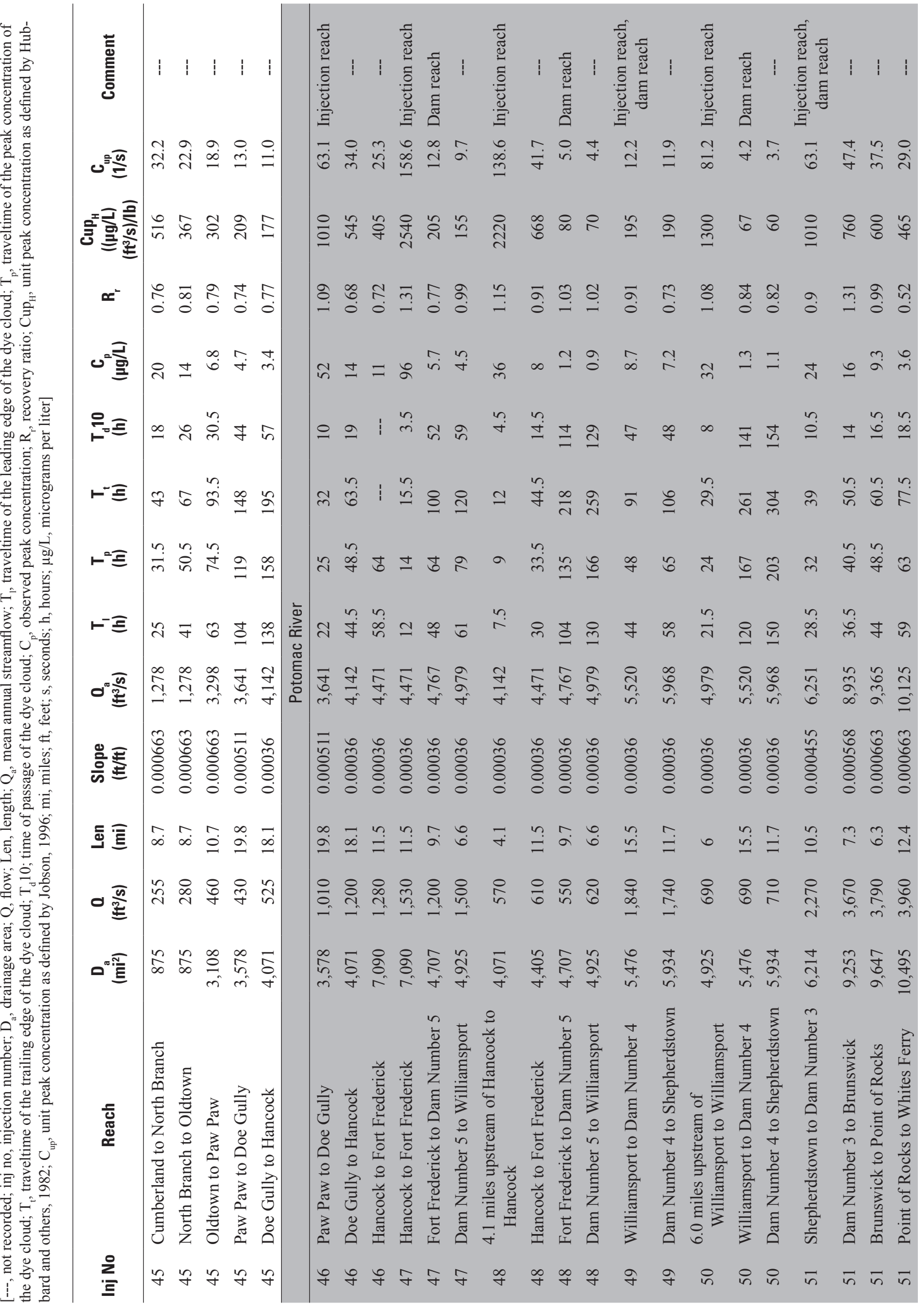




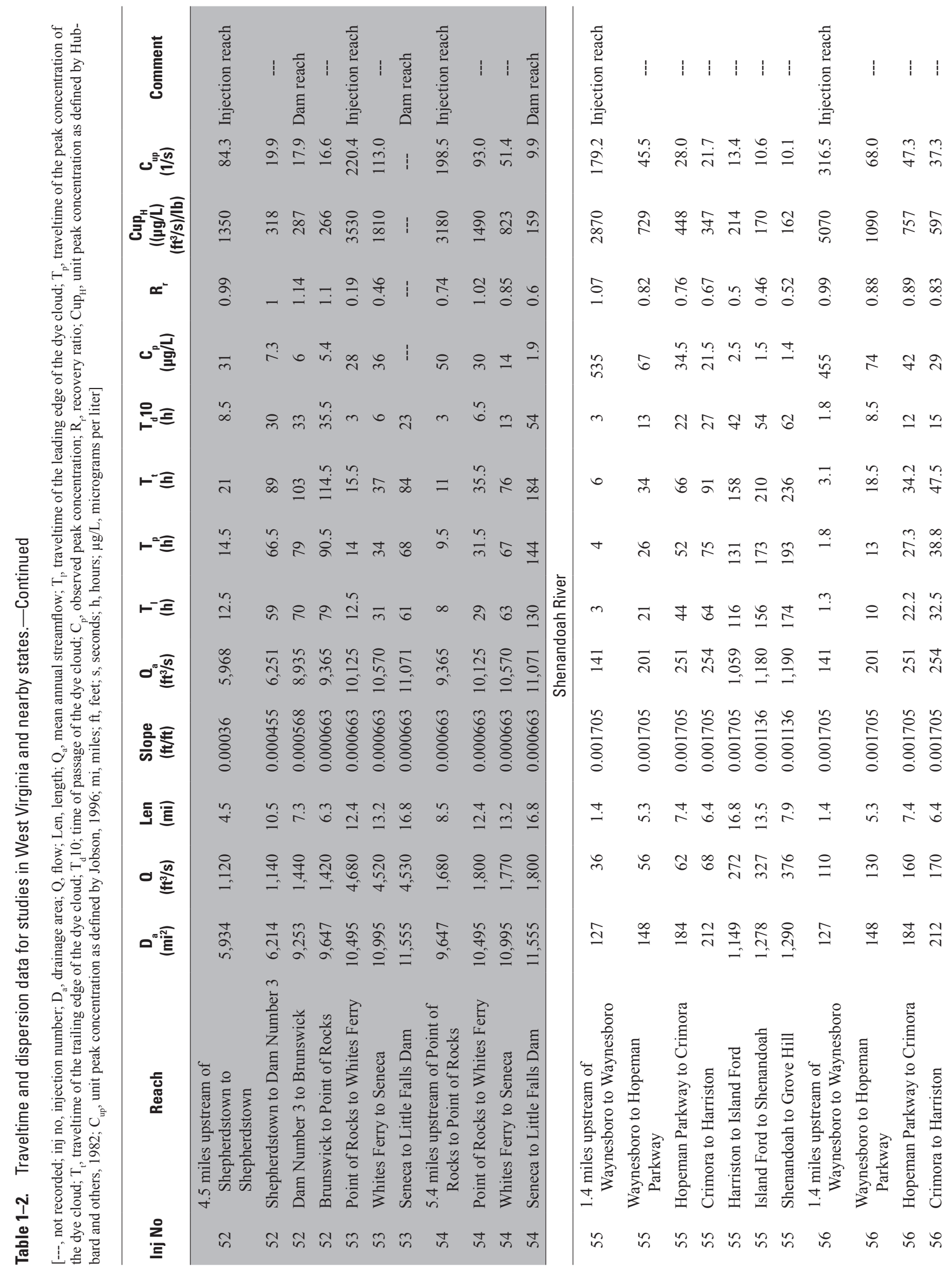




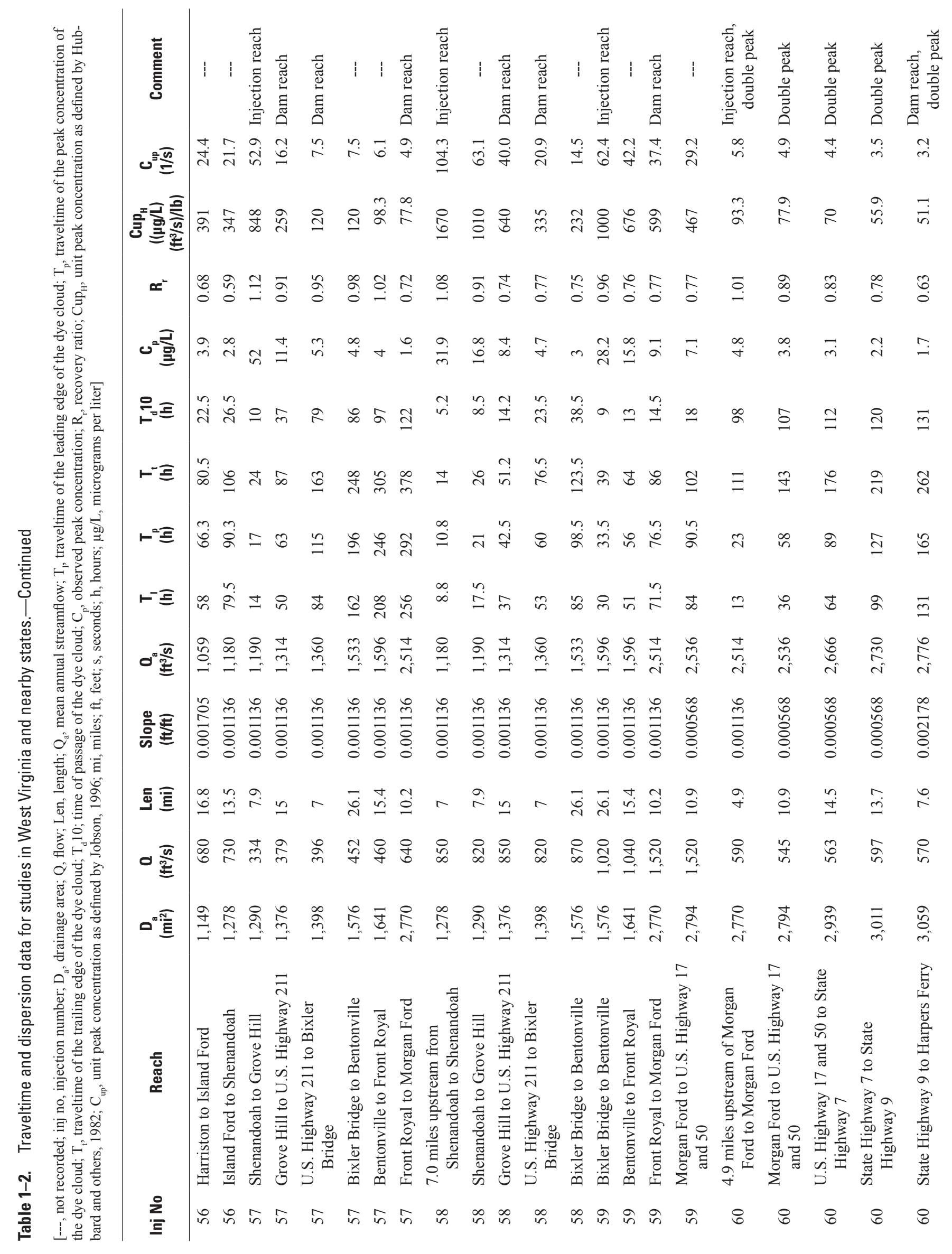




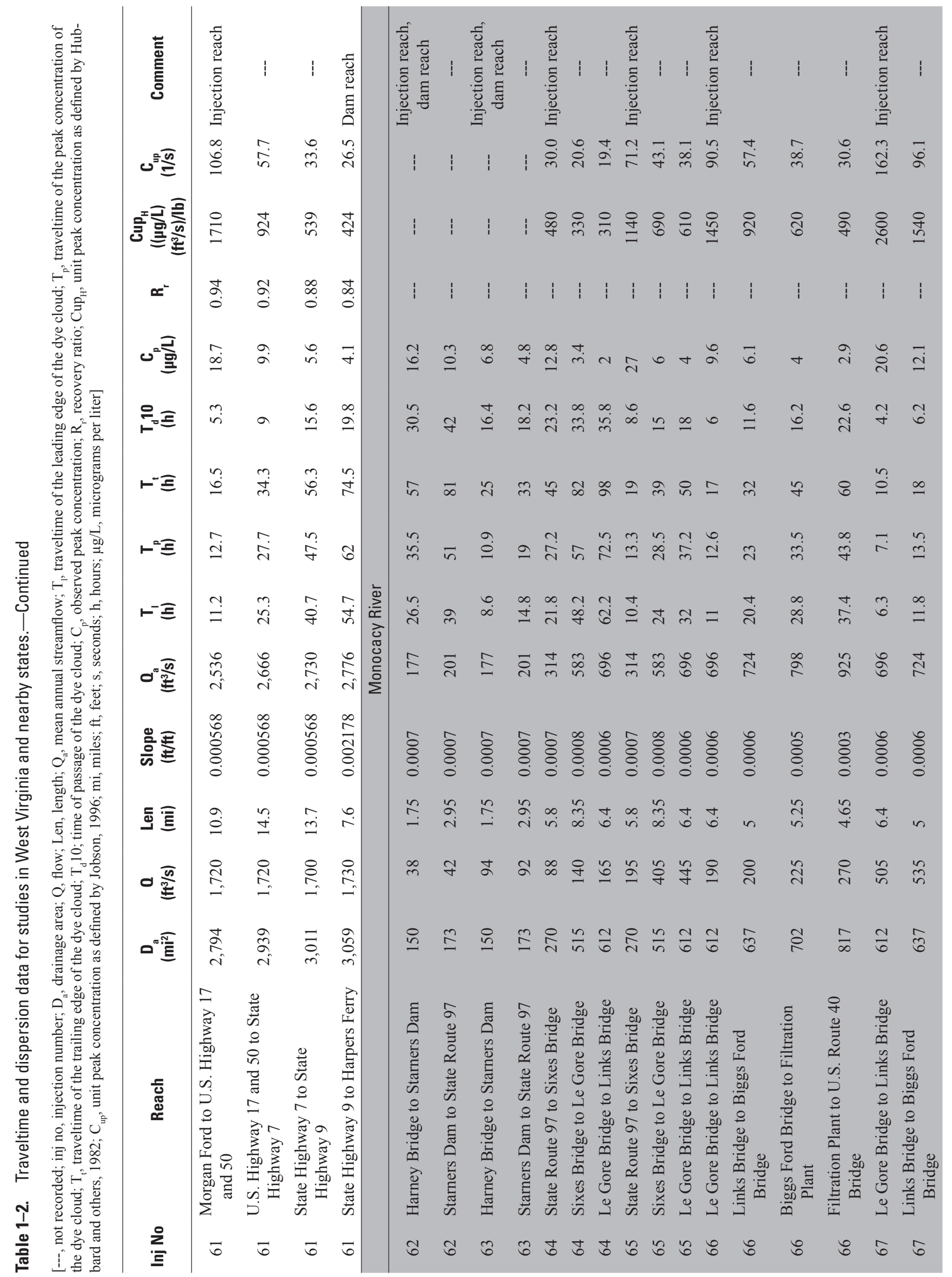




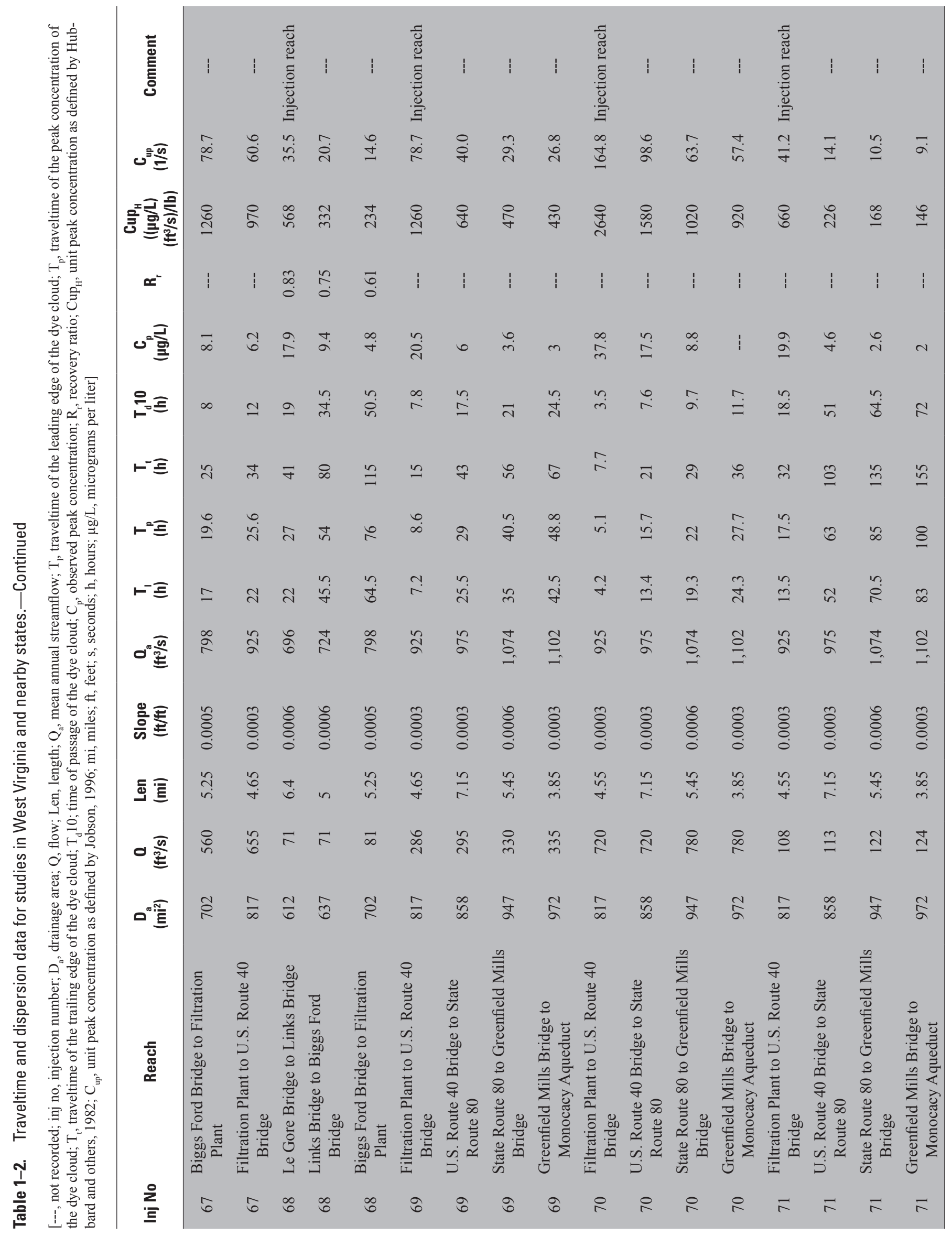




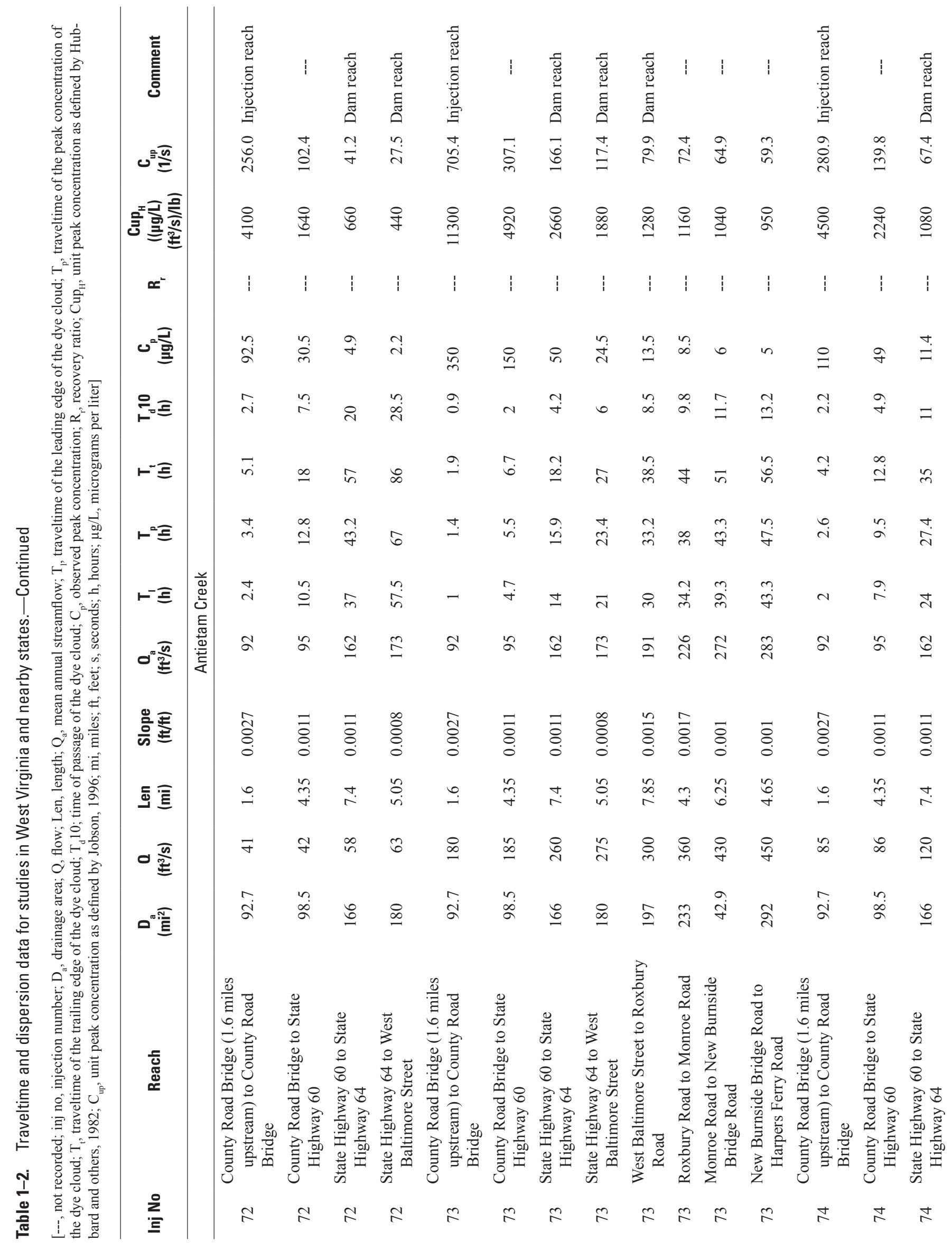




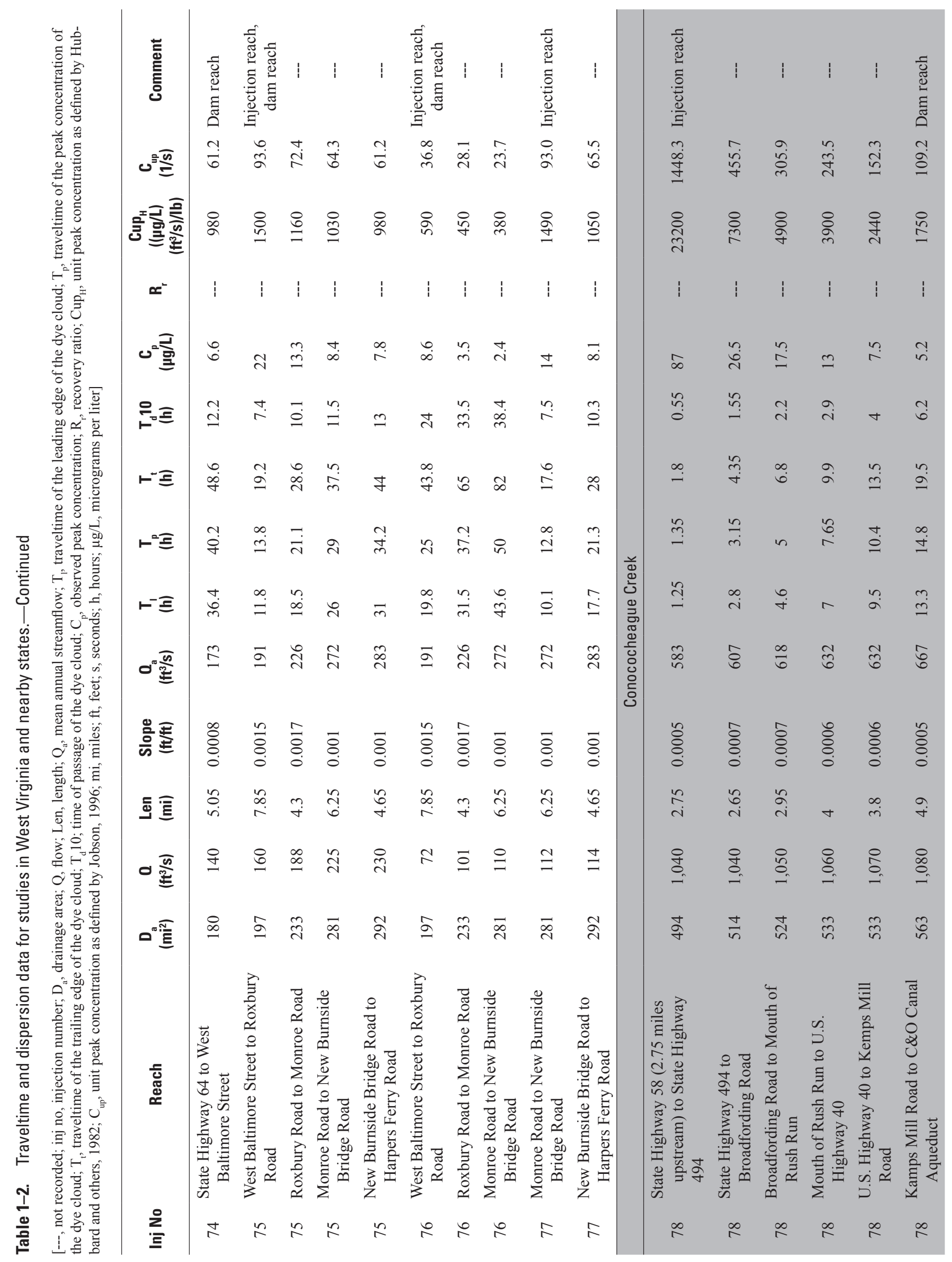




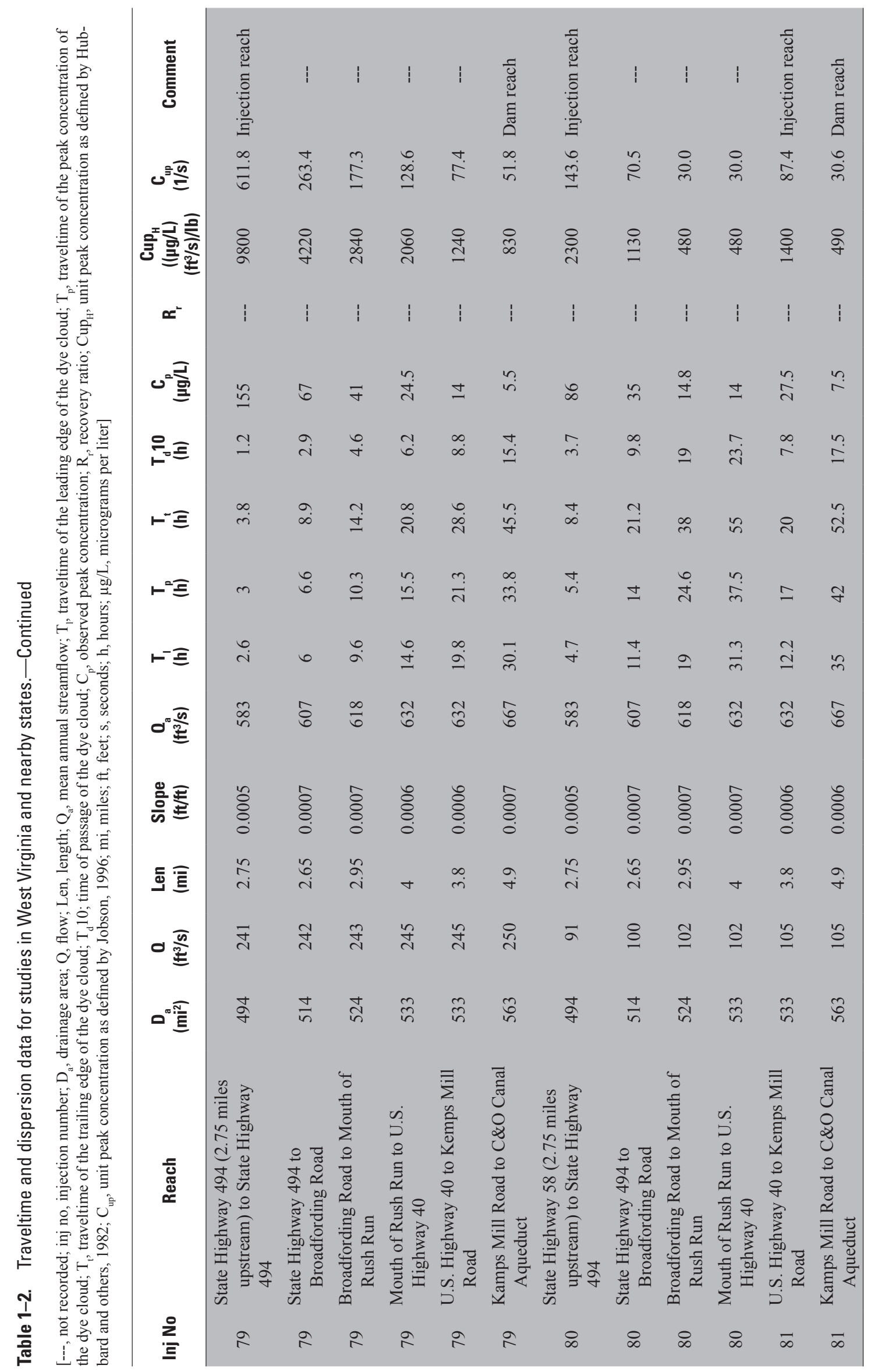



For additional information call or write to:

Director, U.S. Geological Survey

West Virginia Water Science Center

11 Dunbar Street, Charleston, WV 25301

(304) 347-5130

http://wv.usgs.gov 
